\title{
Memory and Control: Mylasa and the Sanctuary of Zeus Labraundos
}

Mylasa is situated in inland Karia (Figure 3.1), a mountainous region known primarily for its hilltop settlements and sanctuaries until it underwent a wave of urbanization in the fourth century BC. The Hekatomnids, the local dynasty chosen to rule Karia as satraps under the Achaemenid empire, conducted an intensive reorganization of the region that included the foundation of cities and the monumentalization of key sanctuaries. Mylasa was home to the Hekatomnids and hence one of the first to benefit from their legacy. The polis remained a major center in the region for generations to come.

With its rich sacred landscape, Mylasa provides an excellent starting point for this study. By the first century BC, Strabo writes of Mylasa and its sanctuaries:

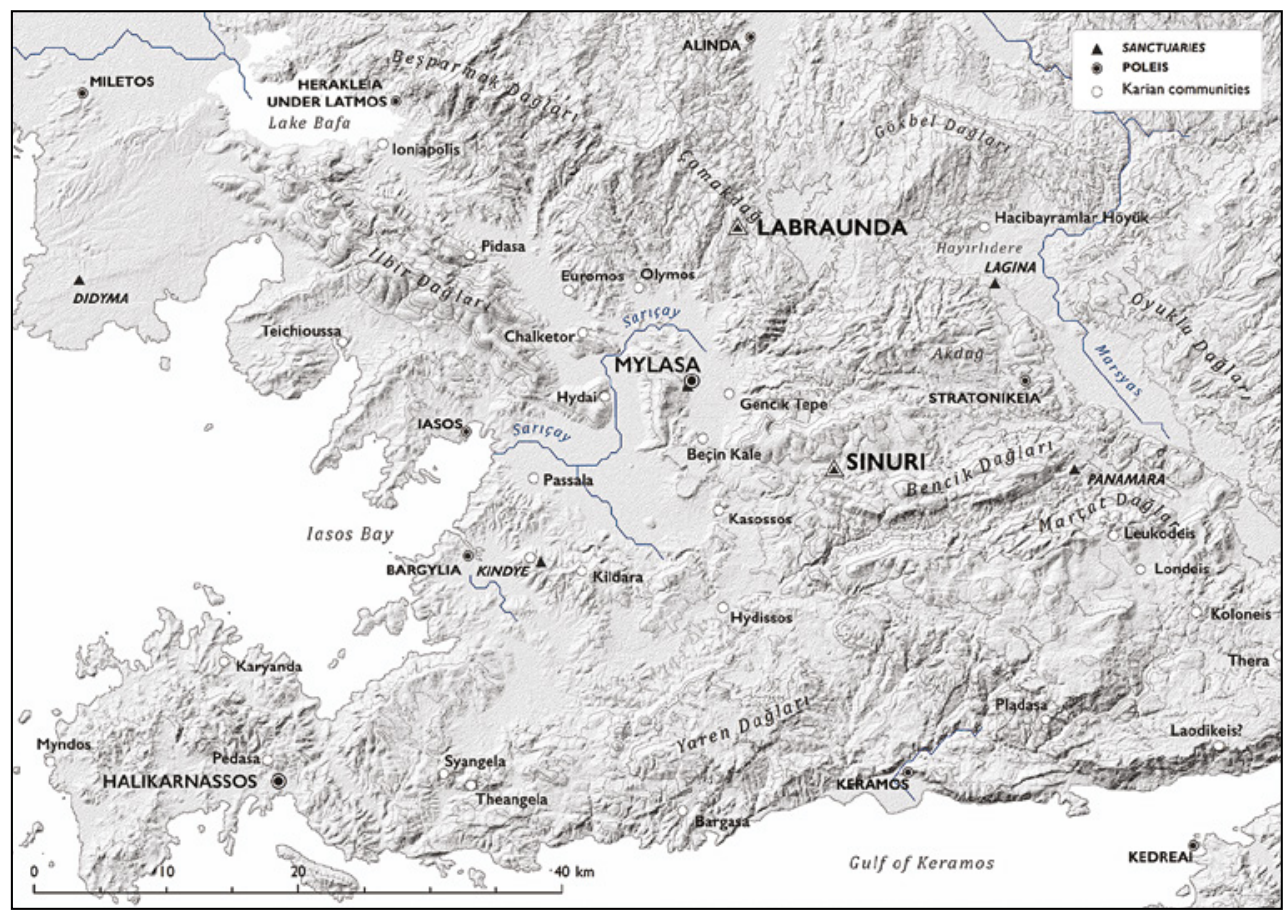

FIGURE 3.1 Map locating Mylasa and the shrines of Zeus Labraundos and Sinuri

(C) CHRISTINA G. WILliAMSON, 2021 | DOI:10.1163/9789004461277_004

This is an open access chapter distributed under the terms of the CC BY-NC 4 . 
... the Mylasians have two temples of Zeus, Zeus Osogo, as he is called, and Zeus Labrandenus. The former is in the city, whereas Labranda is a village far from the city, being situated on the mountain near the pass that leads over from Alabanda to Mylasa. At Labranda there is an ancient shrine and statue of Zeus Stratios. It is honored by the people all about and by the Mylasians; and there is a paved road of almost sixty stadia from the shrine to Mylasa, called the Sacred Way, on which their sacred processions are conducted. The priestly offices are held by the most distinguished of the citizens, always for life. Now these temples belong peculiarly to the city; but there is a third temple, that of the Karian Zeus, which is a common possession of all Karians, and in which, as brothers, both Lydians and Mysians have a share. It is related that Mylasa was a mere village in ancient times, but that it was the native land and royal residence of the Karians of the house of Hekatomnos. ${ }^{1}$

Strabo communicated to his readers the principal sanctuaries associated with Mylasa of his day. The sanctuary of Zeus Osogollis, ${ }^{2}$ mentioned first, was probably the chief sanctuary of Mylasa by the late first century вс. Located 'in the city', as Strabo emphasizes, it had a strong role in the rural economy of the polis, as several inscriptions testify. ${ }^{3}$ The sanctuary of Zeus at Labraunda, 'far from the city', is located in the hills some 14 kilometers to the north, and was one of the most significant construction projects of the Hekatomnids in the mid-fourth century BC. Strabo remarks that both sanctuaries 'belong peculiarly to the city', juxtaposing them with a third sanctuary, that of Karian Zeus, which was the regional center of the Karian federation; its whereabouts, however, have yet to be identified. ${ }^{4}$

1 Strabo 14.2.23 (transl. H.L. Jones (1929) The geography of Strabo, LCL 223).

2 On the name of Osogollis, rather than Osogo or Osogoa, see Blümel (1990). This unusual maritime Zeus, or Zenoposeidon, is discussed in Parker (2017), 94-95.

3 See below on the land-lease contracts of the sanctuary of Zeus Osogollis. The sanctuary has been identified in the modern town of Milas by the stretch of polygonal wall that may have defined part of its terrace, Laumonier (1958), 105, and Hauvette-Besnault and Dubois (1881), 98. Based on Machon's description of the sanctuary of Zeus Osogollis (here called Zenoposeidon) as before the gates ( $\pi$ ò $\tau \hat{\omega} \nu \pi v \lambda \hat{\omega} \nu)$, (Gow Machon Fr.8 (=Ath.viII.337c), lines 55-56), Laumonier locates it outside but near the walls, Laumonier (1958), 105. Mylasa, however, had no walls (Rumscheid (1999b)) and given its proximity to the town center as well as Strabo's description, the sanctuary of Zeus Osogollis is here considered an 'urban' sanctuary, although it may well have been at the edge of town, connecting it with the plain to the south and towards Beçin Kale.

4 This was once considered to be at Uzunyuva, the large platform with the single column on the Hisarbaşı hill in Milas, e.g. Laumonier (1958), 43; Bean (1971 [1989]), 22; Voigtländer (1991). 
Archaeological investigations have revealed at least three more sanctuaries in the territory of Mylasa that Strabo does not mention: a sanctuary for a goddess at Kale Mevkii, between Mylasa and Labraunda; ${ }^{5}$ a more monumental sanctuary to an unknown deity at Gencik Tepe, roughly three kilometers east of town (Figure 3.10); ${ }^{6}$ and the sanctuary of the Karian god Sinuri, some 15 kilometers southeast of the urban center (Figure 3.1). Like Labraunda, this last shrine was also extensively remodeled and terraced by the Hekatomnids. The sanctuary at Gencik Tepe seems to have undergone a renewal in the late third or early second centuries BC, but despite its monumentality, not enough is known about its cult, organization or community to include it in this study; the same is true of the cult place at Kale Mevkii. The sanctuary of Sinuri, however, has been extensively documented and shows close ties to Mylasa that will further be addressed in the Chapter 4.

The sanctuaries of Zeus Labraundos and Sinuri were both targeted for benefactions by the Hekatomnids, yet a very different relationship with Hellenistic Mylasa developed with each shrine. Labraunda, which still stood symbol for Karia, was important for the political and regional identity of the Mylasans, but it became contested space. The sanctuary of Sinuri, on the other hand, was fixed on a subdivision of the citizen population, yet one that changed identity and was subsumed by the polis in the Hellenistic period. This chapter opens with a general historical overview of Mylasa, that also forms the backdrop to Chapter 4, then proceeds to Labraunda as the first case study to be assessed using the framework of analysis set out in Chapter 2. The framework will allow us to systematically examine the many complex changes that took place to each cult in the transfer of power from the Hekatomnid satraps to the democratic polis. After these detailed analyses, the relationship between city and sanctuary is discussed in each case, focusing on the significance of these shrines to Mylasan community.

Illegal excavations have since shown it to be an unfinished 'proto-Maussolleion', Rumscheid (2010), suggested to have later functioned as the 'sacred agora' in Mylasa, Marek and Zingg (2018), 125-126. Alternative suggestions for the shrine of Zeus Karios include: the unidentified monumental sanctuary at Gencik Tepe, Säve-Söderbergh and Hellström (1997); the stairway and podium inside the castle at Beçin Kale, Baran (2009), 306-311; or even the sanctuary of Zeus Karios at Panamara, Debord (2001b), 31-34, as potential home of the Karian League. The suggestion of Beçin Kale in Cook (1961) is unlikely, and is also suggested to have been a precursor to the Maussolleion, Henry (2013).

5 Rumscheid (2005) mentions marble fragments from the fourth century BC and a relief of a goddess with worshipers, found near the remains of a church.

6 Säve-Söderbergh and Hellström (1997); Radt (1969/70), 170. 
Settled from at least the Late Geometric period, Mylasa was in antiquity considered an ancient Karian center. ${ }^{8}$ As Strabo mentioned, it was the home of Karian Zeus and the hub of the Karian League. Herodotos had already described the sanctuary as common only to the Karians and their kin:

[the Karians] hold that they are the aboriginal dwellers on the mainland and ever bore the name which they bear now; and they point to an ancient shrine of Karian Zeus at Mylasa, whereto Mysians and Lydians, as brethren of the Karians (for Lydus and Mysus, they say, were brothers of Kar) are admitted, but none of any other nation, though they learned to speak the same language as the Karians. ${ }^{9}$

Cult was a vehicle for kinship communities, and an even stronger marker of identity than language. This passage shows how places of cult could create openings across political borders on the one hand, but on the other how they could also be highly exclusive, setting up alternative criteria that elevated the worshiping group, galvanizing them in this case through the authority of the past.

Although Mylasa was an ancient regional center, it only took shape as an urban center under the Hekatomnids in the fourth century. Mylasa was the hometown of Hekatomnos, who was appointed satrap during the reign of Artaxerxes II (404-358 BC) and was surely already a prominent figure among the Karian elite. ${ }^{10}$ Karia underwent a major transformation at the hands of the Hekatomnid dynasty, particularly Maussollos (c. 377/6-353/2 BC), successor

See also Williamson (2013e). I am grateful to Frank Rumscheid, who commented on an earlier draft and corrected several of my interpretations on the urban area of Mylasa, particularly with regard to the sanctuary of Zeus Osogollis. Any remaining errors here are entirely my own.

8 Some finds from the Mycenaean period were found in the area, but most begin in the eighth to seventh century вC, Rumscheid (1999b); 206, also (1999a), 171-176 on Late Geometric pottery found in the fill of a Roman peristyle building in Milas. Rumscheid (1999b), 206-207 further argues against the Mylasa originally being located on the fortified hilltop at Beçin Kale, five kilometers to the south (e.g. Cook 1961), as unsubstantiated. Hdt. 1.171.23-30 (transl. A.D. Godley (1922) The Persian wars, LCL 119). The Karian League was especially active in the fifth and fourth centuries during the Ionian revolt, Hdt. 5.37.1-3, 5.119.7-10, and 5.121.2-8. Their role seems to have subsided somewhat with the rise in the third century of the Chrysaoric League (see below on Labraunda).

10 On the Hekatomnids in general: Hornblower (1982); Ruzicka (1992); Pedersen (20012002); Carstens (2009). 
to Hekatomnos, who embarked upon a building program across the region that resulted in several defense systems, monumental sanctuaries, the consolidation of cities (synoikisms), and the rise of Halikarnassos as cosmopolitan center. The Hekatomnids gave Karia, traditionally made up of clusters of hilltop communities, a sense of unity and consolidation that it had not known before nor would again.

Mylasa and its landscape were also central to their program. When Maussollos came to power he transferred the royal seat from Mylasa to Halikarnassos. Located on the Myndos peninsula, this was closer to the powerful international centers that he was interested in, such as Kos, Knidos, and Rhodes. ${ }^{11}$ Nonetheless, Mylasa remained a major polis in the Karian interior, where Maussollos's brother Idrieus remained as governor, until Maussollos's death in 353/2 BC, when he then assumed the role of satrap until his own death in 344/3 BC. ${ }^{12}$ Like Halikarnassos, the population of Mylasa was probably inflated through a synoikism of the existing settlement with some of the surrounding hilltop communities, e.g. at Beçin Kale and Gençik Tepe. ${ }^{13}$ Mylasa's divisions of phylai and syngeneiai (kinship groups) appear to incorporate the living memory of many of these local communities.

Mylasa lies in a fertile plain and its exposed position, rather than on a defensible hilltop, was noted by Strabo as unusual for such a prominent city. ${ }^{14}$ Maussollos is reported to have taxed the citizens for a circuit wall, although there is no evidence that this was actually built. ${ }^{15}$ Frank Rumscheid, however, observed that a considerable system of fortifications dating from the Hekatomnid period may be located on the hills around the city, while Reger and Descat have shown that the main routes of access to the plain were highly

11 Poul Pedersen (2013) gives an enlightened discussion of the 'Ionian renaissance' as an indication of the 'Hellenization' of Karia in opposition to Hornblower's view of the 'Karianization' of Karia, Hornblower (1982).

12 In the early Hellenistic period, the Macedonian satrap Asandros may even have moved the residency back from Halikarnassos to Mylasa where he received ambassadors, see Hornblower (1982), 103 and n. 192. Strootman and Williamson (2020) on the juxtaposition of monumental building in Halikarnassos and Mylasa, especially Labraunda.

13 Rumscheid (2010), 96-99. This corresponds with the description in Strabo 12.2.23 of Mylasa as a village $(\kappa \omega \dot{\omega} \mu)$ in ancient times. The name 'Mylasa' is plural, perhaps reflecting a collective of communities (my thanks to Pontus Hellström, who pointed this out to me).

14 Strabo 14.2.23, 'But one may well be amazed at those who so absurdly founded the city at the foot of a steep and commanding crag. Accordingly, one of the commanders, amazed at the fact, is said to have said, "If the man who founded this city, was not afraid, was he not even ashamed?"' (transl. H.L. Jones (1929) The geography of Strabo, LCL 223). 
secured for Mylasa. ${ }^{16}$ The extent of construction activity in the town itself from this early period is largely obscured by the modern infrastructure. A glimpse came to light, however, in 2010: the monumental platform on Hisarbaşı hill, long considered the stylobate of the temple of Zeus Karios, was postulated by Frank Rumscheid as a proto-Maussolleion, based on similarity of architectural details with the Maussolleion in Halikarnassos. ${ }^{17}$ Clandestine excavations confirmed this, revealing spectacular subterranean chambers with some of the earliest vault architecture, painted walls, and a sculpted sarcophagus from the fourth century that surely belonged to one of the rulers. ${ }^{18}$ Like the Maussolleion in Halikarnassos, this major funerary monument was located at the heart of the new urban center.

As counterpoint, the shrine of Zeus Labraundos, up in the mountains north of Mylasa, was promoted by the satraps as the sacred focus of Karia, and especially of their dynasty (Figure 3.2). In the hills overlooking the plain of Mylasa they established a complex rivaled in magnificence only by Halikarnassos. Poul Pedersen draws a compelling comparison between Labraunda and the palace-temple complex on the Zephyrion peninsula in Halikarnassos. ${ }^{19}$ In both cases divine authority is combined with political power in a striking, highly prominent location. Labraunda was the most splendid sanctuary of the Hekatomnids, but not the only one to enjoy their patronage. The sanctuary of Sinuri also benefitted from their building program, proving its relevance at this time. While the inscriptions at Labraunda are in Greek, communicating to a cosmopolitan audience, the bilingual inscriptions at the shrine of Sinuri

16 Rumscheid (1999b); Reger (2010) on the question of the 'Little Sea' towards Iasos, and Descat (2013) on the route from the south near Hydissos and Sekköy/Talagreia.

17 Rumscheid (2010). This structure on Hisarbaşı hill, locally known as Uzunyuva, consists of a large platform with a single Corinthian column (with a stork's nest, hence the name Uzunyuva, 'tall nest'). This was long held to be the temple of Zeus Karios based on Herodotos's description of this shrine as being in Mylasa: also Hdt. 5.119.2, e.g. Laumonier (1958), 43; Bean (1971 [1989]), 22. Further researched by Voigtländer (1991). The single Corinthian column is an honorific monument from the mid-first century вС for the orator Euthydemos, Rumscheid (2010).

18 In the fall of 2010, illegal excavations exposed the burial at a depth of $12 \mathrm{~m}$ below the platform (see e.g. dailysabah.com/travel/2018/o8/o1/monumental-tomb-in-turkey-opensnew-horizons-in-history-of-archaeology). At a conference in Münster in 2013, Abuzer Kızıl described the architecture, while Fahri Işik proposed that the intended occupant was Hekatomnos: Kızll (2013); Işsk (2013). Rumscheid's analysis suggests a later date, more consistent with Idrieus. On Hekatomnid tombs, see also Henry (2010) and (2014), and Pedersen (2017).

19 Pedersen (2013), 41, also (2009), 334-337. Apollo was the principal deity in Halikarnassos and Pedersen includes the Hekatomnid coinage showing a Hellenic Apollo on the obverse and Karian Zeus Labraundos on the reverse; see also Konuk (2013). 


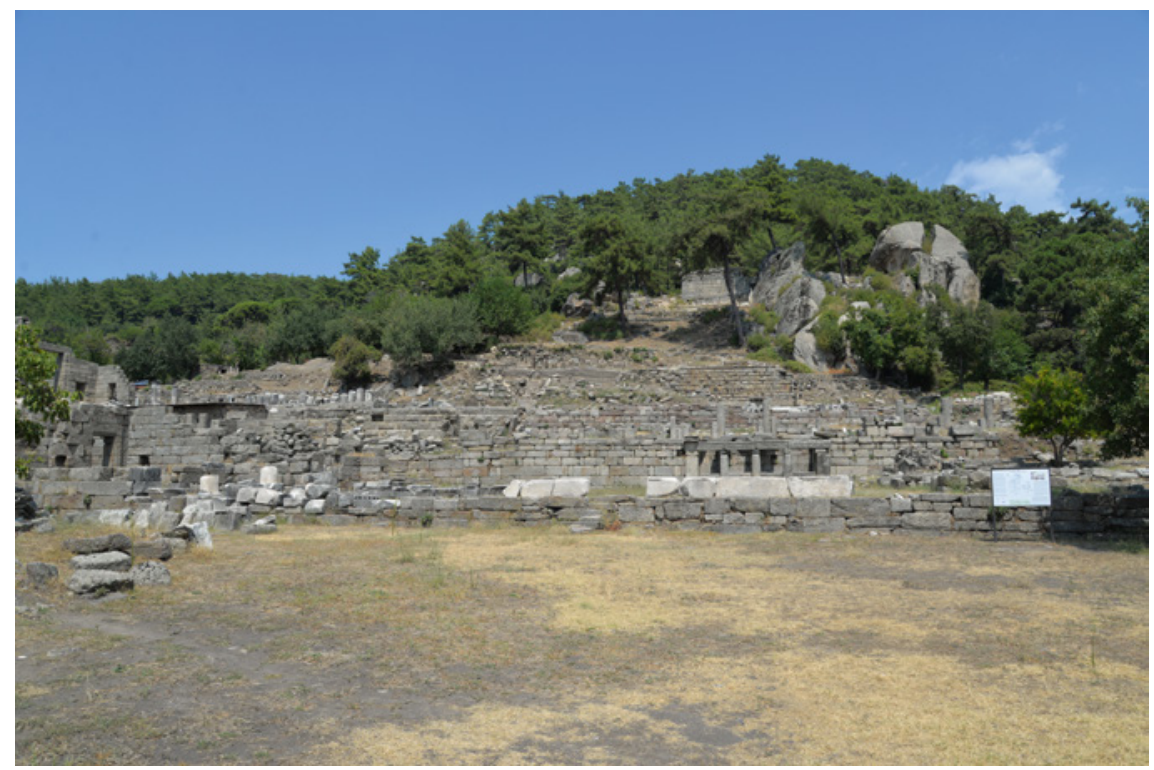

FIGURE 3.2 Labraunda. View of the sanctuary, with the split rock in the upper right PHOTO AUTHOR 2019

underscore the deeply Karian nature of the god and his community, a syngeneia, a kind of kinship collective. This syngeneia appears to have been independent until the Hellenistic period, when control over the shrine shifted to a syngeneia under a different name that clearly belonged to Mylasa. ${ }^{20}$ Sinuri was not an urban deity, yet the incorporation of his shrine into the area annexed by Mylasa demonstrates the territorial extent of the polis by this time. More importantly, the way it was administered illustrates how sub-communities could use sanctuaries just as poleis did to navigate their own geographies of identity, further discussed in Chapter 4.

As mentioned above, the sanctuaries of Zeus Labraundos and Sinuri were not the only sacred sites in the landscape of Mylasa, yet they were both clearly vital to the interests and aspirations of the polis, each in a unique way. Both sanctuaries had already been targeted by the Hekatomnids in the fourth century, and both were subsequently caught up in the political, social, and territorial composition of the democratic polis after the passing of the Hekatomnids. Hellenistic Karia underwent a turbulent period as power changed hands several times between the Macedonians, Ptolemies, Seleukids, even Rhodes,

20 The bilingual inscriptions are I.Sinuri $73^{-75}$, see Adiego (2000). The sanctuary at Sinuri was specific first to the Pelekos syngeneia and later that of Pormounos; see below. 
and finally Rome. ${ }^{21}$ An early indication of the effect this had in the area is the stronghold at Kuyruklu Kalesi. ${ }^{22}$ The fortified plateau may have served as a place of refuge for the Mylasans, whose vulnerable polis was in the valley and still unprotected by walls. In the early third century BC, the Ptolemies were active in this area along with the Chrysaoric League, a Karian federation that was sympathetic towards the Ptolemies and later settled near Stratonikeia. ${ }^{23}$ Antiochos II reacted and seized Mylasa from Ptolemaic influence, and in the 24OS BC his successor Seleukos II 'liberated' the polis through his strategos (general) Olympichos, who then took up residence in the area as governor. ${ }^{24}$ During his regency, controversies arose between the priests of Labraunda and Mylasa, and although they escalated to the king, Olympichos played a key role in settling them in favor of the polis. Some twenty years later, however, he was directed to evacuate the region under the rule of the Macedonian Philip v, who firmly declared that Labraunda belonged to Mylasa. ${ }^{25}$

Towards the end of the third century, Mylasa entered into a peaceful agreement of civic equality (isopoliteia) with Miletos, inscribed at the sanctuaries of Zeus Labraundos, Zeus Osogollis (in Mylasa), and Apollo Didymeus near Miletos. ${ }^{26}$ The third century, however, ended in geopolitical turmoil when Antiochos III, and especially his general Zeuxis, swept through the area of Mylasa in their campaign to restore the old extent Seleukid kingdom. The upheaval has been interpreted by some to be at the root of the many petitions

21 Ada, sister and wife of Idrieus, was allied with Alexander the Great against her brother Pixodaros and left Karia to Alexander when she died. The following period is complex and only the key events are mentioned here; see also Billows (1995), 90-107; Aubriet (2009) and (2013).

Wolfgang Radt believes the fortifications date from the early Hellenistic period, although the site shows a settlement phase from the Archaic or Classical period, Radt (1969/70), 169-170; Rumscheid (1999b), 216-217, dates the walls to the second half of the fourth century BC by analogy with Latmos.

23 The Chrysaoric League and their Ptolemaic affiliations are evident in I.Labraunda 43-44, dated to 267 вC; see Mastrocinque (1979), 66-70 and 220-226; Gabrielsen (2000), 156-161, also (2011); van Bremen (2017). Later attempts by this league to take control of the sanctuary with Labraunda's priest are discussed below, under Legal Administration.

24 On Ptolemaic and Seleukid influence in Karia and Mylasa and the Second Syrian War, see Ma (1999), 41-42. Seleukos II's liberation of Mylasa is primarily testified in I.Labraunda 3, discussed in more detail below. Also Crampa's comments in I.Labraunda, p. 82-85; Bencivenni (2003), 247-298, esp. 265ff., and Aubriet (2012). A brief discussion of the date is given in Carless Unwin and Henry (2016), 31, n. 15. Olympichos's position in the area is discussed further below, but see also: Debord (1969); Isager and Karlsson (2008); Debord (2011); Isager (2011); Aubriet (2012); Henry and Aubriet (2015); van Bremen (2016); Carless Unwin and Henry (2016); Marek and Zingg (2018), 120-126.

25 As is evident from I.Labraunda 5 , discussed below.

26 Milet I,3 146; Staatsverträge III 273-276, no. 539. 
for asylia by towns for their sanctuaries and territories in this era. ${ }^{27}$ Their troops took the town and apparently pillaged the countryside, including some of the lands belonging to Sinuri. These were later restored through Antiochos's intervention, who took further measures to ensure that the shrine of Zeus Labraundos would be left in peace. ${ }^{28}$ This was a defining moment for the Hellenistic polis, which leveraged the great sanctuary at Labraunda to negotiate its position with the ruling powers. ${ }^{29}$

The second century began more peacefully. Mylasa was one of the cities declared independent after the Treaty of Apamea in 188 BC, but was nonetheless attacked by Rhodes after the island power was bereft from its peraia on the mainland in Karia by Rome in $167 / 6$ BC. The attack was, however, prompted by Mylasa's occupation of neighboring Euromos in the wake of the power vacuum left by Rhodes. ${ }^{30}$ This only slowed Mylasa's expansion. Eventually it engaged in sympoliteia with Olymos and Euromos and absorbed the surrounding communities of Labraunda, Chalketor, and Hydai. ${ }^{31}$ At some point it established a harbor facility at Passala. ${ }^{32}$

The Mithridatic Wars in the 8os of the first century had little impact on Mylasa. The city's eastern neighbor, Stratonikeia, would come out of this event with solid ties to Rome that significantly propelled it forward. By the middle of the century, Mylasa had become one of the provincial courts of Asia Minor (conventus Asiae). Yet in the $4 \mathrm{OS}$ BC, Mylasa suffered heavily from the attacks

27 Mastrocinque (1984); Flashar (1999); Knäpper (2018). On this period in the history of Mylasa, see esp. Ma (1999), 67-70; also W. Ruge in $R E$, s.v. 'Mylasa', esp. 1050-1052.

28 On the occupation of lands belonging to Sinuri, Virgilio (2010), and below. Antiochos III's letter promising to respect Labraunda is I.Labraunda 46 . The turbulence created by the campaigns and conquests of Antiochos III is sometimes seen as a motive for the surge of asylia inscriptions at sanctuaries, discussed in Roels (2018a), esp. 234-238, with references.

29 E.g. Debord (2011), Reger (2010); further discussed below.

$30 \quad$ Polyb. 21.46.4 and Livy 38.39.8 on Mylasa and Rhodes after the Treaty of Apamea in 188 BC. On the political situation between Rhodes, Mylasa, and Euromos after 167 BC, Polyb. 30.5.11-15; Livy 45.25.11-13; see also Rigsby (1996), 407-415, nos. 187-209.

31 On Mylasa's expansionist policy, see Reger (2004), 164-168 and Reger (2010), identifying two pulses in Mylasan expansion: a mid-fourth century, under Maussollos, and one that the polis initiated in the mid-third century via sympoliteia of neighboring poleis. I.Labraunda 137 offers further evidence of a sympoliteia with neighboring Olymos at this time, Henry and Aubriet (2015), 699; this inscription designates the area between Mylasa, Olymos, and Labraunda under the topnym Larysynia, Carless Unwin and Henry (2016). Epigraphic evidence for property holdings in this area is examined in van Bremen (2016), $11-16$.

32 The importance to landlocked Mylasa of Passala and 'the little sea' are discussed in Reger (2010), and now Aubriet (2017). The acquisition of coastal property by Mylasa from Kindye is discussed in detail in Descat (2013), van Bremen (2013), and again Descat (2014). 
by Labienus and his Parthian troops. Strabo blames this in part on the taunting of the orator Hybreas, who, however, also helped restore the city afterwards. ${ }^{33}$

Political bodies known from inscriptions reflect the transition to the Hellenistic era in Mylasa. Under the Hekatomnids, decisions at Mylasa were made in the kyria ekklesia, the regular assembly meeting as prescribed by law, and were ratified by 'the three tribes.' ${ }^{34}$ These tribes may well have been remnants from the Hekatomind synoikism of the surrounding communities. The tribes are thought to continue in the Hellenistic period, when the population of the city was reorganized into three main phylai: the Otorkondeis, the Konodorkondeis, and the Hyarbesytai, with the Otorkondeis making the most frequent appearance in the inscriptions. ${ }^{35}$ Another level of sub-community was the syngeneia, or 'kinship' group, as mentioned above in connection with the sanctuary of Sinuri. Some of these were subsidiary to a phyle; e.g. the Tarkondareus syngeneia and that of the Maunnites both belonged to the Otorkondeis phyle, while the Aganiteis syngeneia belonged to the phyle of the Hyarbesytai. ${ }^{36}$ Other syngeneiai certainly operated within the sphere of the polis, such as the syngeneia of Korris at Labraunda, and of Pormounos at the sanctuary of Sinuri. It would seem that participation within syngeneiai was not mutually exclusive. Members of the Tarkondareus syngeneia were also active within the Pormounos syngeneia; one of the later priests at Labraunda belonged to the Maunnites syngeneia but would also have been involved with

33 Quintus Labienus was a commander under Brutus who had just mustered Parthian support when he learned of Brutus' downfall; instead of bringing them to Rome as planned, he began a rampage through Asia Minor, hoping to take the province by force. This episode is discussed in more detail below, in relation to Stratonikeia, as it had more impact on the sanctuaries of Hekate at Lagina and Zeus at Panamara. Strabo 14.2.24 tells of the role of Hybreas in the devastation of Mylasa by provoking Labienus, but also in its restoration.

34 E.g. I.Mylasa 1, 2 are decrees in the mid-fourth century using the clause: हैंठ

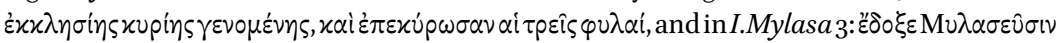

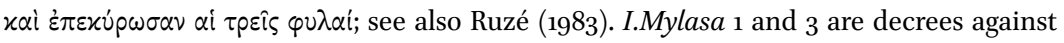
persons who plotted against Maussollos in $367 / 6$ and $355 / 4$ (an assassination attempt during the festivals at Labraunda); I.Mylasa 2 is a decree against the sons of Peldemos for damaging a statue of Hekatomnos in 36o/1; see Caldesi Valeri (1998); Hornblower (1982), 68-70.

35 See also Rhodes and Lewis (1997), 341-347 on the development of the Mylasan political system; they also observe how the phylai also passed honorific decrees for those who performed positive actions towards the polis, p. 344-346 n. 2 referring to Jones (1987), 328-332.

36 On the Tarkondareus and Maunnites, W. Ruge in $R E$, s.v. 'Mylasa', 1055-1056; on the Aganiteis, I.Mylasa 121-122; see also below in the discussions of the sanctuary of Sinuri (Chapter 4). 
the Korris syngeneia at Labraunda, presuming that this was still active in the late second century вс. ${ }^{37}$ Most of these sub-communities had their own cults to Zeus. ${ }^{38}$ This plethora of groupings, and each with its religious center of gravity, explains in part the rich sacred landscape of Mylasa and Laumonier's observation on the disproportionate number of cults for the population. ${ }^{39}$

In this sense, it is important to realize that different sanctuaries served different and overlapping layers of Mylasan identities, whether syngeneia, phyle, or the civic body as a whole. The Otorkondeis, for example, held in common the sanctuary of Zeus Otorkondeon, but they also played a prominent role in the administration of the sanctuary of Zeus Osogollis, which became one of the primary urban sanctuaries of Mylasa. Labraunda, on the other hand, was much more of a regional sanctuary, interwoven with Karian (and Hekatomnid) identity, but now also carried the political identity of the city in its slipstream. At the same time it was the platform for the local syngeneia of Korris. The sanctuary of Sinuri was the focal point for the identity of the Pormounos syngeneia. Mylasan society was thus highly nested, with the many overlapping segments having a religious center through which they could celebrate themselves and negotiate their layered identities.

Examining the sanctuaries in the more remote regions of the chora of Mylasa as urban spaces will enable a better understanding not only of how they functioned, but also of the different ways in which they were significant to the polis, what kind of urban identity was expressed through them, and the role that their location in the landscape may have had in determining their significance.

The case study of Labraunda demonstrates several dynamics that could be involved as a polis acquired control over a major sanctuary of regional

37 E.g. Pammenes, son of Hermogenos, of the Tarkondareus was one of the ktematonai, or sacred land managers, for the Pormounos syngeneia, I.Sinuri 47a and 50. Hekatomnos, son of Ouliades, and priest of Labraunda in the late second century BC was also active in the Maunnites syngeneia, e.g. I.Mylasa 501; see below on the Korris syngeneia.

$38 \quad$ E.g. the phylai of the Otorkondeis and Zeus Otorkondeon and the Hyarbesytai with Zeus Hyarbesyton; the syngeneiai of the Aganiteis at their sanctuary of Zeus Aganiteon and of the Maunniteis with Zeus Maunniton; discussed further towards the end of this chapter. Laumonier (1958), 39. The sanctuaries of the phylai and syngeneiai are discussed in more detail at the end of Chapter 4 , as it is relevant to the community at the sanctuary of Sinuri.

40 This section draws from Williamson (2013d), (2013e), (2014a), and (2014c). I am particularly indebted to Pontus Hellström, Lars Karlsson, Olivier Henry, Axel Frejman, Jesper 
significance. This case study explores the impact of the legacy of the Hekatomnids at Labraunda and the bearing that this continued to have on the relationship between the sanctuary and Hellenistic Mylasa.

As the Hekatomnids moved their satrapal seat to the coast at Halikarnassos, they simultaneously designated the mountain shrine of Zeus Labraundos, near their hometown of Mylasa, as their primary sacred center (Figure 3.2). The splendor of the complex resonates with royalty, as does the monumental approach via the paved road that connected the shrine with Mylasa and reinforced it as the primary point of contact for this central Karian cult. The selection of the sanctuary of Zeus Labraundos, rather than the renowned Zeus Karios, is significant and underscores a conscious decision to tie this sanctuary in particular to the Hekatomnid dynasty. Part of this is surely connected with the landscape and position of the shrine on a mountainside overlooking the plain of Mylasa and beyond to much of their territory. The monumentality given to Labraunda by the Hekatomnids is discussed in detail in this section, in particular as it relates to the landscape. It is this combination that lent the shrine a power of place that explains a great deal of why Hellenistic Mylasa also selected this sanctuary, out of all those in its territory, to represent itself in the turbulent years that followed the passing of the Hekatomnids. This is when the polis struggled to redefine its political position amidst changing kingdoms and maintain its grip on the mountain shrine. Labraunda itself became contested space and the changes that took place in the Hellenistic period were primarily about control, rather than adding to the complex or its rituals in any major way. In fact, the noticeable lack of change at the site has been interpreted by the excavator Pontus Hellström as a deliberate attempt at retaining the Hekatomnid legacy, and turning this powerful sanctuary into a 'memory theater.41

\subsection{Historical Overview of Labraunda}

Finds at the site go back to the seventh century BC, although the earliest literary reference to Labraunda is in Herodotos, in connection with the Ionian revolt in 497 BC, when the Persians defeated the Milesians and their Karian allies in a battle near the Marsyas (Çine) river:

Presently, when the Persians had come and had crossed the Maeander, they and the Karians joined battle by the river Marsyas. The Karians

Blid, and Felipe Rojas for many discussions of the excavations, and for sharing their thoughts on the biography and nature of Labraunda. 
fought obstinately and for a long time, but at the last they were overcome by the odds. Of the Persians, as many as two thousand men fell, and of the Karians ten thousand.

Those of them who escaped were driven into the precinct of Zeus of Armies [Zeus Stratios] at Labraunda, a large and a holy grove of planetrees. (The Karians are the only people whom we know who offer sacrifices to Zeus by this name.) When they had been driven there, they deliberated how best to save themselves, whether it would be better for them to surrender to the Persians or to depart from Asia. ${ }^{42}$

Herodotos thus describes the sanctuary of Zeus at Labraunda in the Archaic period as a modest shrine with a sacred grove of plane trees, indicating an open-air shrine. Archaeological evidence, however, indicates that there was a temple and a mud-brick altar, discussed below. Herodotos's depiction of the Karians discussing their odds at the sanctuary is sometimes taken as proof that the sanctuary was the meeting place of the Karian League, ${ }^{43}$ although the text only states that they were driven ( $\kappa \alpha \tau \varepsilon 1 \lambda \dot{\eta} \theta \eta \sigma \alpha \nu)$ there by the Persians, probably in pursuit from Alabanda in the north.

The history of the site changed when Hekatomnos targeted Labraunda as the sacred center of Karia, radically reshaping the hillside into a cascade of terraces that supported an innovative monumental complex, connected to Mylasa by a paved road. The bulk of building activity is now believed to have taken place between 377/6 and 351/о вС, i.e. while Maussollos was still satrap and Idrieus was governor of Mylasa. ${ }^{44}$ The initiative of the Hekatomnids will have served to create a triangular relationship between the rulers, the sanctuary (and its priests), and the communities in and around Mylasa, which despite the Karian scope probably made up the largest group of worshipers at the shrine. With its sumptuous architecture and majestic setting, Labraunda may well have functioned as an 'extended palace' for the Hekatomnids where they

42 Hdt. 5.119.1-2 (transl. A.D. Godley (1922) The Persian wars, LCL 119). This passage relates to the sanctuary as a place of refuge for the Karians during the Ionian revolt, where the Karians met to discuss further plans. The epithet for Stratios, 'war-like', is also used by Strabo (14.2.23), and also applies to Zeus at Amaseia (App. Mith. 66, 70), but otherwise rarely appears at either Mylasa or Labraunda and will not be further discussed in this context.

43 E.g. Kaletsch in Brill's New Pauly (2006) s.v. 'Labraunda': "The shrine was the central meeting place of the old Karian league (Hdt. 5.119.2) with its annual panēgyrís."

44 E.g. Hellström (2011a), 355. "I suggest that both andrones were erected during the lifetime of Maussollos, that Andron B was built in the 370 s and that Andron A was dedicated not later than 351/o, before Artemisia died and Idrieus became satrap." 
received their audiences in a staged setting, as Anne Marie Carstens argues. ${ }^{45}$ This viewpoint is gaining ground. Olivier Henry, the current excavator, interprets much of the complex as palatial while the sacred precinct was restricted to the temple terrace. ${ }^{46}$ The palace-temple combination would in this case mirror the situation on the Zephyrion peninsula in Halikarnassos, where the royal palace was constructed in close range to the temple of Apollo. After his move to Halikarnassos, Maussollos in fact began to issue coinage with Apollo on the obverse and Zeus Labraundos on the reverse. This not only linked the cosmopolitan deity with mountainous Karian god, but by association established a connection between the coastal residence and the sacred center deep in the heart of Karia, as Koray Konuk and Poul Pedersen have noted. ${ }^{47}$ Labraunda appears to have been intended as a counterpart to Halikarnassos in several respects, including a dynastic burial, if the Built Tomb above the temenos indeed contained the remains of early family members, as has been suggested. ${ }^{48}$

After the passing of the Hekatomnids, the shrine underwent little change. Two monumental fountains appear to have been added, but otherwise the complex remained largely as designed by the Hekatomnids. During the third century, around 240 BC, the sanctuary and its property came to be contested space as the priest of Labraunda made a direct appeal to Seleukos II against Mylasa's financial involvement. Seleukos ordered the affair to be investigated by Olympichos, his governor in the area, who decided in favor of Mylasa. Some twenty years later, a second and more serious attempt to take control of the sanctuary was made by the priest at that time, together with the Chrysaoric League, which may have convened at the sanctuary. ${ }^{49}$ Philip v, who was then ruler, declared in the end that Labraunda belonged to Mylasa, and the matter

45 "I believe that Labraunda was the key sanctuary for the Hekatomnids, where they staged and used the rural site as an extended palace, suited for processions, audiences, banquets in a magnificent setting ... under the protection of an ancient deity," Carstens (2009), 100; also Karlsson (2015a) on Labraunda as a Persian paradeisos.

46 Henry (2017).

47 Konuk (2013), 107-108; Pedersen (2013).

48 Henry (2017), 566-568. The suggested combination of palatial residence, religious center, and royal burial in an extra-urban setting is reminiscent of El Escorial near Madrid, that was at once monastery, royal burial place for Charles V, and palace for Philip II, a combination discussed further in Strootman and Williamson (2020).

49 On the Chrysaoric League, see now Gabrielsen (2011). The League was already involved with Labraunda in the early third century, I.Labraunda 43 and 44; their attempt with the priest to take control of Labraunda towards the end of this century is recorded in I.Labraunda 5 . 
was apparently settled. ${ }^{50}$ Towards the end of the third century, the sanctuary was protected from attack by Seleukid troops thanks to a letter posted at the entrance from Antiochos III, ordering his commander Zeuxis to ensure that the sanctuary was protected. ${ }^{51}$ Labraunda was thus more fortunate than the shrine Artemis at Amyzon, and of Sinuri.

Despite the decrease in building activity in the Hellenistic period, finds and inscriptions show that Labraunda continued to function as a major sanctuary, albeit for Mylasa, reinforcing the picture given to us by Strabo. The ongoing popularity of Labraunda in later times is indicated by a second phase of building activity in the imperial period. Several inscriptions concerning dedications and regulations date indicate the popularity of the shrine in the first and second centuries AD; in this period Labraunda became famous for its pool of oracle fish with golden earrings. ${ }^{52}$ In the fourth century the sanctuary was changed once more into a large Christian complex, with at least two churches and a tetraconch bath. ${ }^{53}$

In short, we can distinguish five general phases in the life of the sanctuary at Labraunda, beginning with: 1) the Archaic period, when the cult place of Zeus Labraundos was a modest shrine; then 2) the Late Classical period, when it was radically transformed into a monumental and palatial complex by the Hekatomnids; 3) the Hellenistic period when the polis of Mylasa rose to the foreground; 4) the imperial period, when the festivals were re-organized by the polis and additional buildings were added; and finally 5) Late Antiquity, when the sanctuary was turned into a major Christian center. This study focuses on the transformation of Labraunda in the Late Classical and Hellenistic periods.

\subsection{Data and Sources}

Until its discovery in the nineteenth century, Labraunda was only known through the references in Herodotos (5.119) and Strabo (14.2.23) mentioned above. After some expeditions in the mountains north of Mylasa, it was identified in 1827 by Anton Prokesch von Osten, and confirmed in 1838 by Count

$5^{\circ}$ I.Labraunda 5 , discussed in detail below in the section on the Legal Administration of Labraunda.

$5^{1} \quad$ I.Labraunda 46.

$5^{2} \quad$ Plin. $H N$ 32.16; Ael. $N A$ 12.3o.

53 On the structures from Late Antiquity, see Jesper Blid in Karlsson (2010), 80-9o, and Blid (2011). The construction of a monastery in the area of Herakleia under Latmos, as well as the basilica built at the sanctuary of Sinuri speaks of a highly active Christian community in the hills around Mylasa in this later period. 
Hermann Pückler-Muskau. ${ }^{54}$ Nearly a century later the first systematic investigations of the site were undertaken by Alfred Laumonier, in anticipation of future excavations that were unfortunately impeded by the second World War. ${ }^{55}$

Excavations were eventually undertaken by the Swedish in 1948, under the direction of Axel Persson from Uppsala University, continuing until 1953, with one extra campaign in 1960 directed by Alfred Westholm of the Gothenburg Art Museum. The pottery was studied by Pontus Hellström in 1965, whose focus was primarily on the pieces that could be identified at the time, the imported ware. ${ }^{56}$ This is one of the earliest detailed publications of pottery and lamps in southwest Asia Minor, following that of Priene in $1904 .{ }^{57}$ Hellström's main objective was to present a typology for the pottery at Labraunda that could serve as comparative material for other fieldwork in the region, as at Iasos and Aphrodisias. At the time he observed a decline in the quality of the ceramics in the Hellenistic period. ${ }^{58}$ Hellenistic pottery, however, is a growing field, and Hellström expressed the hope that future studies from other contemporary sites would lead to a better understanding of ceramics in Karia, perhaps even changing the results from Labraunda. ${ }^{59}$

After the initial excavations, continuing studies of the architecture of Labraunda mandated further investigations. This took place under the auspices of the Swedish Institute in Istanbul and under the direction of Pontus Hellström in seven campaigns from 1988 to 2003. From 2004 until 2012 the fieldwork was directed by Lars Karlsson of Uppsala University. In 2012 the excavations at Labraunda became an international project and is currently under the direction of Olivier Henry, of the University Lumière Lyon, and the Institut

54 Anton Prokesch von Osten published his discovery in Denkwürdigkeiten und Erinnerungen aus der Orient 1.III, 449-450. The German count Hermann Pückler-Muskau followed the suggestions of W.M. Leake in 180o. Richard Chandler thought he had re-discovered Labraunda in the expedition of the London Society of Dilettanti in 1764-1766, but in fact he found nearby Euromos; see Hellström (2011b), which is the source of information for the rest of this paragraph. I am very grateful to Pontus Hellström for his generosity in sharing this article and his article on the andrones in advance of the publication of Labraunda and Karia.

55 Laumonier (1936), 303-318.

56 Hellström (1965). The stratigraphy of the site was widely disturbed due to postdepositional processes, and so the chronology had to be reconstructed through parallels, Hellström (1965), 1-2.

57 Wiegand (1904).

58 Hellström (1965), 13.

59 Hellström (1965), 2-3. 
Français d'Études Anatoliennes (IFEA) in Istanbul and Ömür Çakilometersaklı of Karabuk University in Ankara. ${ }^{60}$

A separate but important source of data is the coinage pertaining to Zeus Labraundos. At Labraunda itself, 418 coins were recovered during the excavations - these could potentially provide information on the wider network of the sanctuary, yet the origins of only a fraction of these have been identified so far. ${ }^{61}$ However, many specimens depicting the god, found elsewhere, have fortunately been published. The earliest appear with the Hekatomnids, whose coinage has been the subject of a number of fruitful studies leading to new interpretations of their dynastic strategies. ${ }^{62}$

The inscriptions of Labraunda have provided a wealth of data concerning the sanctuary and its relations with Mylasa, and have moreover yielded vital insights into the economy of shrines, the priesthoods and cult personnel, and royal administrative issues in this era in general. In particular, the 'Olympichos dossier' (I.Labraunda 1-12) was separately assessed by Jonas Crampa, and has proven a bountiful mine for discussions on the triangular relationship between city, sanctuary, and kingdom in the Hellenistic world. ${ }^{63}$

Labraunda is the most extensively documented out of all four sanctuaries addressed in this research. Published data sources thus include the interim excavation reports and the final volumes in the series Labraunda. Swedish Excavations and Researches, covering the architecture, inscriptions, sculpture, and pottery, as well as the preliminary reports published through the Kazı Sonuçları Toplantısı (KST) ${ }^{64}$ The 6oth anniversary of the excavations at Labraunda were celebrated in Stockholm in November 2008 and the

6o See labraunda.org/Labraunda.org/Team_eng.html for a list of team members and participating institutions.

61 Discussed in Nilsson (2011), 253.

62 E.g. Konuk (1994) and (2013); Ashton et al. (2002a); Ashton et al. (2002b). Akarca (1959) includes a thorough analysis of Zeus Labraundos and his iconography in her study of Mylasan coinage, while Delrieux (1999) examines Mylasan coin issues with both Zeus Labraundos and Zeus Osogollis, the other principal deity of Mylasa.

63 I.Labraunda Vol. III. Parts 1 and 2 (1969/1972). His translations and interpretations were critically assessed by Habicht (1972) with alternative readings suggested by Piejko (199o) and van Bremen (2017). The Olympichos dossier, discussed further below, has since been expanded with I.Labraunda 134; Isager and Karlsson (2008); Isager (2011), and I.Labraunda 137, Carless Unwin and Henry (2016) and van Bremen (2016). Several interpretations on the autonomy of sanctuaries discussed in Chapter 2 are based in part on this dossier, Debord (1982), Dignas (2002a), Boffo (1985).

64 The Kazı Sonuçları Toplantısı is the annual presentation of archaeological fieldwork in Turkey. See the Labraunda website, labraunda.org/Labraunda.org/Annual_reports_eng .html. 
proceedings provide an important supplement to the earlier publications. ${ }^{65}$ As of 2012, fieldwork reports appear in Anatolia Antiqua, journal of the IFEA. Recent fieldwork and the many exciting discoveries continuously lead to changing interpretations of the site, its function, and its history, making it quite a task to keep up with the times. The views presented here reflect the state of affairs at the time of writing, but this could easily change depending on what next year's fieldwork may bring.

\section{$3 \quad$ Environment of Labraunda}

\subsection{Physical Environment}

Located some five kilometers north of the modern village of Kargicak, Labraunda is situated at the eastern end of the Beşparmak Dağları (Figure 3.1). Both village and sanctuary are located along a ridge of the Çomakdağ that gently slopes down to the south-southwest and the plain of the Sarıçay river, just north of modern Milas. At roughly $685 \mathrm{~m}$ ASL, Labraunda is perched on the southern side of the steep hill along a passage through the mountains to the north. The shrine overlooks the point where the ridge divides in two, providing an excellent view to the plain of Mylasa as discussed below. The general area is abundant in water, some 42 springs have been documented near the sanctuary, and provides the main supply for Milas. ${ }^{66}$ Pine trees cover the area now, although the occasional plane tree is reminiscent of the sacred grove mentioned by Herodotos. 67

The Beşparmak Dağları is an ancient and heavily eroded range, known for its several worn and weirdly shaped boulders, especially farther to the west by Mount Latmos and the Bafa lake area. At Labraunda, a large egg-like boulder dominates the cult place; split from top to bottom, a niche was carved into its side (Figure 3.3) and beddings for ashlars show that a square tower was built on top, possibly as part of the temenos wall system of the fourth century or later. ${ }^{68}$ This prominent and unusual natural feature appears to have been the original locus of cult. Recent excavations revealed material dating from the late Neolithic and early Bronze Age, with a peak in the Archaic period, and

\footnotetext{
65 Karlsson and Carlsson (2011).

66 Karlsson et al. (2008), 129; Baran (2011), 52, 90-94.

67 Hdt. 5.119. The sanctuary of Sinuri was also known to have had a sacred grove, as did the sanctuary of Hekate at Lagina, Chapter 5. On sacred woods, see Cazanove and Scheid (1993), and Bonnechere (2007).

Hellström and Karlsson (2004), 76 .
} 


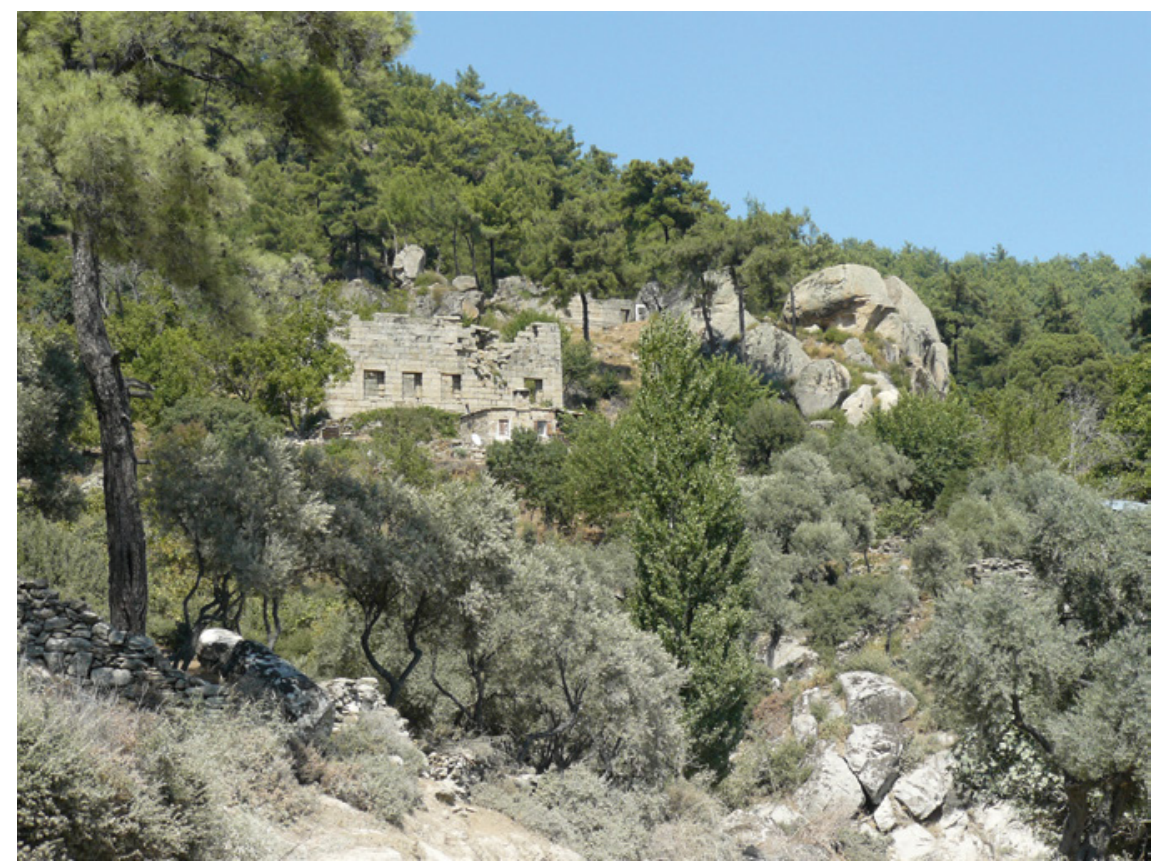

FIGURE 3.3 Labraunda. View of the sanctuary from the southwest and the sacred road. Andron A (Idrieus's andron) is to the left and the split rock to the right PHOTO AUTHOR 2010

receding in the Hellenistic era. Finds indicate that the deity worshiped here may initially have been Kybele or Meter; Lars Karlsson compellingly argues that the split boulder may represent the union of the mountain goddess with the Hittite weather god Tarhuntas, resulting in flow of springs that feed the plain below. ${ }^{69}$ Karlsson further argues that Tarhuntas, who characteristically bore a double-axe, was later identified with Zeus Labraundos, whose cult began to take precedence at the site in the Late Classical period.

69 Karlsson (2013c); Karlsson in Henry et al. (2013), 298-30o, on the excavations at the split rock in 2012. Also Karlsson (2019) and I am indebted to Lars Karlsson for sharing this paper with me, as well as his paper on the terracottas at Labraunda, including a Kybele figurine, at the conference 'Figurines de terre cuite en Méditerranée orientale grecque et romaine' in Izmir in June 2007. In this context it is interesting to note that a sanctuary for an enthroned goddess, perhaps Demeter, may have been located at Kale Mevkii, roughly 8.5 kilometers south of Labraunda along the same ridge, Rumscheid (2005). 


\section{2}

Social-Geographical Location

As mentioned above, the sanctuary of Zeus Labraundos lies along an important mountain pass to the north. ${ }^{70}$ As such it connects the green valley of the Sarıçay valley around ancient Mylasa with the fertile areas to the north near the ancient cities of Alinda and Alabanda, and the Marsyas valley, a tributary of the Maeander river. Labraunda is roughly equidistant from Alinda, 17 kilometers to the north, and Mylasa, 14 kilometers to the south, but also from the ancient towns of Euromos and Chalketor to the southwest, skirting the southern flank of the Beşparmak Dağları (Figure 3.1). The polis of Olymos was even closer to Labraunda, at roughly ten kilometers away; it is however located at the opposite end of a valley and was visually cut off from the sanctuary by the ridge running north-south. Beyond the mountains to the east lies the valley that connects with the area of Koranza and the sanctuary of Hekate at Lagina, absorbed by Stratonikeia in the second century BC, as discussed in Chapter 5 .

This ridge of the Çomakdağ carries the main road to Labraunda from the south (Figures 3.4, 3.10). Just before it approaches the sanctuary, the road, paved with smooth stone by the Hekatomnids, makes a sharp turn to the east where it continues beyond the sanctuary, then switches back to the north towards Alinda and Alabanda. Labraunda's strategic location may well have marked a vital border of Mylasa's territory to the north and in any case would have controlled the sacred road, the main passage in either direction.

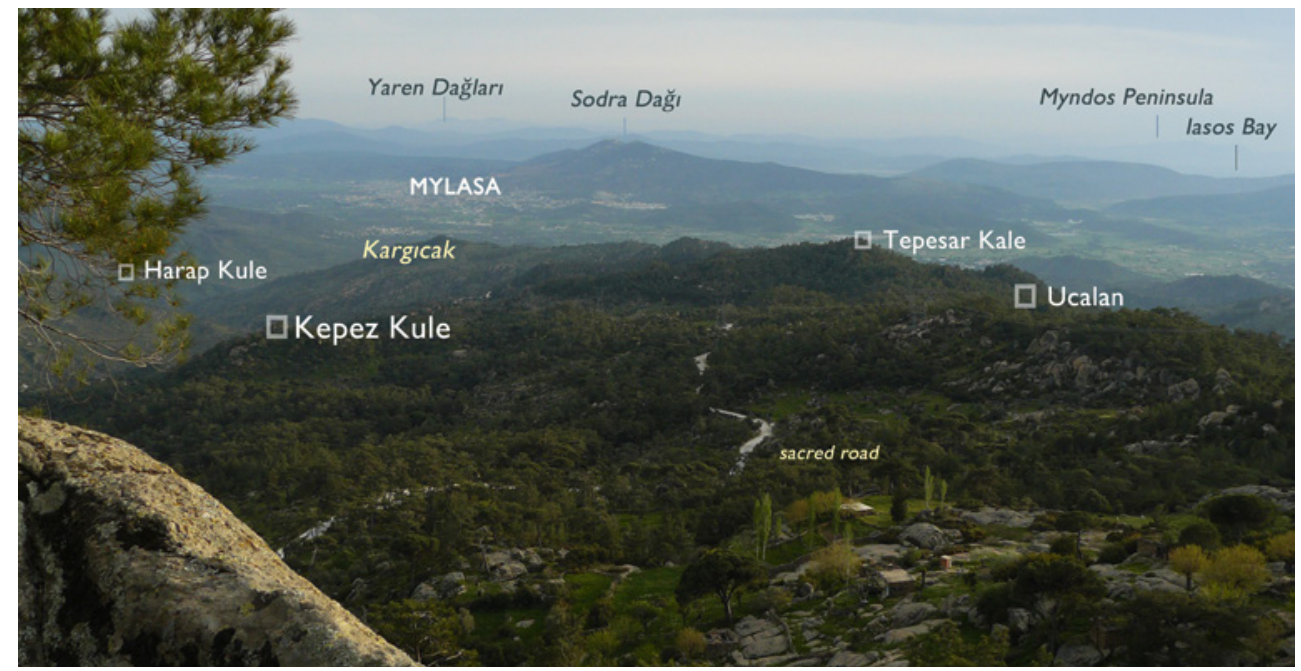

FIGURE 3.4 Labraunda. View to the south from the Akropolis Fortress. Four watchtowers (grey squares) share visibility, while Burgaz Kale is over the ridge beyond Tepesar Kale РнОтО AUTHOR 2008 
The sanctuary of Zeus Labraundos must have acted as a connecting station along this critical route that provided access to several communities in this part of Karia. ${ }^{71}$ This may explain the large number of fortifications near the sanctuary, dating from the fourth century BC. No less than five watchtowers were built at different points overlooking the route, with a modest stronghold higher up the hill, above the sanctuary (Figures 3.4, 3.5). $\cdot{ }^{72}$ Most of these shared sightlines with each other and with the Akropolis Fortress at Labraunda.

\subsection{Visibility}

Labraunda overlooks the valley just east of the Çomakdağ ridge that carries the road from the south. Perched above, the sanctuary and fortress higher up afford a breathtaking panorama across much of southwest Karia that was not lost on Lieutenant R.M. Smith, who recorded the site and its views on behalf of the British Museum in $1857 \cdot{ }^{73}$ As seen in Figure 3.5, to the west are the hills beyond Euromos and Chalketor, the sea and Iasos Bay, near ancient Iasos and Bargylia. Crowning the horizon to the southwest are the hills of the Myndos peninsula, near Halikarnassos (modern Bodrum). More to the south is the valley of the Sarcçay (the Kenios in antiquity), with modern Milas and Sodra Dağ that towers above it, the green plain to the east and south of town, including the area around Gencik Tepe and the fortified settlement of Kuyruklu Kalesi, ${ }^{74}$ the ancient plateau of Beçin Kale south of the polis, and beyond to the Yaren range separating the plain of Hydissos from the Gulf of Keramos. The southeast is dominated by the mountains of the Akdağ, east of which lie Lagina and Stratonikeia. The sanctuary of Sinuri cannot be seen from Labraunda, although the range just north of it is in full view.

This sweeping panorama must have been a determining factor by the Hekatomnids in their selection of Labraunda as primary sacred center for Karia. Encompassing much of southern Karia with Mylasa roughly at the center of this visual region (Figure 3.5), it will be argued further below that the view was equally critical to the independent Hellenistic polis as it capitalized

71 Hild (2014), 39-40. On sanctuaries as connecting stations, see Sinn (1996); Debord (1982), Ch. 1.

72 The fortifications of the Akropolis Fortress and the five watchtowers Burgaz Kale, Ucalan, Kepez, Tepesar, and Harap, discussed further below under Sacred Road.

73 Lt. Smith's report is included in Newton and Pullan (1862), 614, where after examining the windows in Andron A, he observes: "The view from them [the windows - CGW] is most striking, embracing the plain of Mylasa, Paitschin, Leros, Calymnos, Cos, Budrum, and the mountains all round." Further discussed in Laumonier (1958), 48 and Hellström (2011b).

74 On Gencik Tepe, see Säve-Söderbergh and Hellström (1997); on Kuyruklu Kalesi as a late fourth century fortification, see Radt (1969/70). 


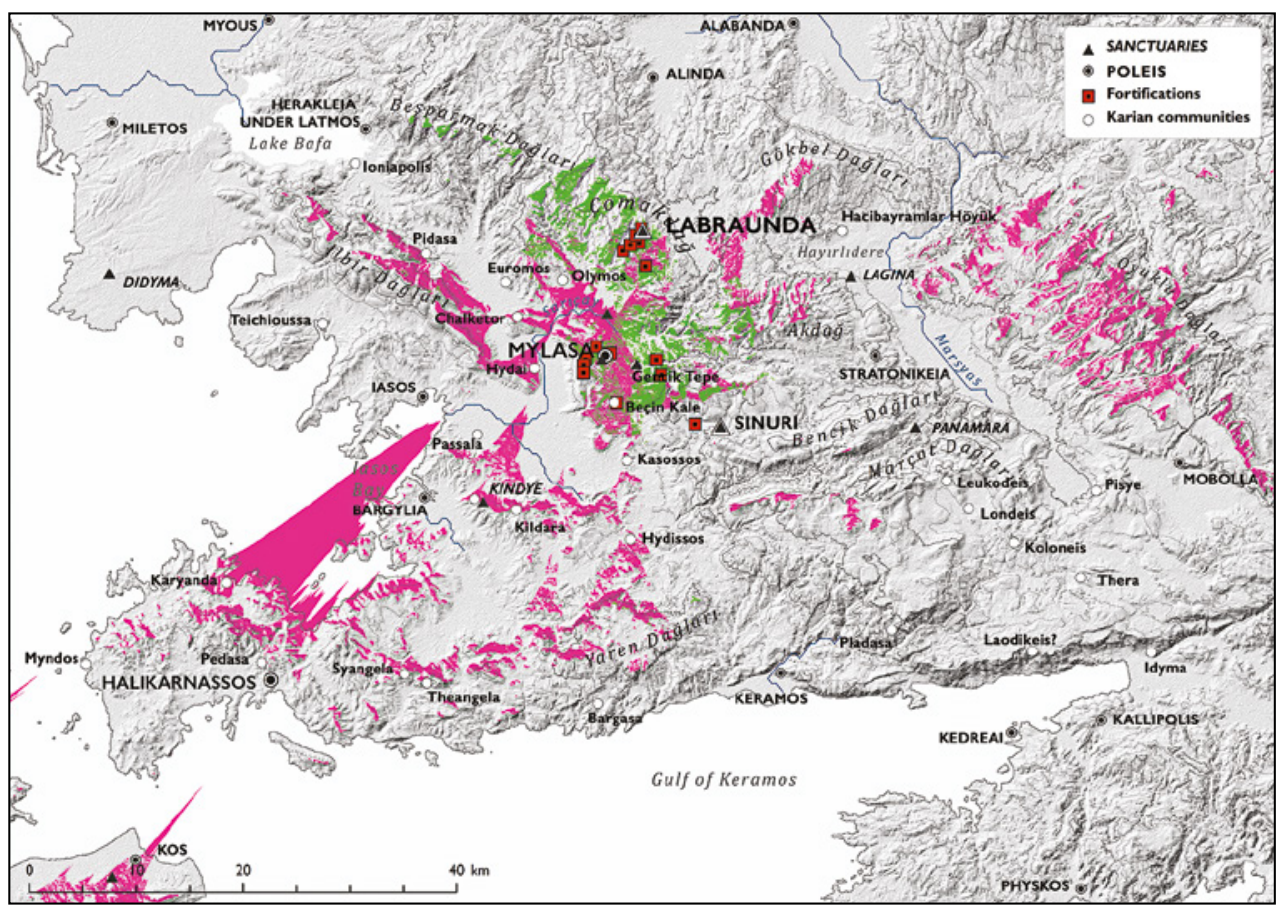

FIGURE 3.5 The viewsheds of Mylasa (green) and Labraunda (fuchsia)

on the tight integration of the sanctuary with the landscape and visual environment that the Hekatomnids had created. The landmark function of Labraunda would have been greatly enhanced by monumental architecture, making it easier to spot on the pine-clad hillside. Even today, the sanctuary may be seen from Milas as well as Beçin Kale on a clear day, if one knows where to look.

Major changes took place at the sanctuary of Zeus Labraundos under the Hekatomnids in the Late Classical period. These are closely examined here with a focus on how this impacted ritual and ritual space, but also how the later claims to the sanctuary made in the Hellenistic period. It will become apparent that, despite the annual festivals, the bond between Labraunda and Mylasa was not categorically self-evident - the polis had to go to great lengths to assert its control over the sanctuary. As contested space, Labraunda is a prime case study to observe developments in relations between city and shrine, with vested interests on the part of the polis, on the one hand, and the local priests, on the other. 


\subsection{Monumental and Ritual Space at Labraunda}

The majority of the architectural transformations at Labraunda took place in the mid-fourth century $\mathrm{BC}$, under the rule of Maussollos and his brother Idrieus. ${ }^{75}$ Prior to this, Labraunda consisted of a 'sacred grove of plane trees', mentioned by Herodotos (5.119), and a small Ionic temple in antis at the western end of a terrace, from the late sixth century вс. ${ }^{76}$ The oldest Archaic structure at the shrine, the Mudbrick Building, ${ }^{77}$ had apparently been levelled to create the terrace, which was bound to the south by a retaining wall and presumably accessed from the east via a gateway, Propylon Y. Originally constructed in the fifth century, this gateway appears to have undergone repairs in the third century $\mathrm{BC}$ and again in the second century $\mathrm{AD}$, showing its continued use. ${ }^{78}$

The Hekatomnid metamorphosis of this relatively modest shrine to Zeus into a grand ceremonial complex marks a turning point in the history of the ritual landscape of Mylasa. The dynastic aggrandizement of the sanctuary appears to have been informed as much by the Achaemenid legacy of monumental self-representation as it did with philhellenic tendencies. Labraunda was clearly a projection of ruler identity and ideology. ${ }^{79}$ Nonetheless, their use of architecture and terraces to create ensembles of coherent space that engage the wider environment was proto-typical for the Hellenistic period. Hekatomnid Labraunda clearly integrates two kinds of approaches to space: 'concentric space', i.e. space which is directed towards an internal focus, and 'linear space', i.e. space which is visually extended towards an external focus, either through a specific sightline such as a framed view, or through a physically connecting road. ${ }^{80}$ At Labraunda, both kinds create a dialogue with the landscape, while reinforcing the natural dominant position of the shrine in the region.

75 But see also Hellström (2011a), who suggests that Maussollos and Idrieus may in fact have been carrying out Hekatomnos's designs for the sanctuary, pushing the origin of these transformations further back to his reign in the first part of the fourth century вС.

76 Thieme (1993) and Hellström (2007), 40 and 111; Baran (2006) and (2009), 301-304.

77 The mudbrick structure was excavated in 1953 at the eastern end and was initially interpreted as an altar, Säflund (1956), but is now considered as possibly an early base for the cult image of Zeus, Hellström (2019). The stone foundation of the mudbrick structure is shown in Hellström and Thieme (1982), Pl.27 and as Wall 5 in Westholm (1963), 26, Fig. 15 (though somewhat normalized to the cardinal points in its orientation).

78 Westholm (1963), 106, more recently investigated in J. Blid and R. Hedlund in Henry et al. (2015), 294-304, who discuss the Roman reconfiguration of the originally Doric façade in the Corinthian order. See also Hedlund (2014).

79 See Carstens (2009), 80-100, and (2011) for Achaemenid influences at Labraunda.

80 The concepts are described at length above in Chapter 2 under Concentric and linear space. 


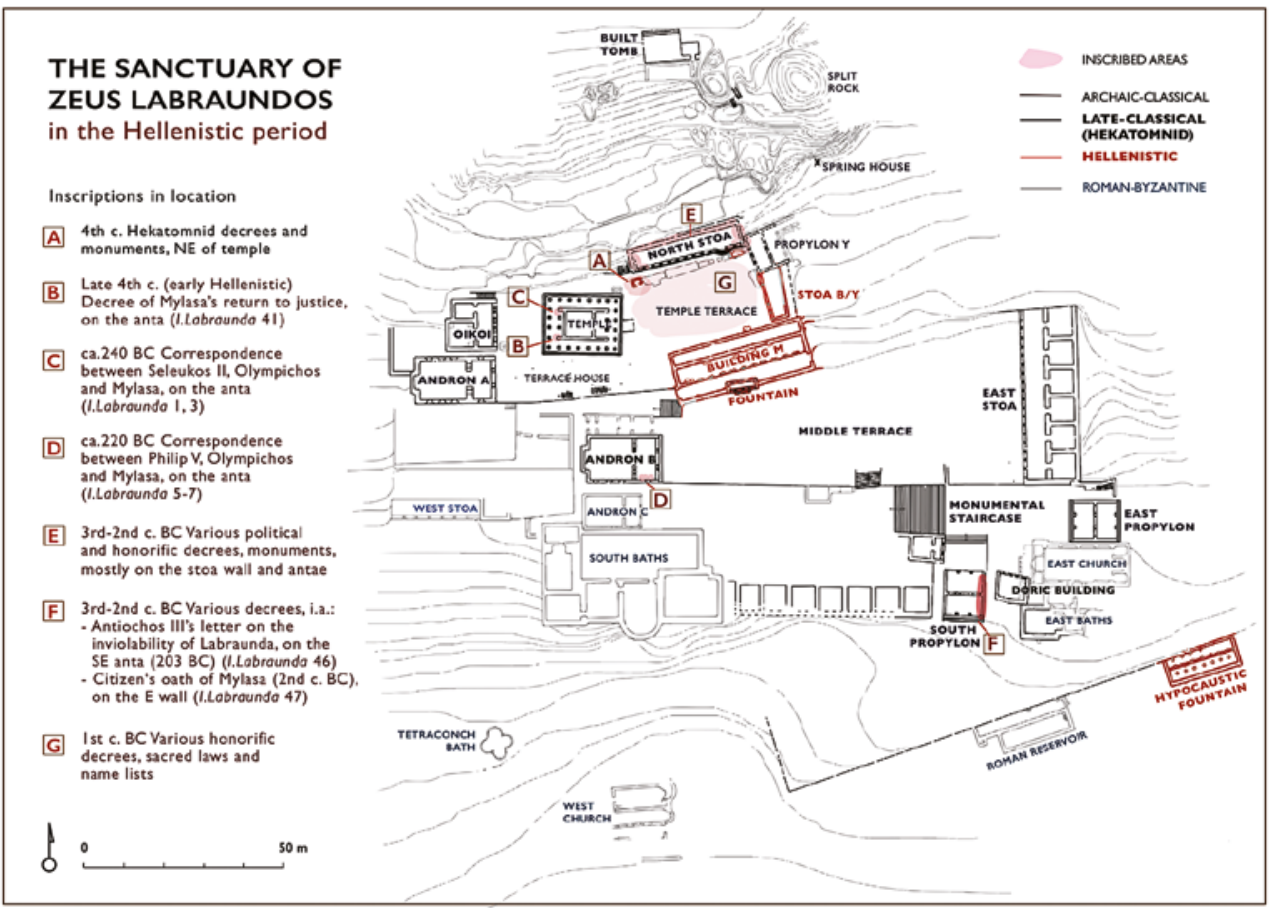

FIGURE 3.6 Plan of Labraunda in the Hellenistic period. Map after Henry (2017), Figs. 2, 15

\subsubsection{Architecture}

Several radical construction activities took place at the sanctuary in the fourth century, perhaps the most impressive of which was the massive earth excavations and retaining walls to support and display the new complex. The sanctuary, which was initially contained on the narrow temple terrace, was now extended to cover four more terraces below; the entire surface area of ritual space at Labraunda thus came to encompass $7200 \mathrm{~m}^{2} .^{81}$ Furthermore, the general orientation of the sanctuary was aligned to follow the cardinal directions rather than the natural shape of the hillside (Figure 3.6). ${ }^{82}$ The spectacle nature of the complex is underscored with the inclusion of a stadion, a rare feature for this period, and discussed below in the context of games.

81 Pedersen (1991), 99, Figure 2.99, shows the Hekatomnid expansion as $4200 \mathrm{~m}^{2}$ in addition to the $3000 \mathrm{~m}^{2}$ of the original upper terrace; Pontus Hellström however points out that the original terrace was much more modest, closer to $1000 \mathrm{~m}^{2}$ making the Hekatomnid addition closer to $6000 \mathrm{~m}^{2}$ (pers. comm. 15.04.2011).

82 Pedersen (1991), 101-102. The earlier terrace appears to have followed the natural contours of the hill, although the archaic temple is oriented towards the east. 
The complex was clearly built to impress, and terracing allowed for filtered access: the visitor was gradually guided via staircases along several stately buildings before they were allowed or invited to ascend to the main ritual space before the temple. ${ }^{83}$ This zig-zag approach may have been an intentional complication of the access to Maussollos' hall and the temple, to increase awareness of the solemn occasion and heighten the impact of the monuments. ${ }^{84}$ The sacred way led onto the first terrace, supported by an imposing retaining wall, which leveled the ground near the formal propylaia, or gateways, for those coming either from Mylasa through the South Propylon or from Alinda and Alabanda through the East Propylon. The fact that both gateways were constructed so close to each other may well be a further indication that Maussollos intended Labraunda to be a Karian-wide sanctuary, not just for Mylasa.$^{85}$ Beyond this, one traveled up the grand staircase onto the next terrace to the west (Figure 3.7), and then immediately through a smaller staircase to the north; this bottleneck must have created some congestion, heightening the anticipation of reaching the next level. Mary Hollinshead has taken on the topic of ceremonial staircases and their ritual and somatic effect, demonstrating how they create both direction and focus for the pompe. In the case of Labraunda, she argues that they were used to enhance the overall sense of spectacle, leading to the ceremonial andrones on the middle terrace. ${ }^{86}$ Pontus Hellström further argues for the use of the monumental staircase as a theatron,

83 Pedersen (1991), 114-115 on Hekatomnid terraces and the anticipation created by gradual access.

84 Hellström (1991a), 304-308 points out the trace of the route in various periods, observing similarities with Delphi; Carstens sees closer parallels with Near Eastern models of intentionally complex routes, such as at Persepolis, where "the way never directly leads towards the audience hall. There is a series of obstacles or stations on the way [...] all these hindrances serve to sacralise or solemnize the event," Carstens (2009), 86-87. With large groups of people of different ages, sexes, and mental states brought together in close quarters, processions would also have induced more mundane states of heightened awareness, and aroused emotions; also Chaniotis (2006) and (2013).

85 Hellström (2009), 270. The gateways are not strictly co-eval: the South Propylon adheres to the same schematic design as the temple of Zeus (and the temple of Athena Polias in Priene), whereas the East Propylon, which has no preserved dedicatory inscription, is less regular but more practical (lower steps, wider central doorway), and uses a different base foot-unit, Jeppesen (1955), 43-5o. Westholm believes the East Propylon was earlier, but that both were part of the same overall design, Westholm (1963), 109. Rumscheid, however, argues for later date in the third quarter of the fourth century for the East Propylon on stylistic grounds, Rumscheid (1994), 79-82 in vol. 1 and no. 119 in vol. 2. Becker believes the East Propylon was begun by Maussollos but finished at a later date, Becker (2003), 24.

86 Hollinshead (2012), 33-35 on Labraunda, and Hollinshead (2015), 11-15, also more in general. 


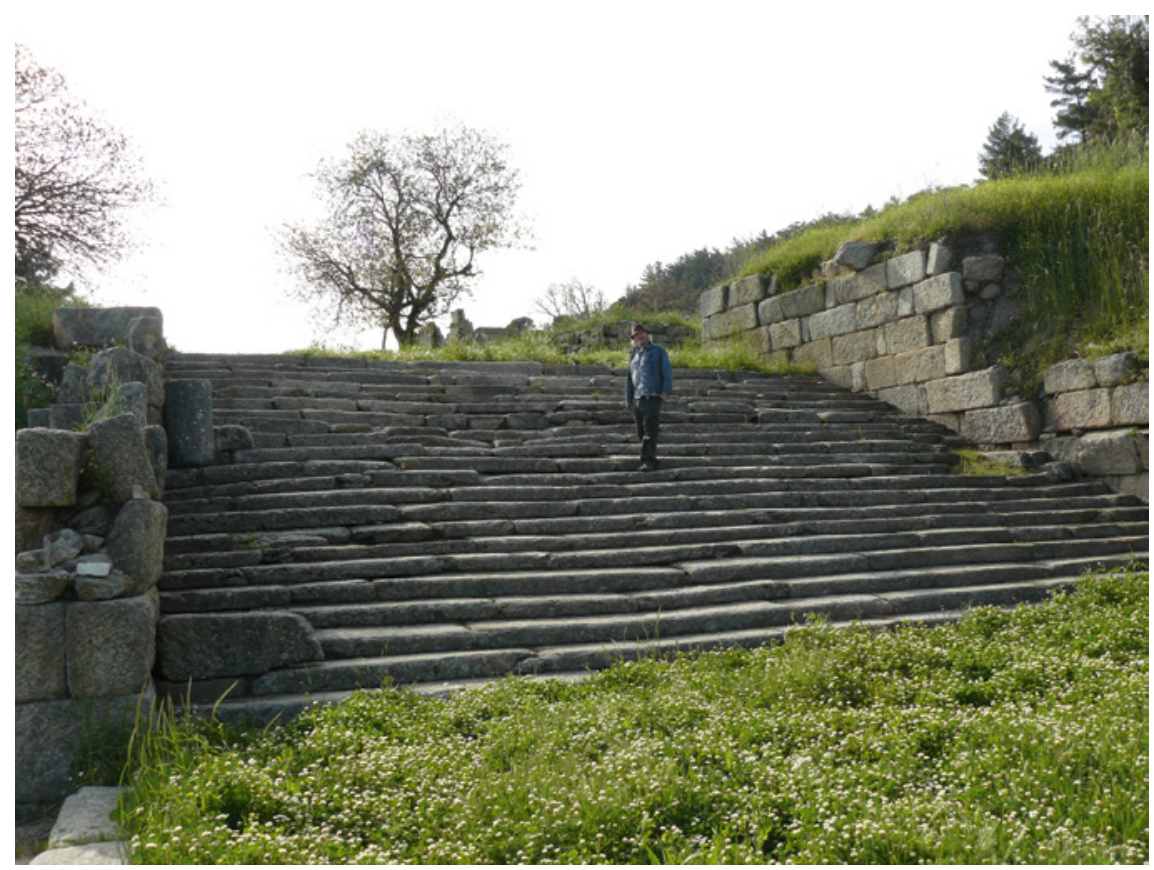

FIGURE 3.7 Labraunda. Monumental staircase leading to the Middle Terrace PHOTO AUTHOR 2008

for some kind of ritual performance with perhaps the East Propylon functioning as backdrop. ${ }^{87}$

Characterized by dining facilities, the middle terrace is closed off to the east by a portico, the East Stoa (Figure 3.6), with six banqueting rooms at the back; each room could accommodate eleven couches for diners in symposium. ${ }^{88}$ Along the northwest end was a retaining wall with a large fountain, and at the opposite, western end of this terrace was the first of two andrones, as labeled by their architraves. These were sumptuous banqueting chambers, with plastered walls, mosaic floors and niches to hold sculpture, and have been suggested to have functioned as royal reception halls. ${ }^{89}$ Maussollos's andron

87 Hellström (2015), inspired by Nielsen (2002).

88 Hellström (1989b); the sixth room was postulated in Hellström (1991b), in which the structure in 'Area W' was confirmed as a stoa with banqueting rooms (rather than part of a palace as was previously suggested). He considers that since each couch could have held two people, then 132 people could dine simultaneously in the East Stoa, Hellström (2011a), 153-154.

89 Carstens (2009), 85-89, 94-10o draws an analogy between Labraunda and Near Eastern palaces, noting the importance of royal receptions combined with banqueting, which she aptly calls "dining in paradise" (p. 88; also Karlsson (2015a)); she considers their use as 
(Andron B) would have been one of the first visible structures from the sacred way. A second andron (Andron A) built by Idrieus was positioned higher up on the terrace behind the temple; it is still visible today and was initially taken by the early explorers to be the main temple (Figure 3.2). ${ }^{90}$ Practically overshadowing the temple itself, these grand structures were both built in a mixture of orders, with Ionic columns standing in antis below a Doric entablature. ${ }^{91} \mathrm{~A}$ sculpted male bearded sphinx was found near Andron B, probably one of a pair that was set as corner akroteria on the roof, clearly displaying Achaemenid influences. ${ }^{92}$

Each andron was spacious inside, with large airy windows. Those of Andron A measure c. $1.85 \times 1.05^{-1.10} \mathrm{~m}$ (Figure 3.8); the only fully preserved window of Andron $B$ is in the crosswall, measuring $1.62 \times 1.05^{-1.07} \mathrm{~m}$, the windows in the south wall were probably similar in size. ${ }^{93}$ There was room for about 20 dining couches along the sides and the rear, where a large niche, two meters above the floor, is presumed to have held statues of Zeus and members of the dynasty. ${ }^{94}$

meeting place for Karian federations, Carstens (2009), 75-100; also Hellström (1989a). The royal setting is more extensively discussed in Henry (2017), who sees the complex as part shrine, part palace. Isager and Pedersen (2014) discuss the andrones in Labraunda in connection with a Hekatomnid andron of Zeus Akraios in Halikarnassos, known only from a dedicatory inscription. For the sumptuous materials, Henry et al. (2018), 288 and 293.

9o Idrieus's andron is the target of the 'Conservation Project of the Andron A in Labraunda', a project by the Institute Français d'ëtudes Anatoliennes (IFEA) and the Middle East Technical University in Ankara (METU); see Henry et al. (2013), 310-322 and Henry et al. (2014), 256-262.

91 Hellström (1996a), 136, describing Maussollos's andron, notes how the temple-like character emphasized its function for "super-prestigious, ritual banqueting." Also Karlsson (2013a).

92 Gunter (1989), 92-94 with images; Carstens (2010) and (2011), 126-129; Held (2011). The combination of Ionic and Doric orders with Achaemenid-like sculpture in any event reflects cross-cultural influences and may well indicate the international ambitions of the Hekatomnids, Hellström (1996b), 136; Held (2011); Karlsson (2013a).

93 The extant dimensions of the windows of Andron A are c. $1.7 \times 2.1 \mathrm{~m}$, Hellström (2007), 131-132. The sizes given here reflect the viewable area, reduced by the window sill, frame and revetment. My thanks to Pontus Hellström for this information (pers. comm. o6.07.2011).

94 On the andrones in general, see Hellström (2007), 90, 131-132. Idrieus's andron was similar to that of his brother Maussollos; both were larger than the temple of Zeus, with raised floors around the edges (1 m in width), see Hellström (1989a), 101-104. Hellström (1996a) argues that the andrones represent a new "élite, non-egalitarian way of banqueting" as intended by the satraps, see also Hellström (2009), 271 and (2011a). Whether the (presumed) dynastic sculpture in the niches represents ruler worship may be debated, yet we know of an altar to Maussollos at Labraunda from I.Labraunda 49 and 134, Isager and Karlsson (2008); Idrieus also received cult honors at Iasos as Zeus Idrieus, Fabiani (2015) and Carbon (2016). Also Maddoli (2010) on the Maussolleion at Iasos. 

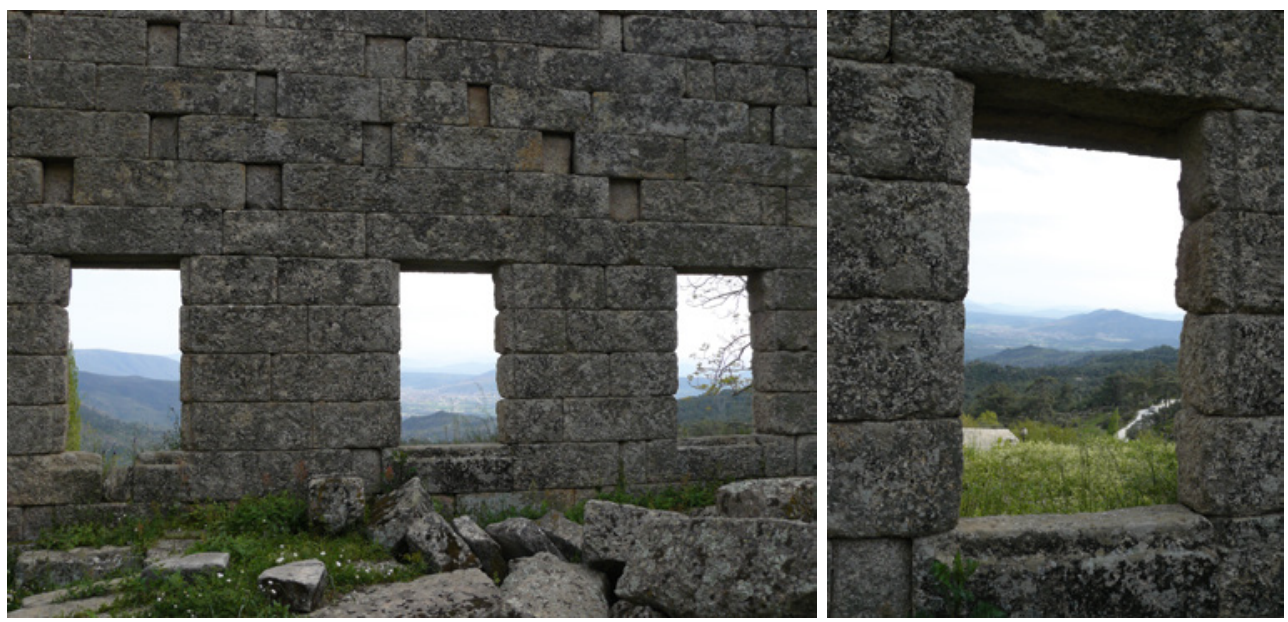

FIGURE 3.8

Labraunda. View towards Mylasa and the southwest framed by the windows of

Andron A; on the right, the view through the central window towards Mylasa, the Sodra Dağı, and part of the sacred road

PHOTOS AUTHOR 2008

While the middle terrace was designed for formal ritual dining, the upper terrace immediately east of the temple remained the core ritual space at Labraunda (Figure 3.9). One might envision the ensemble below as a grand prelude towards this climax, a concept that would become more widely applied in the Hellenistic period. ${ }^{95}$ The terrace was likely approached through a path requiring a couple of switchbacks before one made the final approach from the east and enjoyed a full view of the temple with Idrieus's andron in the background. The north side of the terrace was articulated by the Stoa of Maussollos, entirely rebuilt in the imperial period as the Stoa of Poleites (North Stoa, Figure 3.6). ${ }^{96}$

95 Such as the Asklepieion on Kos, Pedersen (1991), 114-115.

96 The North Stoa was dedicated by the priest Poleites (I.Labraunda 23), but re-uses stones bearing Maussollos's dedication of a stoa (I.Labraunda 13). This led Westholm to interpret this as a Roman reconstruction of Maussollos's stoa (Westholm (1963), 106); this view is followed by Crampa in his discussion of I.Labraunda 13. Hellström, however, considered the possibility of two different structures in Hellström (1991a), 299-300, 304 n. 40, since the Roman inscription mentions the dedication of the stylobate, columns, and entablature; F. Tobin observed that the stylobate of the North Stoa is Roman, Henry et al. (2014), 269. Liljenstolpe and von Schmalensee (1996), 146, however, argued in favor of Westholm's postulation Poleites's reconstruction of the Stoa of Maussollos and that is now the accepted view, e.g. Hedlund (2014), 62, Henry (2017), 555 . 


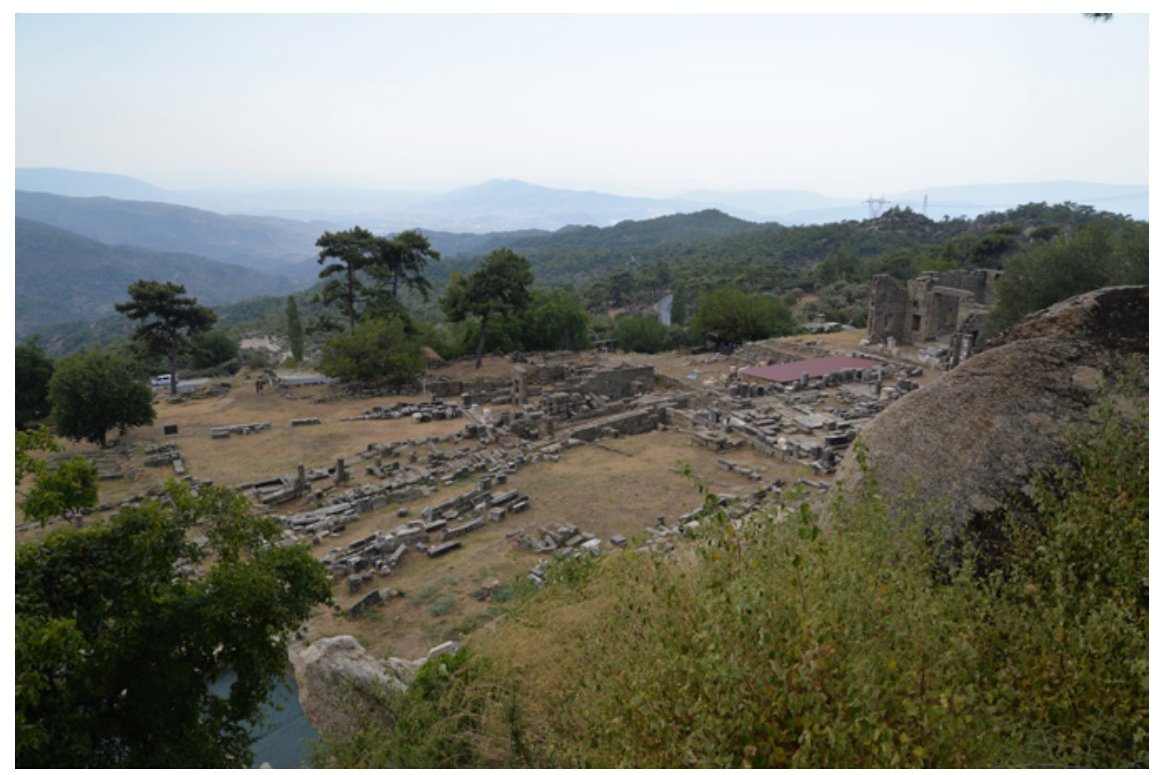

FIGURE 3.9 Labraunda. View of the Temple Terrace from the Split Rock. The temple is to right Рното AUTHOR 2019

Idrieus had the temple rebuilt. ${ }^{97}$ Constructed on the foundations of its Archaic predecessor, the squat cella was now extended with a (very shallow) opisthodomos, and fitted with a $6 \times 8$ column peristyle in the Ionic order on a threestep krepis. ${ }^{98}$ The stylobate made the footprint of the temple larger than that of the andrones, but the cella, roughly of the same dimensions as its Archaic

97 I.Labraunda 16 is a dedicatory inscription from the architrave of the temple.

98 Hellström and Thieme (1982), on the temple in general. The dimensions of the peristyle are presumed to have been restricted by the altar before the entrance, Hellström (2007), 111 and Henry (2017), 554-555. This would be an early example of an Ionic temple with an opisthodomos, borrowed from the Doric order. This combination is more well-known from the Athena temple in Priene (350-33о вС), of which Gruben states "Demgemaß erhält nun auch der Naos nach dorischem Muster symmetrische Fronten mit zwei Säulen zwischen den Anten. Damit begegnet zum ersten Male nachweislich der Opisthodom auf ostionischem Boden," Gruben and Hirmer (1966 [1986]). Yet the temple of Zeus Labraundos, dedicated by Idrieus, is either co-eval with the Athena temple, or earlier. This combination is attributed to Pytheos, who also co-designed the Maussolleion in Halikarnassos; as architect for the Hekatomnids, it is likely that he or his team designed the temple at Labraunda as well, Hellström (2007), 117. For possible connections between Pytheos and Hekatomnos at Mylasa, via the poem by Hyssaldomos, discovered in the Uzunyuva excavations, see the intriguing discussions in Marek and Zingg (2018). 
predecessor, is much smaller. Had it not been for the peristyle, the temple would have been entirely overshadowed by the rest of the monumental architecture at the complex. ${ }^{99}$ This is especially true when viewing the sanctuary upon approach from the road (Figure 3.3); the temple occupies a much more central place, however, when seen from the temple terrace and the split rock above (Figure 3.9).

Behind the temple was the building complex designated as 'Oikoi', perhaps an administrative structure or treasury, apparently reserved for the priests. ${ }^{100}$ Immediately in front of the temple is a small squarish foundation, a little over $3 \times 3 \mathrm{~m}$, from the Archaic period that is interpreted as an altar. This function has not been confirmed by finds, and the proximity to the temple seems like a fire hazard. ${ }^{101}$ Nonetheless, a parallel may be found in the altar and temple of Zeus Lepsynos at nearby Euromos. ${ }^{102}$ As observed above, this area certainly does seem to be the architectural, and ritual, focus of this terrace and one might expect a more prominent altar at the center of such a grand complex, although monumental altars were more common in the Hellenistic era. ${ }^{103}$ Labraunda

99 Pontus Hellström once suggested that Idrieus intentionally added the peristyle in order to shift the architectural balance at the sanctuary back towards Zeus, Hellström (1996b), 137-138. The design of the sanctuary indicates a unified plan, with Idrieus's dedications being carried out while governor of Mylasa and after Maussollos's move to Halikarnassos, Hellström (2011a), esp. 154-155. The original height of the temple is estimated to be two meters lower than Andron A, see Henry (2017), 556-557.

100 The identification of this structure is based on the architrave dedicatory inscription by Idrieus, I.Labraunda 17, discussed below; see also Hellström (2007), 119-125: "The function of the Oikoi Building is not evident. It has been supposed that it served as a building for the priests of the sanctuary and as an archive, maybe a prytaneion (council house). It may also have served for ritual meals, in the same way as the two andrones and the East Stoa. A main purpose for the Oikoi Building may, however, have been as a treasury for the safe-keeping of valuable gifts to the god."

101 Excavations revealed no artifacts, pottery, votives, ash or bones, yet the Archaic mudbrick altar was clearly no longer functional (as it was partly built over by the North Stoa). Hellström and Thieme (1982), 24-25 suggested this may have been a thesaurus or a bothros, although the lack of finds remains similarly problematic. Current opinion supports a view of the small structure before the temple as the altar: Hellström (2007), 111; Henry (2017), 554-555. The location and ongoing use of this structure may well have determined the extent of the peristyle, as suggested in Hellström (2007), 111 and Henry (2017), 554-555.

102 D. Laroche in Kizll et al. (2018), 182-184, who proposes a construction date of $330-300$ BC for the altar, predating the temple. This would be similar to Labraunda, where the square structure was farther from the Archaic temple, Thieme (1993), 55, Fig. 8, and may well have determined the extent of the peristyle as suggested in Hellström (2007), 111, and Henry (2017), 554-555.

103 Balthis (2006); Linfert (1995). Kuhn (1985), 258, believes a (larger) altar would have been on this terrace due to the prominence of the temple terrace behind. 
held at least one other altar that was still known and presumably in use in the Hellenistic period: that for Maussollos, as inscriptions testify. ${ }^{104}$

Nearly all of the new or renovated structures were marked with dedicatory inscriptions by either Maussollos or Idrieus on their architraves above the entrances where everyone could see them. In and of itself, this phenomenon of ostensible dedication, with the name of the ruler directly connected to the god, set a precedent that would be followed in the Hellenistic era. ${ }^{105}$ Idrieus inscribed his dedications on his andron (A), as well as the Temple, the 'Oikoi', the South Propylon, and probably the 'Doric Building', likely a fountain house. ${ }^{106}$ Unlike Maussollos, Idrieus seems to have deliberately included the

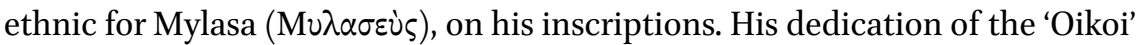
best illustrates this: Idrieus, son of Hekatomnos, Mylasan, dedicated the oikoi to Zeus Labraundos. ${ }^{107}$ This added emphasis on Mylasa has been interpreted as reflecting his role as hyparch of Mylasa during Maussollos's reign as satrap. ${ }^{108}$

The royal andrones have with reason attracted quite a bit of scholarly attention. ${ }^{109}$ Of particular interest is Maussollos's dedication of his andron (B): Maussollos son of Hekatomnos dedicated the andron and what is inside to

104 Isager and Karlsson (2008); Ameling (2013).

105 E.g. Alexander the Great's dedicatory inscription on the temple of Athena in Priene (Roels (2018a), 242-246) or the architraval dedication of Philetairos on the temple of Meter Theon at Mamurt Kale (Williamson (2014a)). The influence of the Hekatomnids on dedictatory inscriptions is further discussed in: Hornblower (1982), 274-293; Umholtz (2002); Isager (2011); Roels (2018a), 291; Mylonopoulos (2019).

106 Idrieus's dedications: I.Labraunda 15 (Andron A); I.Labraunda 16 (Temple); I.Labraunda 17 ('Oikoi'); I.Labraunda 18 (South Propylon); I.Labraunda 19 ('Doric Building'). Idrieus's andron was a room with a view, like that of his predecessor, but had windows along both flanks of the structure; Williamson (2014c).

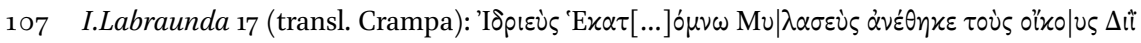
$\Lambda \alpha \mu \beta p \alpha u ́ v \delta \omega[\ldots]$.. See also Debord (1999), 404.

108 Pedersen (2009), 334-337 and Hellström (2011a), 155. Hellström observes that if this is correct, then the chronology of the architecture should be moved up somewhat since Idrieus probably finished Labraunda after Maussollos's move to Halikarnassos, rather than after his death $353 / 2$ BC, as is traditionally held. Earlier interpretations of Idrieus's inclusion of the Mylasan ethnic include Hellström (1996b), in which it is seen as being indicative of a more inward turn in policy, focusing on Karia, rather than the wider international political circle, as Maussollos had done. This concords with Crampa's view, I.Labraunda (vol. 2) p. 6.

109 Pontus Hellström has published extensively on these extraordinary structures: Hellström (2011a), (2009), (1996a) and Hellström and Blid (2019). They are further incorporated in studies, including among many others: Henry (2017); Hedlund (2014); Carstens (2011); Pedersen (2009). The dining function is further discussed below. 
Zeus Labraundos. ${ }^{110}$ Like Andron A, Maussollos's andron was certainly a 'room with a view' as it was atypically fitted with large windows. ${ }^{111}$ Yet Maussollos's banqueting hall, built first, has windows on the south side alone, framing the breathtaking panorama across Mylasa and a large part of Hekatomnid territory beyond that - surely this view was one of the most valuable things inside the andron (Figure 3.5 and frontispiece). ${ }^{112}$ The same panorama could be enjoyed from most of the sanctuary, but it is significant that it was occasionally set within in a cadre, as was literally the case through the andron's windows. The linear space of this view, visually connecting the sanctuary with the city and the surrounding landscape, was thus put to use in a ritual context - in this case, the act of dining by the elite who probably controlled much of Mylasa. In a broader sense, the view was also framed by the terrace architecture in general, a concept more common in later complexes of the Hellenistic period. ${ }^{113}$ At Labraunda, one would regularly find oneself surrounded by walls except for the open south side towards Mylasa. Visually stressing the view in these contexts is an example of how ritual space could be used in a directive, linear way. It not only creates an intimate bond between the worshiper and the wider and distant region, it also steers the gaze of the viewer, in this case towards Mylasa.

The sanctuary at Labraunda thus underwent a radical metamorphosis in the fourth century BC at the hands of the Hekatomnids. Architecturally speaking, this transformation from a relatively modest cult place that focused on

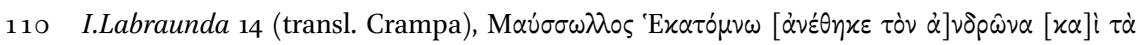

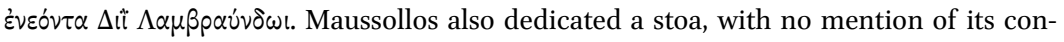
tents, I.Labraunda 13, [M] inscribed on one of the antae). Idreius's dedication of his andron (A) also makes no

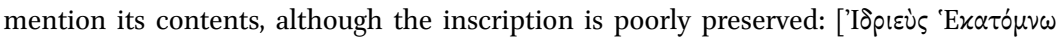

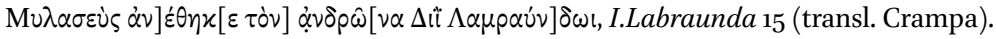

111 Laumonier relates the windows of the andrones to Zeus's role as a sky-god, Laumonier (1958), 99; on Zeus Labraundos as a weather god, see also Karlsson (2013c).

112 I develop this argument more fully in Williamson (2014c).

113 Fehr (1970), 38-39: "In Labraunda begegnet uns ausserdem eine Vorstufe zu den pergamenischen Terrassenhallen ... die pergamenischen Terrassenhallen übernahmen offenbar den karischen Baugedanken des auf einer Mauer ruhenden Stylobats und kombinierten ihn mit der den Griechen seit langem vertraueten Stoa am Rande eines Platzes," referring to Martin (1951), 147f. Also Pedersen (2004), 409: "It is suggested that some technical details of the Philetairian fortifications were probably invented in Karia at the time of Maussollos and that perhaps even the great terrace architecture of Pergamon may owe something to the 4th cent. Karia as suggested by R. Martin in 1974," see Martin (1974); see Williamson (2014a) on Mamurt Kale. Pedersen had previously observed that Hekatomnid terrace architecture, which created a setting becoming to gods and rulers, may well have been a conceptual prototype for Hellenistic architectural design, such as the terraced Asklepieion on Kos and the layout of Pergamon itself; Pedersen (1991), 114-115. See also Lehmann 1954, on temples being embedded within a larger 'baroque' complex. 
natural features into a monumental complex of successive enclosed spaces, foreshadowing architectural concepts that would become much more common in the Hellenistic period, was the most significant turning point in the history of the sanctuary.

Although Hekatomnid architecture remained intact and in use throughout the Hellenistic period, scholars long held that the only addition was the fountain house on the middle terrace. ${ }^{114}$ In light of the conflicts between the priests and the polis as recorded in the inscriptions at the site, Labraunda was considered to have undergone a period of stagnation after the passing of the Hekatomnids until the Roman era when architectural activity resumed. ${ }^{115}$ Recent excavations, however, tell a different story. The sanctuary appears instead to have been in continuous and intensive use throughout the Hellenistic period, an image testified by the ceramics, but now also corroborated by the architectural record. ${ }^{116}$ One of the largest buildings at the site is a Doric two-aisled stoa in the middle of the temenos and tentatively dated to the third to second century BC (although it was rebuilt in the second century AD). ${ }^{117}$ Building $\mathrm{M}$, as it is called, is situated along a narrow terrace above and behind the earlier Hellenistic fountain house and below the temple terrace. Although its function and relation with these structures is not yet entirely clear, it was the most conspicuous structure of Hellenistic Labraunda and is surely key to understanding the sanctuary in this era. With its location on a 'ledge' between the temple terrace and the area before Maussollos's andron, it would have provided a sheltered position from which one could enjoy the shrine and its scenery. Perhaps this was an act of the democratic polis, in affording an articulated view across the landscape below to the public at large, not just for those that were invited

114 Westholm interpreted the fountain as being Roman, Westholm (1963), 94, but Hellström sees more Hellenistic parallels and also the orientation of the fountain which suggests that it predates the wall, Hellström (1991a), 304.

115 Westholm (1963), 112 on Period v, the Hellenistic period: "Although various conditions in Labraunda are mentioned in a number of inscriptions from the Hellenistic time, there is no one of the excavated structures which was built in that period. The activity of the Hekatomnides was apparently sufficient for a long period ahead." Hellström (1965), 1-3 and Hornblower (1982), 311-312 see this as a period of decline. Hellström's hypothesis on Labraunda as 'memory theater', Hellström (2009), is based on the presumed lack of building activity, which he considers intentional rather than consequential. Since then some Hellenistic construction been identified, yet this perspective is still crucial for understanding Hellenistic Labraunda, see also Williamson (2013d). The imperial period saw several additions to the shrine, including Andron $\mathrm{C}$ and the baths.

116 See the preliminary reports in Anatolia Antiqua, especially from 2013 and on.

117 Blid and Hedlund in Henry et al. (2013), 327-336 and in Henry et al. (2014), 294-304. Perhaps future investigations will reveal whether any inscriptions were placed in this stoa; it would have been an ideal location. 
to dine in the elite andrones. In any event, this structure was enlarged in the imperial era and given a second storey, similar to Poleites's stoa. ${ }^{118}$

Another monumental feature is the structure in the area southeast of the temenos known as the Hypostyle Building. Once thought to be Roman, this is now identified as a fountain house from the Hellenistic period, rebuilt in Roman times. ${ }^{119}$ Stoa B/Y, immediately south of Propylon $\mathrm{Y}$ and east of Building M, similarly knew an initial construction phase in the Hellenistic period with a renovation phase in Roman times. ${ }^{120}$ The Roman phases of these buildings shows poor construction that led to several repairs in later periods. ${ }^{121}$ This lower quality may be indicative of the resources available to the polis, but the very presence of such public facilities is nonetheless unequivocal testimony to the ongoing popularity of the shrine. The noteworthy desire for abundantly available fresh water is indicated by the construction of the hypostyle fountain house and the smaller fountain house on the middle terrace. A third monumental fountain house, similar to the one on the middle terrace, was discovered roughly $110 \mathrm{~m}$ northwest of the temenos and was partially excavated in $2013 .{ }^{122}$

Another spatial indicator of the continued popularity of the shrine is the erection of honorific monuments. Although the Hellenistic inscriptions at Labraunda are discussed in more detail below, the largest free-standing honorific monument at the sanctuary is the marble exedra at the east end of the temple terrace, possibly from the third century BC. The location next to Propylon Y makes this a choice spot, one of the first features of the sanctuary that would have been seen by visitors passing through this portal. Unfortunately we know very little about the exedra or whom it honored. Holes in the top indicate that nine bronze statues once crowned the structure. The inscriptions, however, bear only the name of an individual, Demetrios, son of Python, otherwise unknown. ${ }^{123}$ Although the provenance of the marble is unknown as of yet, it

118 Blid and Hedlund in Henry et al. (2014), 303-304.

119 F. Rojas et al. in Henry et al. (2016), 304-316.

120 Blid and Hedlund in Henry et al. (2014), 295; Hedlund's analysis showed anta blocks belonging to this structure bearing the inscriptions I.Labraunda 45 and 71 , providing a terminus ante quem in the Hellenistic period, Hedlund (2014).

121 Building M was "constructed in a haphazard way, which ultimately led to the collapse of the building," Blid and Hedlund in Henry et al. (2013), 327-336 and in Henry et al. (2016), 304. The Hypostyle Building was constructed on foundations that were "roughly cut, poorly joined and not clamped," Rojas et al. in Henry et al. (2016), 315.

122 O. Henry in Henry et al. (2016), 269-272.

123 I.Labraunda 29a-c; Crampa dates these to the third century вс based on the lettering. The exedra was excavated in the 1940 os but was cleaned in 2013 and published by F. Tobin in Henry et al. (2014), 269, Fig. 28. See also below, under Civic Decrees. 
is tempting to connect the construction of this feature with some of the finer architecture that Mylasa was known for. ${ }^{124}$ There is an abundance of marble in the area, including the Sodra Dağı which towers above the city and was quarried in antiquity for its white marble. By the first century BC, Strabo wrote that because of the quarry, Mylasa, 'as much as any other [city], is in every way beautifully adorned with porticoes and temples'. ${ }^{125}$ It would have made sense to extend the same kind of garniture to the sanctuary, if it was an important public space for the polis. From the preliminary results it would seem that in the Hellenistic period there was a mixture of functional public buildings hastily constructed in local gneiss, such as the Hypostyle Building, and elegant privately funded features built in fine marble, like the exedra - hopefully future investigations at the shrine and in the environment of Mylasa will shed more light on this construction hybridity in the Hellenistic period.

Besides these additions, however, the Hekatomnid design was left intact and the buildings were maintained and used. In this way the legacy of the Hekatomnids lived on, along with their power which the architecture continued to emit through its resonance with the landscape. The excellent facilities would thus have been a perfect match for the needs of the Hellenistic polis, which now used the sanctuary to follow its own agenda in propagating Mylasan identity.

\subsubsection{Public Space - Concentric and Linear}

One of the main goals of the Hekatomnid renovations at Labraunda was obviously to create a place that could host considerably large audiences; as mentioned above, the leveled surface area was considerably expanded to $7200 \mathrm{~m}^{2}{ }^{126}$ The terraces allowed not only for good access, directing the flow of traffic via a gentle serpentine route up the hill and along the various facilities (e.g. banqueting areas, fountains), but also for segregate gatherings, both inside and outside of the sanctuary. The clearest example of concentric space is found in the stadion, constructed west of the shrine for the games (discussed further below).

The retaining wall south of the propylaia must have acted as a kind of 'vestibule' while the festival crowds were channeled through the gateways to the sanctuary. The wide terrace between the East Stoa and Andron B was then a second reception area, after the monumental staircase, and before

\footnotetext{
124 The marbles of Labraunda are being examined by A. Freccero, Henry et al. (2014), 276-277.

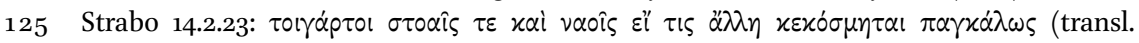
H.L. Jones (1929) The geography of Strabo, LCL 223).

126 Pedersen (1991), 99, Fig. 99.
} 
approaching the temple area - both of these areas allowed for a large part of the festival crowd to congregate during their stay at the sanctuary. The quantities of tableware and lamps indicate that Labraunda was in fact regularly and intensively occupied. ${ }^{127}$ With its ample facilities, water supply, and wide and varied spaces, a large gathering could easily have camped out at the sanctuary for the greater part of a week. ${ }^{128}$

On the next terrace, the area in front of Maussollos's andron may also be identified as concentric space. Building $\mathrm{M}$, a stoa elevated on a higher plane that looks out across the shrine, also faces this space. Although not round, the clear focus of these areas with ample room for spectators corresponds with Chwe's idea of an 'inward-facing circle', allowing for all the participants to not only view the central ritual, but also to observe each other viewing the event. ${ }^{129}$ As he states, this is one of the prime ways to generate common knowledge, which is the basis for group cohesion and the goal of most public (i.e. 'rational') rituals.

The temple terrace, with its surface area of roughly $1000 \mathrm{~m}^{2}$, had an internal visual focal point in the central area, framed by the temple and Propylon $Y$ (and later the North Stoa) and should be considered as concentric ritual space. ${ }^{130}$ Monuments moreover identify critical spots, and these were initially concentrated on or around the temple. The space contained within the temple terrace held a statue dedicated by Hekatomnos, founder of the dynasty, and another of Ariarames, the son of (a) Maussollos. ${ }^{131}$ Two other inscriptions from the fourth century were also found on the temple terrace; these include fragments of a stele bearing a list of names, perhaps envoys, and a plaque that may have been a decree by a certain Hekatomnos. ${ }^{132}$ With its focus on ritual, but also on dynastic members, this terrace was certainly the primary ritual and public space of this sanctuary. ${ }^{133}$ The locations of inscriptions and the exedra monument show that the temple and the temple terrace continued to be used as

127 Hellström (1965), although in this publication he argues for a decline in the Hellenistic period, p. 13; this is discussed below under Festivals.

128 The festivals of Zeus Labraundos lasted for perhaps up to five days, see below.

129 Chwe (2001), 30-33, discussed in Chapter 2.

130 Discussed in more detail in Williamson (2014a).

131 I.Labraunda 27 and 28, respectively. On the identity of Ariarames, see Crampa's discussion on p. 28-29; he tentatively dates the inscription on this statue base (I.Labraunda 28) to the end of the fourth century вс.

132 I.Labraunda 67 and 83, respectively. A third decree, I.Labraunda 40, was found reused in a later floor behind Andron B; this was a proxeny decree issued by Maussollos and Artemisia for the people of Knossos; unfortunately its original setting is unknown.

133 See also Williamson (2013e) on Labraunda as public space. 
important public spaces in the Hellenistic period (Figure 3.6, Areas A-C, E and $G)$.

Two more critical spots in the sanctuary may be identified through inscriptions in this period. One was the South Propylon, particularly in the third and second centuries BC, when it was marked by a number of documents, including the citizen's oath of Mylasa (Figure 3.6, Area F). ${ }^{134}$ This was of course the end of the processional route from Mylasa, and thus the hinge connecting the world of the polis to the realm of Zeus Labraundos. A second critical spot was the anta of Maussollos's andron (Figure 3.6, Area D), which bore the decree by Philip v stating that Labraunda belonged once and for all to Mylasa. ${ }^{135}$ This andron, like that of Idrieus, was one of the most representative interior spaces at the sanctuary, with monumental windows that 'framed' Mylasa. Inscribing this final decision here added emphasis to the visual link with the polis that had already been laid.

The hillside of Labraunda afforded a panoramic view across the landscape to Mylasa and beyond. The architectural construction on the terraces shaped this view and connected it to ritual space at the sanctuary; the windows in the andrones narrowed the focus even more, by literally clustering parts of the landscape together with Mylasa at the center. Using ritual architecture in this way to define the view moreover instructs the eye as to what it is seeing within a ritual context. ${ }^{136}$ Emphasizing such sightlines brings faraway places 'within reach' since two (or more) visual points are comprehensively connected, crossing space and time with a single movement of the eye. It further helps create a mental spatial hierarchy in the landscape by defining this particular view as a 'region', from which the relationships in the rest of the landscape can or should be understood. ${ }^{137}$

A more kinetic use of linear space in a ritual context is of course the processional route, which connects two (or more) places by physically crossing space and time in a ritualized way. This route is certainly one of the most tangible ways of connecting the sanctuary to the city.

134 Other than Idrieus's architrave inscription for the South Propylon, I.Labraunda 18, all of the inscriptions posted here date from the third (I.Labraunda 46, Antiochos III letter of protection from $203 \mathrm{BC}$ ) or second centuries BC: I.Labraunda 68 (a list of names from c. 200 BC), I.Labraunda 47 (the Mylasan civic oath), I.Labraunda 9 and 134 (honorific decrees for Olympichos, re-cut in the second century вС).

135 These inscriptions are further discussed below.

${ }_{13} 6$ Fehr (1970) explores the development of emphasized sightlines prior to the Roman period; see also Williamson (2014a).

137 Discussed in the section Spatial memory and visual regions, in Chapter 2 under Approaches from outside the box. 
4.1.3 Sacred Road

One of the first construction works by Maussollos would actually have been the sacred way linking this sanctuary to Mylasa. The road runs more or less directly north from Mylasa, crossing the fertile plain of the Sarıçay en route to the Çomakdağ ridge and continuing on into the mountains and wilderness areas, where it is punctuated by springs and tombs, but also by the fortifications discussed above. ${ }^{138}$ Some 14 kilometers long, this processional road is $7-8$ $m$ wide and was paved, presumably for much of its course (Figure 3.10). Several stretches are still intact and it is partly followed by the modern road, especially in the mountainous areas from the modern village of Kargicak up to the sanctuary. A tremendous effort went into the construction of this road: a number of terraces and structural supports were built to make it as straight as possible, and its surface was made firm and smooth with large flat slabs. This would

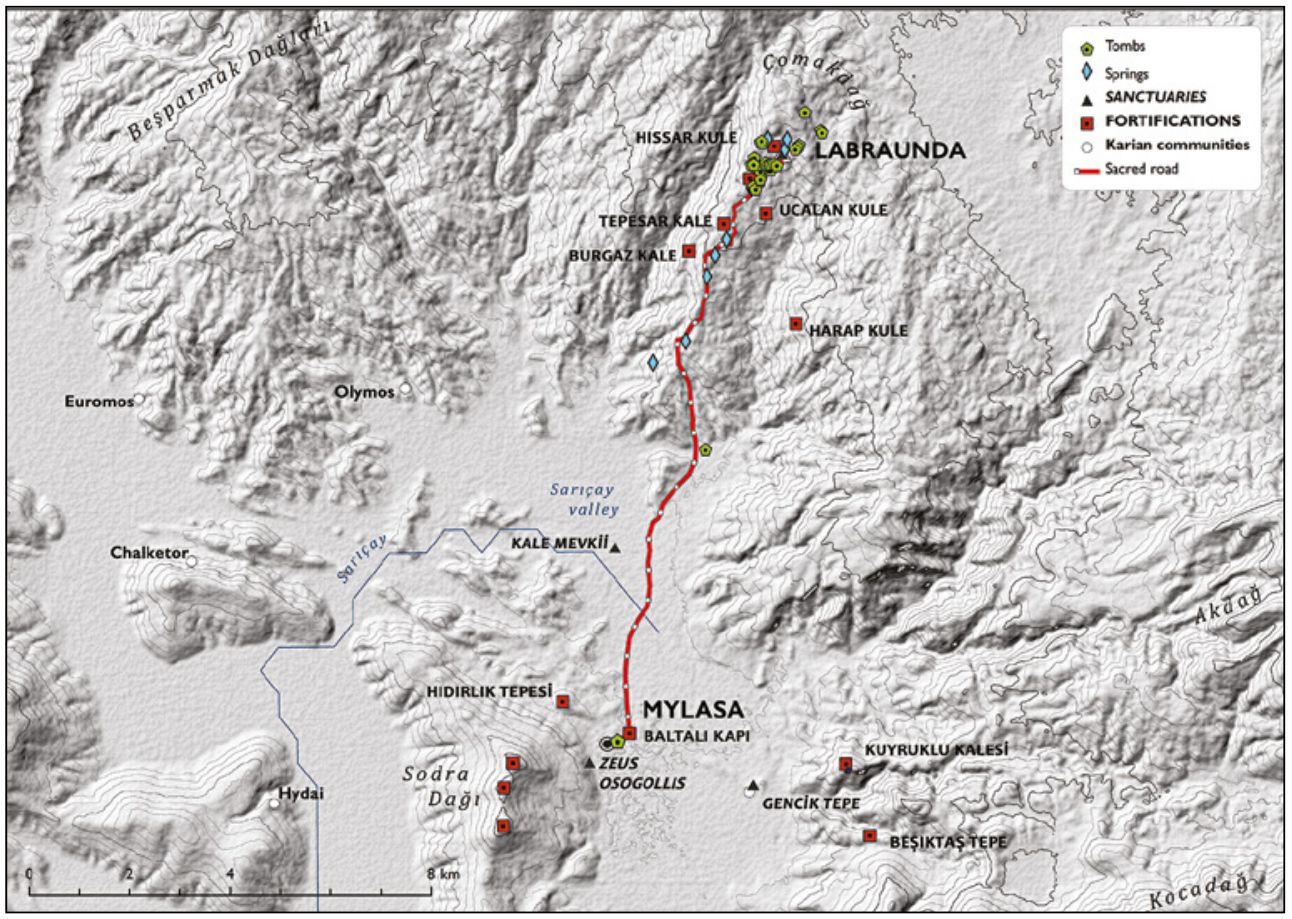

FIGURE 3.10 Route of the sacred road from Mylasa to the sanctuary of Zeus at Labraunda. Trajectory after Karlsson (2010), Fig. 7, and Baran (2011)

138 Baran (2011), 52-66 discusses the sacred way in detail; the 61 tombs discovered so far, ranging from Classical to Late Roman are studied by O. Henry in Karlsson et al. (2008), 116-121; Durusoy (2014). 
have facilitated the transport of the construction material to the site, and is held by some to be the main purpose for the pavement. ${ }^{139}$ Nonetheless, this road may well have been the most attractive and monumental route of its day, and with springs at regular intervals it made for a fairly comfortable journey. ${ }^{140}$

The relatively high concentration of watchtowers, in visual range with each other and the Akropolis Fortress in a 'watch-and-warn system', must also have ensured safe passage along this road, both during the festivals as well as for regular traffic (Figure 3.4). ${ }^{141}$ Most of these towers have now been excavated, and their finds and construction technique indicate an origin in the Hekatomnid period for the Akropolis Fortress, Tepesar Kale, and Burgaz Kale, which was the most southern fortress in this system. In the third century the chain seems to be expanded with the watchtowers of Ucalan Kule, Kepez Kule, and farther to the south Harap Kule, as well as expansions to the Hekatomnid fortifications. ${ }^{142}$ Labraunda is situated on the main pass to the north that also leads to the plain to the east, the Hayrrlidere valley, and the area of Lagina, discussed in Chapter 5. The fortifications served to protect the sanctuary as well as this road itself, which not only carried pilgrims towards the sanctuary of Zeus but also gave critical access to north and central Karia. ${ }^{143}$ Recent excavations show their ongoing use in the Hellenistic period, especially at the Akropolis Fortress, which may well have been the fortification known as 'Petra' and used by Olympichos. ${ }^{144}$

139 On the road see Westholm (1963), 9-10 and Baran (2011), $5^{2}$ “... it might be suggested that the Hekatomnids built a substantial road which had stone paving, small bridges for gully drainage, and strong retaining walls in order to ease transportation of marble to the site during the building activity and the increase the accessibility for the pilgrims and visitors of the sanctuary." See now E. Durusoy and A. Güliz Bilgin Altınoz in Henry et al. (2013), 342-350, with a map of the features in Fig. 87; also Durusoy (2014), Fig. 12.

140 Karlsson et al. (2008), 129, and Baran (2011), 52, 90-94 who lists 42 ancient fountain houses near the sacred road, the construction of which generally points to the Hekatomnids.

141 Karlsson et al. (2008), 111-116; Karlsson (2011), 217, 233. Also on the Akropolis Fortress, Baptiste Vergnaud in: Henry et al. (2013), 285-298; Henry et al. (2014), 280-292; Henry et al. (2015), 317-330; Henry et al. (2016), 397-412; Henry et al. (2017), 215-221.

142 The fortifications of Burgaz Kale, Tepesar Kale, and Ucalan Kule, all on the east side of the sacred road, as well as the Akropolis Fortress, were excavated between 2007-2010. Burgaz Kale has been suggested as being near the frontier with Olymos, Pimouguet-Pédarros (2000), 314. Kepez Kule has not yet been excavated; for Harap Kule, Karlsson (2011), 217, 228. The Akropolis Fortress was also intensively used in the Hellenistic period, B. Vergnaud in Henry et al. (2015), 280-292), and in the Byzantine period, see Lars Karlsson's historical overview of the strategic location of Labraunda, Karlsson (2011), 247-25o.

143 The Hekatomnid fortifications near Labraunda are considered part of the wider network of a Karian defense system, Karlsson (2011), 248-249 and Pimouguet-Pédarros (2000).

144 I.Labraunda 4 and 6, discussed in more detail below. The excavations of the Akropolis Fortress show an intensive use in the Hellenistic period (mentioned above) although 
The processions from Mylasa were an integral part of the annual festival at the sanctuary. Little is actually known however about the composition of the processions, although with this being one of the major urban festivals of Labraunda it should be assumed that the entire citizen population took part in the event (at least those capable of making the journey). We should thus envision an annual trek of the population from Mylasa towards Labraunda, where they would camp out for the greater part of a week. ${ }^{145}$ Specific rituals involving the procession itself, such as the kleidos agoge at Lagina, ${ }^{146}$ are however unknown for the festival of Zeus Labraundos, yet the watchtowers, tombs, and monumental gateways at both ends indicate that this was a formal and solemn event. This continued well into the imperial period, as evidenced by the arched gate that marks the entry into the city, known as Baltalı Kapı after the doubleaxe carved into the keystone (Figure 3.11). This labrys, the identifying mark of Zeus, was noted by Abuzer Kızl to have eyes carved in relief in each blade the gaze of Zeus towards Labraunda, as he argues. ${ }^{147}$

The passage towards Labraunda gave pilgrims a clear view towards the sanctuary and the mountains to the north, but also guided them across diverse ecological and economic regions of the polis, from farmland and pastureland through the more remote mountainous regions, escorted all the while by a defense chain of command posts. Besides these spatial zones, the many tombs lining the road towards the sanctuary could remind pilgrims of the factor of time, as they passed by those who had gone before. Once at the sanctuary, they could look behind them to see Mylasa at the middle of a sweeping panorama that included much of this part of Karia (Figure 3.12). ${ }^{148}$ In this way, this monumental road transported Mylasans across the critical areas of their territory and provided them with a wide perspective of their own place in the world and in Karia, giving them a strong sense of community and identity. ${ }^{149}$

numerous sites in this rocky region were also called 'Petra'; I.Labraunda 137, line 9 speaks of a fortified 'Petra' in the territory of Olymos, discussed further in Henry and Aubriet (2015) and Carless Unwin and Henry (2016).

145 See below on the festivals.

146 The procession of the key from Hekate's sanctuary in Lagina to Stratonikeia, discussed in Chapter 5 .

147 Kizll (2009), with images.

148 But also note the approach to Labraunda from Alinda and Alabanda, via the eastern propylaea, via a road that was also at least partly paved; Westholm 1963, 110-112, and Hellström (2009), 270.

149 Chaniotis (1995), 160, “... unter den einzelnen Elementen des Festes die Prozession dasjenige ist, das die polis in ihrer Gesamtheit erfasst, repräsentiert und zu einer gemeinsamen Handlung bewegt; die Prozession ist das Spiegelbild der polis. In ihr findet sich die 


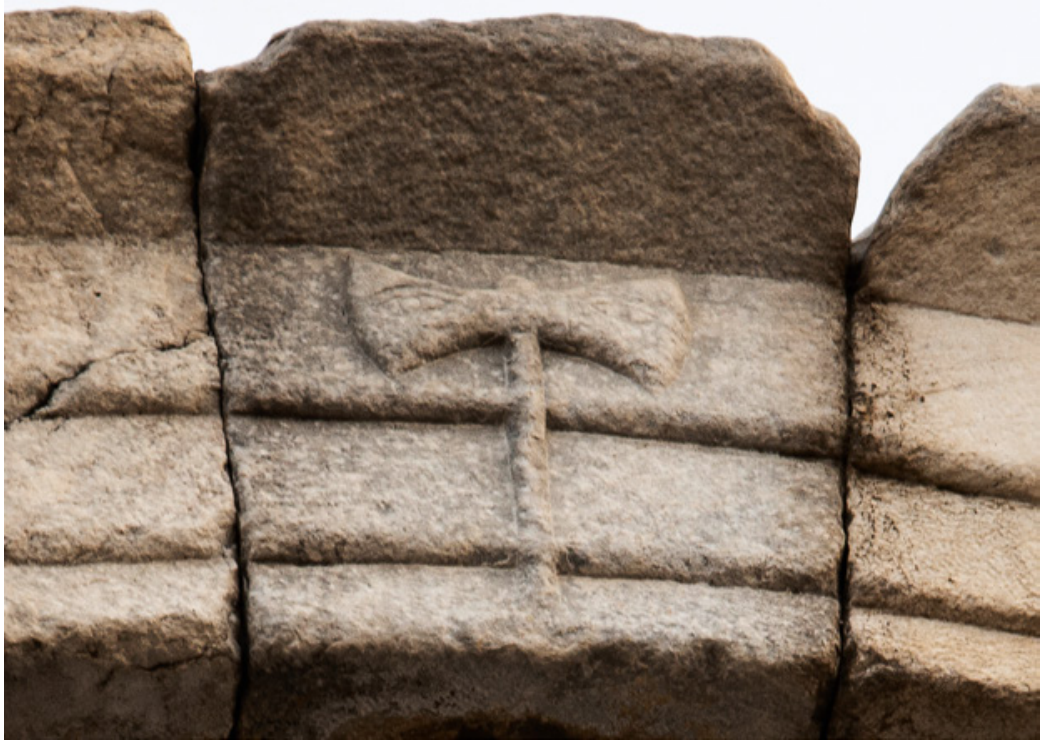

FIGURE 3.11 Mylasa. The labrys on the keystone of the Baltalı Kapı; note the eyes carved into the blades (see Kizll (2009))

PHOTO AUTHOR 2019

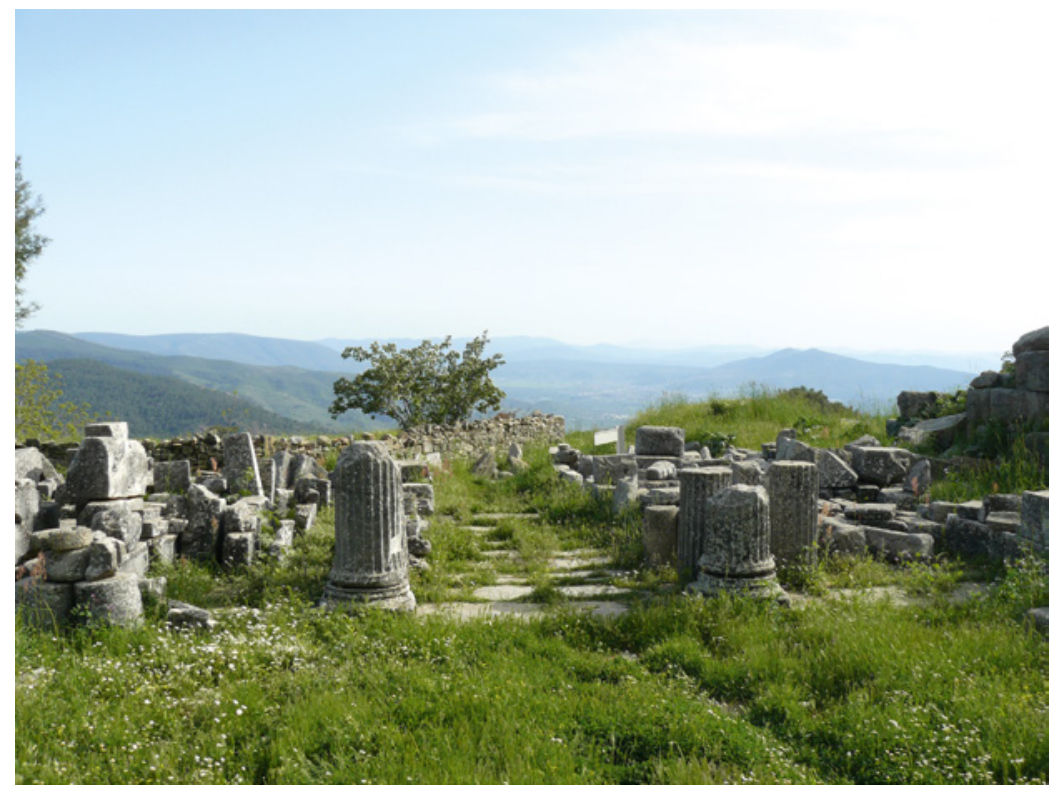

FIGURE 3.12 Labraunda. The South Propylon and the end of the sacred road. View towards the south and Mylasa, visible in the plain left of the mountain on the right side of the picture

PHOTO AUTHOR 2008 
To summarize, the natural prominence of Labraunda was exploited by the Hekatomnids in the Late Classical period when they radically transformed the shrine into a major political and sacred center that corresponded with their royal residencies at Mylasa and Halikarnassos. Greek, Achaemenid and Karian influences were intertwined on the cascading terraces, climaxing at the temple. The open area was spacious enough to accommodate a large crowd that could observe the main ritual as well as each other, and the splendid panorama, framed by architecture, across the Karian landscape, visually connecting the shrine with communities beyond, and Mylasa in particular. Monumental architecture served to foreground the shrine, thereby collapsing the distance between. Linear ritual space served this purpose as well via the processions that kinetically joined the polis to the sanctuary across different types of landscapes, economic zones, and along the many springs and tombs. In the Hellenistic period, the shrine was left intact and surely retained a sense of the power of the legendary rulers that had unified Karia. Pontus Hellström is right to depict Labraunda as a 'memory theater'. ${ }^{150}$ Inscriptions mark public and political flashpoints at the Hellenistic shrine. Zeus Labraundos had become an emblem for Karia, and it accorded well with Mylasa to imprint its urban identity upon this internationally recognized cult.

\subsection{Ritual Performance at Labraunda}

The radical reorganization of ritual space at Labraunda by the Hekatomnids must have coincided with a similar impact on the cult practices. ${ }^{151}$ The split rock clearly appears to have been the initial locus of cult with the dedications of votives. Especially interesting among these are the terracottas found in the early excavations depicting Kybele/Meter, dating from the Late Archaic and (Early) Classical periods, while the several girls carrying hydria (hydrophoroi koroi), and female protomes, dating from later periods as well, remind us of the female presence at the shrine. ${ }^{152}$ Several arrowheads from this era were also found on the temple terrace, mostly near the temple but also in the Mudbrick

gesamte Gemeinde zusammen, und zwar in einer Art, die jedem ihrer Mitglieder eine Rolle, eine Aufgabe, eine hierarchische Stellung zuweist."

150 Hellström (2009), 278. For a comparison, Horster (2013) on inscribed 'corporate' memories at the Eleusinion.

$15^{1}$ On the impact of ritual space on ritual practice: Parkin (1992), Tambiah (1985); also Williamson (2014a).

$15^{2}$ Karlsson (2013 c); Karlsson in Henry et al. (2013), 298-300 and the conference paper Karlsson (2013b). Most of the 80 terracottas found at Labraunda were of the Hellenistic 'Tanagra' and similar types, see Karlsson (2015b). 
Building near Propylon Y - these may well have been connected to the militant character of Zeus Stratios. ${ }^{153}$

Although we know little about Archaic Labraunda, it seems apparent that the ritual changes initiated by the Hekatomnids were focused on the annual festival for Zeus Labraundos. Besides the processions, discussed above, there is evidence of extensive banqueting at the sanctuary which probably took place primarily during the festivals, as well as of athletic contests and games. These would have set the tone for the general nature of the rituals at Labraunda for the Hellenistic period.

\subsubsection{Festivals}

The annual festival, or panegyris, for Zeus Labraundos, was expanded from one to probably five days, and was open to all Karians. ${ }^{154}$ A good deal of the Hekatomnid festivals must have been focused on the rulers and their dynasty. Besides the presumed erection of their statues in the banqueting halls, this is also where they made a public appearance, as we know from an assassination attempt on Maussollos that took place during the annual festival in 355/4 BC..$^{155}$

The ceramics at Labraunda consist largely of tableware and lamps and give an indication of the way in which the sanctuary was used. ${ }^{156}$ The Late Classical period saw a few pieces of Attic red-figured ware, but much more common were the black-glazed plates and bowls, often with impressed palmettes, and mostly Attic in origin. ${ }^{157}$ Attic black-glazed ware drops off in the

153 Hellström (2019). He draws the arrowheads and spearheads in connection with the militant character of Zeus Stratios (Hdt. 5.119.1-2 and Strabo 14.2.23), and the structure called 'Terrace House I' where several of arrowheads were found. I have omitted this Archaic structure from discussion until it is further investigated and published. Säflund believed that the mudbrick structure was an altar, Säflund (1956), 3, although Hellström (2019) argues that it was more likely the base for a statue of Zeus.

154 The festival is called the panegyris in I.Mylasa 3 , line 5; see Hellström (2011a), 149-150. The festival is further mentioned in I.Labraunda 54 with a list of what the events day by day unfortunately this is too fragmented to be of any use here, although Crampa understands it to include five days altogether (p. 85). The incomplete lists of names in I.Labraunda 53-54 and 67 are interpreted as envoys to the festival. I.Labraunda $53-54$ are furthermore imperial copies of a festival decree from the fourth century BC, inviting all Karians to participate in the festival, although the lists of names at the sanctuary imply that most derived from Mylasa - see below on the scope of the sanctuary.

155 I.Mylasa 3 . This attempt on Maussollos's life was the third assault on the satraps: I.Mylasa 1 mentions a plot against Maussollos that had been found out (367/6 BC), and I.Mylasa 2 a statue of Hekatomnos had been vandalized ( $361 / 0$ BC).

156 Hellström (1965).

157 Hellström (1965), 11-15 presents the Attic red-figured and black-glazed pottery; the Panathenaic amphora, on p. 7-11, is discussed below under Games. The objective of the 
Hellenistic period, apparently replaced with local products, especially the fish plates, "poor products with a thin, mat glaze."158 Fine pottery and lamps in the Hellenistic period is rare and this was initially interpreted as a sign of reduced interest. Yet the many mould-made bowls and lamps show that activity at the sanctuary certainly continued, perhaps on a different scale or with a different ritual use. ${ }^{159}$ Unguentaria, small oblong flasks or bottles probably intended to carry precious fluid, were common at Labraunda in the Hellenistic period, and may indicate a specific votive ritual. ${ }^{160}$

The apex of cult ritual is typically the sacrifice, and this surely took place on the temple terrace. Assuming the square structure before the temple is in fact the altar, then this would have served a number of purposes. In the first place, it would have provided the cult image of Zeus with an interrupted view of the sacrifices performed. In the second place, it would have allowed ample space for quite a gathering on the temple terrace, space that would become more and more consumed with honorific monuments, particularly along the northern side. Finally, it would have been directly visible to those entering from Propylon Y, and at the same time its proximity to the edge of the temple terrace would have made the fire and smoke columns visible to those on lower terraces, at least until the construction of Building M in the Hellenistic period.

\subsubsection{Banqueting}

As discussed above, banqueting facilities were the central component of the new architectural complex at Labraunda, ensuring that some 150 or more people could dine in symposium simultaneously; many more (e.g. women and children?) were probably served outdoors in the open or under temporary shelters. ${ }^{161}$ Although we do not know where the food was prepared, the quanti-

volume, as stated in the introduction on p. 2, was to present a general typology of the material from the sanctuary; it was not meant to be a comprehensive catalog, and quantitative analyses were not performed, precluding further interpretations regarding frequency of types.

158 Hellström (1965), 13, drawing a parallel to the lack of building activity in the Hellenistic period; see now Hellström (2009), in which he sees Hellenistic Labraunda as a 'memory theater', discussed below.

159 Hellström (1965), 19-23 for the so-called 'Megarian' bowls, and 49-54 for the lamps. A variety of reasons may account for the change in pottery type, e.g. the shift in focus to Mylasa, a change in the length of festival days, or a wider change in Mylasan economic and trade patterns.

16o Hellström (1965), 23-27. Unguentaria were also found at Lagina, see Chapter 5. On the common appearance of unguentaria in tombs, Anderson-Stojanović (1987).

161 Hellström (2011a), 153-154. The two andrones had floor space for 19 or 20 klinai each, and the six rooms of the East Stoa could each hold 11 klinai, see Hellström 2007, 97-99, 
ties of tableware - both local fabrics and fine Attic black-glazed - unearthed during the excavations certainly testify to widespread formal dining. ${ }^{162}$

Although feasting and sacrificial consumption had no doubt already been a part of the cult at Labraunda, under the Hekatomnids this took on an entirely new dimension. Ritual dining was now directly an extension of ruler representation, combined with divine presence. Anne Marie Carstens and others have suggested that the andrones were used as royal reception halls where political meetings were held, and that with the royal andrones the complex at Labraunda took on the role of an Achaemenid-style garden palace, where they could dine 'in paradise.' ${ }^{163}$ An andron building was dedicated in Halikarnassos to Zeus Akraios, known only from an inscription, and is suggested to have belonged to the Zephyrion palace-temple complex. ${ }^{164}$ Banqueting clearly made up an important part of Hekatomnid ideology, as the dynastic symposiast on the relief of the sarcophagus in the tomb at Uzunyuva shows. ${ }^{165}$ Besides demonstrating the importance of the Totenmahl motif among the Hekatomnids, as Pedersen argues, the Uzunyuva relief also presents us with an impression of their intended reception at real dining functions, as in Halikarnassos and Labraunda, where they surely occupied the central position in the staged arrangement.

The inclusion of formal dining facilities was certainly pivotal to the new Hekatomnid design of Labraunda, and Pontus Hellström observed that "the different levels of dining facilities ... made hierarchical separation of different status groups possible."166 Especially in the andrones, he sees a directional pattern in the arrangement of the klinai, or couches, in the axial space of the royal

Hellström 1989 and Hellström 1996a; Hellström 2007, 23-25 further calculates that each kline could hold 2 diners. The area before the East Stoa was excavated in 1988-1991 and a ceramic study, in 2006, shows that the pottery is mostly tableware, reinforcing the interpretation of dining rooms. Facilities for food preparation have not yet been identified; see Karlsson et al. (2008).

162 Hellström (1971); also indicated in the area near the East Stoa, studied by Lovisa Strand, Karlsson (2008), 109 n. 1, and under excavation at the time of this writing (reports appear in Anatolia Antiqua).

163 Carstens (2009), 88 on "dining in paradise", 86-91; also Karlsson (2015a). Hellström (1989a) suggested that andrones were constructed for meetings of the Karian and Chrysaoric federations and argues for their royal use in Hellström (1996a). Their use for the Karian League finds further support in Carstens (2009), 100 and (2011), 124-130.

164 Isager and Pedersen (2014). The significance of banqueting in civic and royal contexts is further addressed in Strootman (2018).

165 The banqueting scene on the sarcophagus at Uzunyuva is briefly discussed in Konuk (2013), 111 and more at length in Pedersen (2017), 241 and 242, Fig. 22.4, in the context of the Totenmahl and its implications for the Maussolleion in Halikarnassos.

166 Hellström (2011a), 153. 
andrones that would follow the rank of the individual diners. Dining in the andron was already quite prestigious in itself, with plastered walls and mosaic floors. ${ }^{167}$ A different, yet also formal mode of dining was provided in the East Stoa, which was non-axial, and thus more egalitarian and Greek. ${ }^{168}$ In this way, ritual dining combined with these different kinds of formal spaces could easily be used to distinguish visitors at the sanctuary. This could have been critical if the Achaemenid appointment of Hekatomnos, a member of the local elite, to rule as satrap over his peers was indeed perceived as "a shock to the Karian elite," as Hellström postulates. ${ }^{169}$ Including them in the splendor at the sanctuary would have been one of the surest ways of gaining their support - this is another argument to see Hekatomnos as the mastermind behind the transformation of Labraunda, later carried to fruition by his sons Maussollos and Idrieus. ${ }^{170}$

This arena of power negotiation through ritual dining was a legacy the Hekatomnids left to Labraunda and may well have been one of the strongest selling points of the cult place. It is highly conceivable that administrators of Hellenistic Mylasa used this sanctuary to bestow privileges on the local elite or distinguished guests; such public activities certainly continued on a large scale as indicated by the addition of the fountain houses and perhaps Building M. The windows of the 'royal' andrones still framed Mylasa, as mentioned above, and this may have been why the final ruling by Philip v, declaring the sanctuary of Zeus Labraundos as ultimately belonging to Mylasa, was inscribed in the anta of Maussollos's andron, close to the view towards Mylasa and the people that enforced the bond between the polis and the sanctuary.

\subsubsection{Games}

Some 200 meters southwest of the sanctuary was a stadion, one of only two in Hellenistic Asia Minor known to be linked to a sanctuary. ${ }^{171}$ The construction of the stadion is consistent with a date in the fourth century, and it is generally taken to be part of the overall Hekatomnid building program at Labraunda;

167 Henry et al. (2018), 288 on the mosaics, vegetal and Hekatomnid in date, of Andron A (A.-M. Guimier-Sorbets) and 293 on the plaster and wall decoration of the same structure (A. Freccero).

168 Hellström (2011a); also in Hellström (1996a), 168.

169 Hellström (2011a), 152. Hornblower considers the possibility of the choice of Hekatomnos as satrap as connected with his religious office of 'King of Karian League', Hornblower (1982), 55-56, 59 .

170 Hellström (2011a), 152-155.

171 Roos (2011), 257; the other stadion is at Didyma, in the precinct of the Apollo sanctuary. 
adding athletic contests to the cult rituals would fit in well with the expansion of the festivals from one to four or five days. ${ }^{172}$

The stadion measures $34 \times 189 \mathrm{~m}$, with space for 12 to 14 runners and a length of $172 \mathrm{~m} .{ }^{173}$ The lack of natural level space near the sanctuary probably led to its curious construction. Built across a hillside, it resembles an elongated raised platform, with a 'tunnel' for drainage a little to the west. Roos had to exercise his imagination to postulate where exactly the spectators may have taken up their positions, since the area immediately around the stadion is more or less level with it. ${ }^{174}$

Unfortunately there are almost no references to the games and events that took place here, but that they continued into the Hellenistic period is clearly indicated by the inscription honoring an individual and admitting him into the clan or syngeneia of Korris, the priest at Labraunda in the second half of the third century вс. ${ }^{175}$ Two privileges bestowed on this individual include a golden crown which he would receive during the games for his virtue and benevolence as well as front-row seats. ${ }^{176}$ As with so many urban theaters and stadia, this shows that this 'arena' of physical excellence at Labraunda was also a place where community virtues were publicly rewarded. ${ }^{177}$ As an inwardfacing circle, the stadion was an excellent coordinating device for engaging the crowd, facilitating mutual eye-contact and fostering a sense of unity and identity, an aspect that surely added to the power of place at Labraunda. ${ }^{178}$

In summary, transforming ritual space impacts the rituals themselves, whether it reflects ritual change or precipitates it. ${ }^{179}$ The spatial climax of the Hekatomnid monumental complex on the temple terrace sharpened the focus on the rituals that took place before the temple, such as the sacrificial ritual. The facilities and abundance of fresh water at Labraunda allowed for a large group to 'camp out' at the sanctuary for a longer period of time as the main festival, the

172 Roos (2011), 265; Hellström (2007), 142-143. Also a fourth-century Panathenaic amphora indicates the importance of the idea of competition in the newly redesigned sanctuary, Hellström (1965), 7-8, discussed below.

173 Roos (2011), 258-263. But this is the platform, the race course would have been smaller as he observes.

174 Roos (2011), 264-265; he discovered a few step-like features cut from the rock on the slope a little to the north that may have been a quarry, but may also have served as stands.

175 I.Labraunda 11 , third quarter of the third century BC. This inscription is discussed in more detail below.

176 I.Labraunda 11 , lines 7-8, 10 .

177 For this phenomenon in the Roman period, see van Nijf (2010).

178 Chwe (2001), 30-33.

179 E.g. Parkin (1992), 18: "Ritual is formulaic spatiality," on the bodily performative aspects of ritual. 
panegyris, was expanded to four or five days. Massive feasting was another structuring ritual performance. The population would have been divided into those who dined in the Achaemenid-like royal banqueting halls, those in the more 'egalitarian' Greek andrones in the East Stoa, and those who took their meals al fresco, or in temporary shelters in the common areas. This would have continued in the Hellenistic era, as well as the competitive games, which served to (re)produce shared values and local identities. ${ }^{180}$ The sanctuary clearly continued in use at this time, testified by the addition of a central stoa and monumental fountains for additional public water. Ritual seems to have continued as well, with the main change being the shift in context from the Hekatomnids to the polis of Mylasa, but also to the community around the priests, who made their own claims to the sanctuary.

\subsection{Legal Administration and Organization of Labraunda}

The administration of a sanctuary and its local organization is a mirror of its relationship with the city to which it belongs. The priesthoods and the status of the community living at the sanctuary or involved in the cult can thus reflect the level of urban, or local, involvement. ${ }^{181}$ Equally important is the control of the economic resources, as the cash flow going in and out of the sanctuary will reflect the degree of autonomy or dependency of the sanctuary on the polis. These aspects - the priesthoods, the organization of the local community, and the financial administration of the sanctuary and its holdings - are clearly illumined as Labraunda became contested space in the third century вс.

\subsubsection{Administration and Priesthoods}

Nearly all of our knowledge of the priesthoods at Labraunda, and what this function entailed in the Hellenistic period, is derived from a special set of documents at Labraunda. Their content shows that the relationship between the priests of Labraunda and the boule and demos of Mylasa was certainly a barometer for the relationship between the polis and the sanctuary, and how complex this was. These documents, inscribed on the walls of the temple and the andrones, were copies of royal correspondence that concerned two separate episodes in the second half of the third century $\mathrm{BC}$, in which the priests of Labraunda were at odds with the Mylasans. ${ }^{182}$ These letters have been the

180 For games and community in Roman Asia Minor, see esp. van Nijf (2010); also van Nijf (2001) and (2002).

181 For a parallel with Klaros in Roman Asia Minor, see Busine (2013).

182 I.Labraunda $1-3$, and 137 , are in content dated to c. 240 BC and contain the correspondence between Seleukos II and his strategos Olympichos, governor at Mylasa, over the first dispute between Korris, priest at Labraunda, and Mylasa (I.Labraunda 2 and $3 \mathrm{~b}$ are 
subject of a great deal of discussion. ${ }^{183}$ For the context of this study, I will summarize the main points of their contents and then focus on what they reveal about the degree of dependency of the sanctuary on Mylasa in the Hellenistic period.

In the first argument, dated to roughly $240 \mathrm{BC}$, Korris, then priest of Labraunda, filed a complaint directly with Seleukos II against Mylasa, saying that the polis had 1) appropriated sacred lands that were under his management by virtue of his ancestral privileges, 2) kept the profit from these lands, and 3) withheld the sacrificial dues which they owed to the priest. ${ }^{184}$ Seleukos took Korris's claims seriously and ordered his resident strategos Olympichos (whom the priest had circumvented in his complaint) to investigate the matter and take appropriate action, instructing him not to allow Mylasa in the meantime to encroach upon anything belonging to the sanctuary and the priest. ${ }^{185}$ Olympichos interviewed both the priest and the officials of the city. ${ }^{186}$ In the presence of the priest, who had claimed that his ancestral privileges had been violated, Mylasa declared that Labraunda was theirs, and that they had

later copies). The second dispute, I.Labraunda $4^{-7}$ is dated to c. 220 BC and involves Antigonos Doson, Philip v, Hekatomnos (then priest at Labraunda), the Chrysaoric League, Mylasa, and Olympichos. The dossier on Olympichos sheds a great deal of insight into the stakeholders at Labraunda with respect to Mylasa, aided by the discoveries of I.Labraunda 134 (Isager and Karlsson (2008); Isager (2011)) and I.Labraunda 137 (Henry and Aubriet (2015); Carless Unwin and Henry (2016)) and Milas Museum Inv.no. 2012/31a (van Bremen (2016)). For more discussions (among many others): Debord (1969) and (2011); Reger (2010); Aubriet (2012).

183 Disputes between priests and cities, as at Labraunda, have been used to argue for the original autonomy of sanctuaries in general in Asia Minor: see especially Dignas (2002a), 68-69, Virgilio (2001), Debord (1969) and Debord (1982), 51-53. Mastrocinque, following Debord, also sees it as symptomatic of the inherent tensions between the Greek polisoriented system and the indigenous hierarchy, centered on sanctuaries and priestly authority; Mastrocinque (1979), 216-218, citing two other disputes between priests and poleis, at Apollonia Salbake and Myndian Telmessos versus Halikarnassos. Debord (2011) brings several nuances to this position, in light of later discoveries, which are discussed below. Isager (1990) sees it more as a clash of political systems, theocratic versus democratic. Reger considers the Labraunda conflict within the wider context of Mylasan expansion, Reger (2010), 51-53; also Reger (2013) who includes the windows of the andrones and the possible effect of the visual relationship with Mylasa on the priests; my thanks to Gary Reger for giving me access to this article.

184 I.Labraunda 1 is a letter from Seleukos to Olympichos, reviewing the complaint and giving him instructions.

185 I.Labraunda 1 . Lines 7-9 contain the restriction on Mylasa, followed by the clause in lines 9-11: 'For we decree that the concessions made [to Korris by virtue of ancestral privileges]

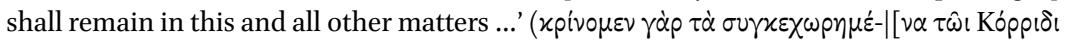

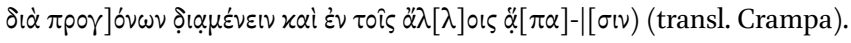

186 I.Labraunda 3. 
been falsely accused by Korris, since they in fact allowed him to administer the sacred lands according to his ancestral rights, and since they had paid him the sacrificial dues as well. Olympichos, who had taken an oath to serve and protect the interests of Mylasa, ${ }^{187}$ ruled in favor of the polis; his decision was apparently endorsed by Seleukos II since his letter to the Mylasans was inscribed on the northwest anta of the temple (Figure 3.6) and no more was heard of the matter. ${ }^{188}$

Some twenty years later, however, a second dispute arose when Hekatomnos, priest of Labraunda at that time, made an appeal to Philip v of Macedon, who succeeded Antigonos Doson and occupied the area around 220 BC. ${ }^{189}$ Philip responded by addressing the people of Mylasa, ${ }^{190}$ informing them that Hekatomnos had presented him with a letter written by Philip's father, i.e. Antigonos Doson, to the Chrysaoric League ${ }^{191}$ in which Antigonos Doson had agreed that the priesthood and the sacred lands would belong to Hekatomnos,

187 I.Labraunda 3 and 137. Olympichos referred to the oath that he copied for the people of Mylasa, in which he had vowed to 'assist the Mylasans, at they requested, in preserving what belonged to them in the country, both the [sacred things] in the shrine of Zeus Labraundos and all the other things, and also the land in the neighborhood of Labraunda and the other land which was [theirs] and all the other items which had been granted to

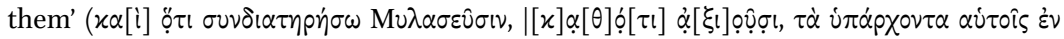

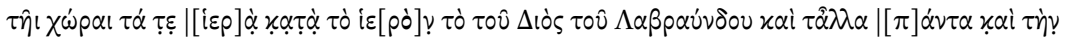

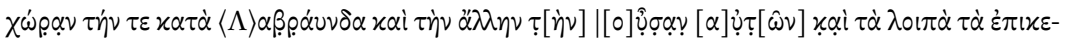
$\chi \omega \rho \eta \mu \varepsilon \dot{\varepsilon} \alpha \pi \dot{\alpha} v \tau \alpha$ ), in I.Labraunda 3 , lines 10-14 (transl. Crampa). Later, he declares that he would adhere to his oath and continue to 'try to assist you [i.e. the Mylasans] in preserv-

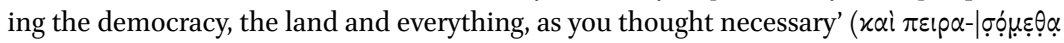

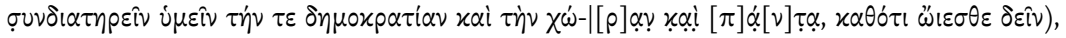
lines 29-31 (transl. Crampa). The oath and its implications are discussed in Henry and Aubriet (2015) and Carless Unwin and Henry (2016) in connection with I.Labraunda 137.

188 Since it had already been decided that Labraunda would belong to Mylasa at Seleukos's liberation of Mylasa, Crampa believes that "... the king and Olympichus seem to have rather lazily settled the case, whatever its details, in the city's favor," in I.Labraunda p. 85. Yet it is clear that Seleukos gave weight to the priest's complaints. Virgilio considers the reliance of kings on cities, and observes that in cases of resistance to civic authority, they tend to favor the cities as a rule, Virgilio (2001). Pontus Hellström observed that if the date of 240 BC is correct, then Seleukos II was in Syria while Hierax was gaining ground, making it extra vital to ensure the support of local cities (pers. comm. 27.03.2011).

189 This dispute is contained in I.Labraunda 4 and $5^{-7}$, dated to the period when Philip v was in Mylasa, c. 220 BC.

190 I.Labraunda 5.

191 The Chrysaoric League, a Karian-wide federation that was strong in the third and second centuries and had connections with the Ptolemies. Although they later settled near Stratonikeia, the first reference to the League is at Labraunda, I.Labraunda 43, dated to 10 June, 267 BC, in which a Ptolemaic official, Apollonios, son of Diodotos, is honored at Labraunda by the League for being an incorruptible and blameless judge and passing fair 
according to his ancestral rights, and that he, Philip, did not believe a word of it. This argument recalls the previous dispute over the administration of the sacred lands belonging to Zeus Labraundos, except that by this time it is clear that all of the revenues from the land, whether through the priest or through those who leased it, were collected by the city who then reinvested it, presumably channeled through a sacred funds, back into the festivals and sacrifices at Labraunda. The Mylasans further emphasize that everyone residing in the sanctuary is in fact a citizen of Mylasa. Finally, they reminded Philip that Seleukos II, when he granted Mylasa its freedom, also granted them Labraunda since they 'possessed it from the beginning.' ${ }^{192}$ Their need to stress this point implies on the one hand the opposite case, that they did not really control the shrine; despite the many interfaces between Labraunda and Mylasa there is little proof prior to the mid-third century вС that would substantiate their claims. ${ }^{193}$ On the other hand, the Hekatomnid promotion of the sanctuary should also be seen in context with their wider investment in the security of the regions surrounding the plain of Mylasa, as Descat and Reger have argued for the access routes from the south and west, respectively. ${ }^{194}$ Surely the chain of fortifications lining the sacred road to Labraunda reiterate this wider concern. In this vein, Mylasa would have naturally considered Labraunda as vital to the polis and therefore belonging to it.

Whereas Korris's dispute with Mylasa primarily concerned his own position, the ancestral claims of the later priest Hekatomnos were obviously interpreted as a much more serious threat to Mylasan control over the sanctuary. Philip v clearly felt that Hekatomnos and the Chrysaoric League were trying to manipulate him into delivering Labraunda to them. Wary of Olympichos as well, he personally investigated the matter (probably under the guidance of Mylasan envoys) and evidently saw and read the documents inscribed at the sanctuary from the ruling of twenty years before. Basing his decision on that, he

sentences. This inscription shows that the Chrysaoreis met at Labraunda in the early third century and clearly used it as their own public platform.

192 I.Labraunda 5 , lines 22-36; the rest of this inscription concerns Seleukos's strategos Olympichos.

193 See, for example, the inscription $S E G 591503$ (Gauthier (1999)), an honorific decree for judges from Kolophon for restoring the 'ancestral laws' of Mylasa, which states in line 24

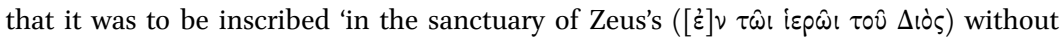
designating which Zeus. The editor takes this lack of epithet as an indication that Mylasa did not yet possess Labraunda, since it otherwise always distinguished between Zeus Labraundos or Zeus Osogollis; the inscription is then presumed to belong to the early third century, when the area was under Ptolemaic control (as shown in I.Labraunda 43).

194 Descat (2013) on the acquisition of the strategic access route near Sekköy which he identifies as Talagreia; Reger (2010) on the 'Little Sea' near Iasos. 
judged in favor of Mylasa. Philip's review of prior disputes between Mylasa and Labraunda neatly shows how inscriptions could affect a later generation. ${ }^{195}$ They also show how the Macedonian commander upheld a decision made by his Seleukid predecessor, perhaps to curry favor with Mylasa and ensure continuity and stability in the area. The general content of this dossier and the fact that it was all recorded at the sanctuary made it clear to everyone that Labraunda, still an impressive place worth fighting for more than a century after the Hekatomnids, ultimately belonged to Mylasa.

Hekatomnos's actions thus evoked the opposite response of what he had intended, since Philip v determined 'that the shrine belonged neither to the Chrysaoreis nor to the other Karians but was yours [i.e. the Mylasans], and also voted to [exclude] the Chrysaoreis [from the shrine] as they desired to appropriate it for themselves.' ${ }^{196}$ He further evicted the Chrysaoric League, renounced the priest for telling lies, and ordered Olympichos to evacuate the stronghold 'Petra', probably the Akropolis Fortress above the sanctuary. ${ }^{197}$ Olympichos appears to have had his own agenda with Labraunda, perhaps supported by Mylasa. The other letters pertaining to this episode, I.Labraunda 6 and 7, as well as I.Labraunda 4, concern Olympichos's evacuation of the area and final transfer of control over Labraunda to Mylasa. ${ }^{198}$

In this last dispute, therefore, the controversial matter of control over the sanctuary was apparently settled once and for all. Inscribing these rulings at the sanctuary itself was obviously the best way of ultimately establishing Mylasa's possession of Labraunda and broadcasting this for all to see - for the surrounding communities who visited the sanctuary, the Mylasans themselves who worshiped there, but also for the priests who lived there. One cannot help

195 Idrieus's use of the ethnic Mylaseus in his architrave inscriptions (on Andron A, I.Labraunda 15; the Temple, I.Labraunda 16; the 'Oikoi', I.Labraunda 17; the South Propylon, I.Labraunda 18; and perhaps the 'Doric Building', I.Labraunda 19, though this may be later, see below) surely galvanized the link between the polis and Labraunda for the following generations.

196 I.Labraunda 5 , lines 14-18, transl. Crampa.

197 On 'Petra', Henry and Aubriet (2015), 686-691.

198 These letters are published by Crampa in the order in which they appeared on the south anta of Maussollos andron (Andron B), from top to bottom; I.Labraunda 4 was inscribed on the north anta of Idrieus's andron (Andron A), see Figure 3.6 and Crampa in I.Labraunda in vol. 1 p. 22, 27-28 and vol. 2 p. 221. I.Labraunda 7 is the letter from Philip to Olympichos, ordering him to transfer the shrine, the land and everything else back to Mylasa, while I.Labraunda 4 and 6 are letters from Olympichos to Mylasa, stating his intention to restore everything back to the Mylasans while defending his actions as having been at their request and on their behalf. Also Hedlund (2014), van Bremen (2016). On Olympichos, see e.g. Savalli-Lestrade (2001), 281-283; Virgilio (2003), 170-184; Aubriet (2012) and Henry and Aubriet (2015). 
but wonder if it was an exercise in humility for them to observe how the correspondence in which they were made out as liars was carved first into the sides of the temple walls, just across from the 'Oikoi', their administrative structures, and then later in Maussollos's andron, still one of the most prestigious structures on the premises (Areas C and D on Figure 3.6).

This brings us, finally, to the question of the nature of the priesthood at Labraunda. These letters certainly display a considerable degree of at least perceived autonomy on the part of both Korris and Hekatomnos, who if they really were under the jurisdiction of the polis, would have been circumventing both the legal structure of Mylasa as well as the position of Olympichos in directly addressing the ruler. ${ }^{199}$ An inscription discovered in Iasos that mentions the benefactions of Hekatomnos, son of Korris, and priest of Zeus Labraundos, introduces a new perspective on the subject. ${ }^{200}$ This is an honorific inscription for Hekatomnos, in which he is given a golden crown of maximum weight for his virtue and benevolence towards the city (of Iasos) and with respect to his ancestors ( $\pi$ pórovol). Gianfranco Maddoli, who published the inscription, establishes the hereditary priesthood at Labraunda in the Hellenistic period, and thus the lineage of the priests themselves, drawing a connection back to the dynasty of the Hekatomnids, although the direct link is unknown. ${ }^{201}$ That the Hekatomnids were personally involved in the cult is beyond doubt (e.g. the ample appearance of the god on their coinage), but this could also shed new light on evidence such as the Tegean relief which shows Idrieus and Ada worshiping Zeus Labraundos. ${ }^{202}$ In the opposite chronological direction, however, Maddoli is able to map the lineage of the priests of Zeus Labraundos, starting with Korris in the mid-third century, through Hekatomnos and on down to the beginning of the first century вс. ${ }^{203}$

Maddoli's hypothesis provides a new angle for interpreting Hellenistic Labraunda and the position of its priests, giving Pierre Debord cause to reexamine the situation. ${ }^{204} \mathrm{He}$ underscores the intimate relationship between

199 Although the point of Dignas (2002a) is that kings were regularly mediators between cities and sanctuaries; her position however has been criticized by Corsten and Debord: Corsten (2006); Debord (2011), 135 .

200 Maddoli (2007), 306-316 no. 2oB.

201 Maddoli (2007) and (2010), 128-129. Debord also presumed some kind of link, Debord (1982), 33 ० n. 5 .

202 Now in the British Museum, see below.

203 Maddoli (2007), 316, with references. This complements Crampa's previous attempts in I.Labraunda, p. 200.

204 Debord (2011), analyzing the situation from the point of the different actors involved in the conflict: the priests, the city, the king, the Chrysaoric League, and Olympichos. He also views the Iasian honorific decree of the Labraundan priest in the context of a dispute 
the Hekatomnids, who resided in Mylasa, and Labraunda, evidenced by the iconography of the god on their coinage, and of course their heavy monumentalization of the sanctuary. Their strong personal ties with Labraunda would especially make sense if the priesthood were directly linked to the dynasty, for example through a side branch of the family. ${ }^{205}$ Following this, it would only be logical if an offshoot of the dynasty would continue to promote their status, even after the passing of the Hekatomnids. Debord explains this in part by emphasizing the polis as the new organizing element in the political grid in the Hellenistic world:

Elle est toute la partie occidentale de l'Anatolie le relais naturel du pouvoir royal, qu'il s'agisse d'une cité grecque ou de modèle grec comme Mylasa. Cette dernière entend bien recuperer au moins dans son propre environnement tout l'heritage hecatomnide et presente a cet effet de solides arguments concrets. Par conséquent tout finit par rentrer dans l'ordre, c'est-à-dire que le sanctuaire est absorbé définitivement par Mylasa. ${ }^{206}$

In this context, the underlying fabric of the dispute between the priests and the polis could be interpreted as a question of who the legitimate heirs were of the Hekatomnid legacy - of course the priests tried to capitalize on their own heritage and 'ancestral privileges', but it was not an even game since the city ultimately had the power and especially a legal and institutional system that was universally recognized.

It seems then that we are dealing with a critical difference of perception as to what exactly was negotiated between the city and the priests in the terms of the 'freedom' supplied to Mylasa by Seleukos II and enforced by Olympichos, in which the administration of Labraunda was transferred to the polis. The Mylasans obviously understood that they would ultimately be responsible for the administration of the sanctuary and its holdings; as Debord argues, they were probably primarily interested in streamlining the administration of

which Iasos had with Mylasa who encroached upon their area, and that the Iasians were probably eager to support anything that might potentially weaken the Mylasans, Debord (2011), 137-138. The dispute of 'The Little Sea' is discussed in more detail in Reger (2010), 44-49.

205 Debord (2011), 143. Hellström (2011a), 152 observes that the Persian appointment of the Hekatomnids as satraps "not only against normal Persian practice. It was probably also a shock to the Karian elite." Their close relationship, possibly as priests, with Karian-centered Labraunda may have been one of the reasons for their appointment.

206 Debord (2011), 144. 
Labraunda to follow that of their other polis sanctuaries. ${ }^{207}$ At the same time, however, they also wished to respect the position of the residing priests and so Mylasa agreed that the priests would retain certain tasks, yet be accountable to the polis. The priests on the other hand apparently interpreted this more as a construction of final - and separate - responsibilities, especially pertaining to the sacred lands and their proceeds. ${ }^{208}$ Although they themselves were apparently considered as citizens of Mylasa, it must have been difficult for Korris and his son Hekatomnos to make the transition from dynastic priesthood to civic magistrate (perhaps particularly with regard to the sanctuary's treasury), which was the normal role (and elective office) for the priests of most urban cults in the Greek polis. ${ }^{209}$ The compromises which were obviously made, such as respecting their 'ancestral privileges', must have left enough room for vagaries that eventually led to conflicting views, which escalated to the level of the ruler. Although many of the details in the matter will remain speculative, Debord is right to argue that against the backdrop of the Hekatomnids, the case of Labraunda versus Mylasa is unique and therefore cannot be lumped together with other examples of clashes between 'indigenous' priests and Greek cities as a general sign of inherent tensions between native authority and the Greek model of polis administration. ${ }^{210}$

Nonetheless, as Debord points out, the priesthood at Labraunda hardly suffered from this event. ${ }^{211}$ The clan, or syngeneia, of Korris was already strong enough to model itself on the polis, extending decrees of proxeny to new members, granting them citizenship, giving them tracts of land, honoring them with a golden crown, or a front seat at the games, allowing them to participate in whatever belonged to Korris and his kin, and inscribing this decision in the sanctuary. ${ }^{212}$ By the second and early first century BC, a number of the family members are seen in leading positions among the Mylasan elite, taking their

207 Debord (2011), 138-139.

208 Debord in fact sees Korris as wanting to be the master of his own domain, using religious authority to achieve secular ambitions, Debord (2011), 137.

209 E.g. Bruit Zaidman and Schmitt Pantel (1992), 49-5o, noting however some prominent exceptions such as the priesthoods of Athena Polias and Poseidon Erechtheus in Athens which were for life and restricted to a particular family.

210 Two other known examples include that of the Apollonia Salbake, established as a garrison and eventually taking control of the neighboring sacred villages, much to the dismay of the local priests (Robert and Robert (1954), 285, no. 166), and Myndian Telmessos against Halikarnassos (Debord (1982), 51-53; Mastrocinque (1979), 216).

211 Debord (2011).

212 I.Labraunda 11-12; Labraunda thus also served as a public podium for this priestly syngeneia, through the blurring of personal and urban space. See also the next chapter for parallels. 
place in the boule, acting as urban benefactors, and even being involved in land management. ${ }^{213}$

How long was the priesthood at Labraunda occupied by Korris's family? Maddoli was able to trace the lineage down to a third Korris in the early first century BC. ${ }^{214}$ In the later first century BC, Strabo remarks how at Labraunda 'the priestly offices are held by the most distinguished of the citizens, always for life', rather than being an annually held office. ${ }^{215}$ Yet we have no indications that the priests at this time were related to each other. Also, in the later first century $\mathrm{BC}$ or early first century $\mathrm{AD}$, we know of a certain Mylasan named Pollis who was listed as successively being the annual civic magistrate (stephanephoros), priest of Zeus Osogollis (in town) and priest of Zeus Labraundos, as well as market official (agoranomos) ${ }^{216}$ Laumonier therefore believes that Strabo is recalling the older situation, whereas under the pax romana the polis and religious organization of the sanctuaries underwent an extensive reorganization. ${ }^{217}$ By this time priesthoods were annually elected, and were in any event not based on family ties. ${ }^{218}$

Another religious administrative office exercised in the Hellenistic period was that of neokoros. This position appears in the later third century $\mathrm{BC}$, in a letter in which the priest and the neokoros refuse to repay a loan, probably to the Chrysaoric League. ${ }^{219}$ Dignas emphasizes how the neokoros took a stand, together with the priest, showing the authority of this position in the financial

213 Debord (2011), 144 mentions: Ouliades, son of Hekatomnos, son of Korris, grants a large tract of land, worth 7000 drx to the sanctuary of Apollo and Artemis at Olymos at the turn of the second to first centuries BC (I.Mylasa 864); Hekatomnos, son of Ouliades, who was apparently foremost in a list of contributors to a stoa, with a very high sum of $200 \mathrm{drx}$. (I.Mylasa 5o1, line 3 (Blümel et al. (2014) no. 21)) is also involved as priest of Labraundos in the land leases of Olymos (e.g. I.Mylasa 814 (Blümel et al. (2014) no. 43), 816B-D, 848); in the first century вС, a Hekatomnos, priest of Zeus Labraundos, dedicates a statue of the priest of Zeus Osogollis to Zeus (I.Mylasa 406); also Korris, son of Hekatomnos, priest of Zeus Labraundos, was secretary in the boule (I.Mylasa 102, lines 2-3).

214 Maddoli (2007), 316.

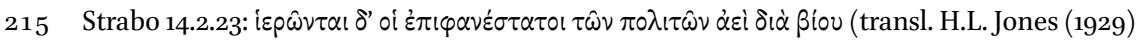
The geography of Strabo, LCL 223).

216 I.Mylasa 326 is an honorific decree for Pollis for dedicating eight columns to the sanctuary of Zeus Osogollis; see also Laumonier (1958), 58.

217 Laumonier (1958), 111.

218 I.Labraunda 59 and 6o indicated annually elected priesthoods at Labraunda in the second century AD, discussed also on p. 201.

219 I.Labraunda 45, line 6 mentions the priest and the neokoros together. The letter misses the first and last lines, but Crampa infers the Chrysaoric League as addressee due to the refer-

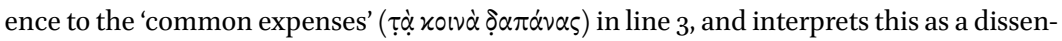
sion between the League and the priest at Labraunda (probably for membership in the League), who this time was supported by Mylasa as the polis now controlled the sacred 
administration of the sanctuary. ${ }^{220}$ Rostovtzeff had already observed how the role of the neokoros carried considerable weight regarding the financial affairs at sanctuaries, even gaining in importance by the imperial period. ${ }^{221}$ This seems to be the case at Labraunda, where two imperial decrees emphasize the final responsibility of the neokoros for the proper administration and management of the sanctuary, showing this to be both an appointed office and a highly distinguished title which one carried even when no longer in office. ${ }^{222}$ Labraunda had by this time thus become fully institutionalized according to the current urban model of sanctuary administration.

\subsubsection{Community and the Syngeneia of Korris}

In their plea to Philip $v$, the Mylasans stressed that everyone residing in the

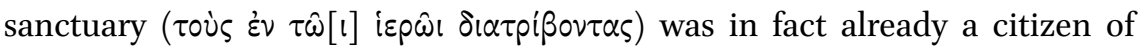
Mylasa and was divided among their tribes and subject to the same laws. ${ }^{23}$ We know that there was a community called the syngeneia of Korris, ${ }^{224}$ and that it was large enough to be subdivided into tribes, since the honorand in I.Labraunda 11 is assigned to the tribe of Ibanollis. ${ }^{225}$ Olympichos, after the second dispute, refers to Korris's kinship-based group as a patra rather than

funds; the letter was probably written by Olympichos, see I.Labraunda vol. 2 p. $5^{8-59}$; also van Bremen (2017).

220 Dignas (2002a), 209.

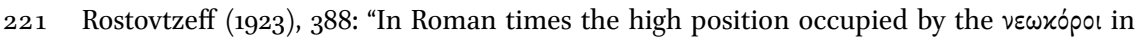
Asia Minor, e.g. in Smyrna and in Aezani, may have been an heritage from the Hellenistic period. I cannot help thinking that the Hellenistic vewxópor gradually replaced the native high priests, especially in the management of the temple finances and the temple estates," cited in Crampa, I.Labraunda vol. 2 p. 121, in connection with no. 6 o.

222 Neokoroi are attested in I.Labraunda 59 and 6o. I.Labraunda 6o restricts the access of those allowed to speak to the priest to '[those who have already been priests] of Zeus Labraundos, their servants, the one who has been elected or has undertaken to be the priest of this god in the following year, his neocoroi, both the appointed ones and those who have already held the office, or the god's public servants, when they do not serve the doorkeeper' (transl. Crampa, vol. 2 p. 120), followed by penalties for violating this. See also Dignas (2002a), 209-210.

223 I.Labraunda 5 , lines 31-33.

224 I.Labraunda 11-12. Syngeneiai, or 'kinship groups', were common in Karia and used to denote any kind of community based on a real, perceived or desired familial relationship, e.g. Korris admitted outside (non-relative) members to his syngeneia, as discussed above. On this syngeneia, see especially Bresson and Debord (1985), 205-206. The position of syngeneiai between cities and communities is discussed in more detail below, particularly in the case studies of Sinuri and Panamara.

225 I.Labraunda 11, line 11. On the significance of the name Ibanollis, see Debord (2011), 137. 
a syngeneia. ${ }^{226}$ Bresson and Debord take this as a sign that Labraunda had already been absorbed by Mylasa by the time of Olympichos's letter, and that the syngeneia had become a "simple patra" of Mylasa. ${ }^{227}$ Yet since these terms do not always appear to be strictly defined, ${ }^{228}$ it seems hazardous to date the absorption of Labraunda by Mylasa using only this single reference.

At Labraunda, some remains of settlement activity have been found west of the temenos and north of the stadion, in the area of the excavation house. Several tombs have been discovered near Labraunda. The most prominent is certainly the Built Tomb that crowns the site, just north of the temenos and near the split rock. An altar was discovered in the open area before the tomb and the ensemble now seems to date from the early Hekatomnid era; it may well belong to members of the dynastic family. ${ }^{229}$ If this is the case, then it would lend additional support for the interpretation of Labraunda as a royal center, with the monumental burial of the dynasts served to mark their presence for all time. Most of the tombs in the area, however, are much more modest, consisting primarily of rectangular trenches cut from the bedrock and covered with a stone gabled lid; whether these were the tombs of pilgrims or the residents of the settlement near the sanctuary is unknown. Over 120 of such tombs, ranging from Late Classical to Late Roman, were discovered along the sacred road within two kilometers of Labraunda. ${ }^{230}$ Tombs near sanctuaries may be more common than once thought - see the other case studies in this volume - yet this number speaks for a large community of either local residents or devoted pilgrims. North and east of the stadion rock-cut foundations were found for two houses, "presumably contemporaneous with the shrine,"

226 I.Labraunda 4, line 6. The term patra is largely restored by Crampa by analogy with the sympoliteia between Olymos and Labraunda, and in Mylasan decrees, e.g. I.Mylasa 863, which shows the division of Olymos and Labraunda into demes, syngeneia and patrai; see Crampa's commentary on line 6 in I.Labraunda, p. 25. In his discussion of the sympoliteia between Olymos and Mylasa, Reger (2004), 164-168, observes that the phyle of Olymos is referred to as syngeneia after the treaty; grants of citizenship, however, continue.

227 Bresson and Debord (1985), 206.

228 See also Jones (1987), 320, on the simultaneous usage of syngeneia and patra in late third century Mylasa.

229 Henry (2014), Henry et al. (2016), 41-416, and Henry (2017), 566-568, pushing this date earlier than suggested in Hellström (2007), 135-137, who considered the priest Korres as a potential occupant. Olivier Henry is more cautious in identifying the occupants of the tomb, but does not exclude early members of the Hekatomnid dynasty. The earlier date is equally interesting in connection with the development of the barrel vault, traditionally considered a Macedonian invention, Boyd (1978). The Built Tomb at Labraunda received a number of reburials in the Hellenistic period, O. Henry in Henry et al. (2013), 301-310 and in Henry et al. (2014), 292-294.

230 Henry (2017), 565; also O. Henry in Karlsson et al. (2008), 116-121. 
as well as a press for wine or oil.231 The area around the sanctuary has been subjected to systematic surveys by Axel Frejman, who has found evidence for a more extensive settlement, including a farmstead below Labraunda, within a larger road network that clearly situates the site within the wider social and economic landscape. ${ }^{232}$

While it may be assumed that Korris's syngeneia occupied the settlement near Labraunda, but in urban contexts syngeneia were not always bound to a specific locality. The Pormounos that centered on Sinuri seems to have been a dispersed collective. At Mylasa, the three main tribes of old, the Otorkondeis, the Hyarbesytai, and the Konodorkondeis, were further subdivided into syngeneiai. Hekatomnos, son of Ouliades, was a member of the Maunnites syngeneia, which had become a subdivision of the Otorkondeis phyle. ${ }^{233}$ Yet he was also priest of Labraunda, and as such would no doubt have been a member of the syngeneia, or patra, of Korris, assuming that it was still functional at that time. Whether he actually lived at the settlement in Labraunda, commuted from Mylasa, or both, is unknown.

Many questions remain regarding both the settlement and the syngeneia or patra remain to be answered. For example, although Labraunda already belonged to Mylasa and its residents were full citizens of the polis by the time of I.Labraunda 5 in the later third century, nonetheless a re-division of both Olymos and Labraunda took place at some point after the sympoliteia with Olymos. ${ }^{234}$ Both communities are enrolled into the phylai, syngeneia, and patrai of Mylasa; for Olymos this could be a logical consequence of the sympoliteia, but if the 'citizens' living at Labraunda were already Mylasans then it is unclear why they would need to be enrolled again in these municipal divisions; Labraunda was probably not yet fully incorporated into Mylasa at this point.

231 Hellström (1990), 248-249. I am indebted to Pontus Hellström, who graciously sent offprints of these early KST reports when I could not access them otherwise.

232 Frejman (2020), 23-127 on Labraunda; see A. Frejman in: Henry et al. (2015), 310-314; Henry et al. (2016), 357-364; Henry et al. (2017), 201-204; Henry et al. (2018), 262-267. Also Frejman (in preparation).

233 This could be one explanation of his generous contribution towards building a stoa that no doubt belonged to the Otorkondeis, I.Mylasa $5 \mathrm{Ol}$ (second or first century BC) since all of the contributors were from either the Maunnites or Tarkondareus syngeneiai. On the Maunnites and Tarkondoreus as subdivisions of the Otorkondeis, see Laumonier (1958), 58, and Bresson and Debord (1985), 208-209.

234 I.Mylasa 861, 863. Laumonier (1958), $40 \mathrm{n}$. 5 sees the residents at Labraunda as an independent community on equal footing with Olymos, i.e. as syngeneia, after its absorption which was once thought to be in the mid-first century вс, but see Reger (2004), 164-168 on the sympoliteia. Laumonier (1958), 40 n. 9 refers to the ethnics 'Labrandenus' and 'Labrandios' in the same inscription. 


\subsubsection{Economic Resources}

Labraunda's sacred lands were a viable source of income and were at the center of the initial conflict between the priests and the polis in the third century BC, discussed above. Olympichos seems to have initiated a construction of land-lease in the area around Mylasa when he donated property that he had purchased from Queen Laodike to Mylasa via the sanctuary of Zeus Osogollis. ${ }^{235}$ The inscription calls for a hereditary lease at an annual rent of five percent, with the proceeds going towards the festivals of Zeus, presumably Zeus Osogollis. The inscription was to be displayed at that sanctuary, but also in the sanctuary of Zeus Labraundos, 'in the most conspicuous place'. ${ }^{236}$ The list ends with a description of the properties, including lands sacred to 'Zeus Osogoa Allolios' and 'Ys Sinuri', although apparently none belonging to Zeus Labraundos. ${ }^{237}$ Labraunda had clearly acquired the role of urban podium by that time.

Lands belonging to Labraunda are mentioned in some of the decrees from Olymos, just west of Labraunda (Figure 3.1). Olymos initiated a land-lease construction in the later second and first centuries BC for the sanctuary of Apollo and Artemis, and several tracts are described as being adjacent to lands belonging to Zeus Labraundos. ${ }^{238}$ Three more inscriptions at Labraunda pertain to dealings with land. Two are heavily fragmented and are dated to the late second century вс. One concerns the renewal of a land-lease, probably by Mylasa, and presumably concerns lands belonging to Zeus Labraundos although this is not clear. ${ }^{239}$ The other is even more fragmented and just mentions a donation involving trees and probably land. ${ }^{240}$ These are discussed further below in the context of urban mediatization at the sanctuary. Finally, an inscription cut into the face of a rock was discovered near the monumental fountain northwest of the shrine and is suggested as belonging to an estate in the late Hellenistic

235 I.Labraunda 8. The context of such land donations by rulers is interpreted both within the Achaemenid and Macedonian traditions: Briant (2006); Thonemann (2009); Descat (2013); also van Bremen (2016), 16-17, 20-21, on the connection with Queen Laodike.

236 I.Labraunda 8B, lines 24-26, also discussed below under Civic Decrees.

237 I.Labraunda 8C, line 31.

238 E.g. I.Mylasa 8o5, 8o6, 817, 831. See also above for the role of especially Hekatomnos, son of Ouliades and priest of Labraunda, in several land-lease transactions of Olymos. The Mylasan land-lease construction, in which especially the sanctuaries of Zeus Osogollis and Sinuri were also heavily engaged is discussed in more detail in the next chapter.

239 I.Labraunda 5 o.

240 I.Labraunda 90. 
period. ${ }^{241}$ Nearer to Labraunda, the surveys conducted by Axel Frejman, mentioned above, aim to better understand the integration of the sanctuary with its own hinterland in the fertile and well-watered Beşparmak Dağları. Frejman argues for a market function at Labraunda, where local meat and produce could be traded at this central place along the mountain road. ${ }^{242}$

Attempts have been made towards identifying and locating some of the domains listed in the Olympichos dossier as the inscriptions tend to be specific regarding natural features and the owners of bordering property as identifying markers. ${ }^{243}$ Altogether they present an image of a patchwork countryside with a mixture of private and individual sacred plots that could belong to different deities. Exactly how extensive the estates of Zeus Labraundos were, however, is impossible to tell, but it was obviously the primary source of income for the sanctuary, and thus enough to be a bone of contention between the priests and the polis. Controlling the resources of the sanctuary obviously meant controlling the economic vitality of the sanctuary itself. With their long-term history of involvement at the sanctuary, it is only logical to envision Korris and his successors assuming a personal responsibility in the financial affairs of the sanctuary and the management of the sacred lands. This would explain their surprise, and dismay, in realizing that they could now be circumvented by revenues passing directly from the lessees to the polis, even though Mylasa states that the proceeds were reinvested in the sanctuary. ${ }^{244}$ That the priests were included at all in the chain of responsibilities was clearly only by the grace of the polis - in reality they were relieved of their ultimate control of the administration of Labraunda.

In sum, most of the information on the organization of Labraunda dates from the Hellenistic period, thanks to the increase in the 'epigraphic habit' but especially to the lengthy conflict between the polis and the priests as to who controlled the shrine. The dispute appears to hinge on differing interpretations

241 Henry et al. (2014), 272 and Fig. 31. The upper part of the inscription is eroded, but the name AN $\triangle \mathrm{PONIK}$ is preserved, in large letters, $\mathrm{c.} 17-20 \mathrm{~cm}$, and inscribed at a height of $2.15 \mathrm{~m}$ above ground, clearly meant to be seen from afar.

242 The surveys are reported by Frejman in: Henry et al. (2015), 310-314; Henry et al. (2016), 357-364; Henry et al. (2017), 201-204; Henry et al. (2018), 262-267. On location and market function: Frejman (2018); Frejman (2020), 23-127; Frejman (in preparation). Reports on fauna remains from the early imperial period show an emphasis on sheep and goat, I. Stojanovitch in Henry et al. (2018), 282-285.

243 Carless Unwin and Henry (2016), who discuss among others the territory mentioned as Larysynia in I.Labraunda 137. Also Pernin (2014), and the discussions around the property transaction between Mylasa and Kindye, witnessed by delegates from Karian cities in I.Mylasa 11, see Descat (2013); van Bremen (2013); Descat (2014).

244 I.Labraunda $5,23-27$. 
of the stakeholders. As Debord pointed out, the priestly family were connected with the ruling dynasty, probably through a blood tie, and were still running the sanctuary in the early Hellenistic period. ${ }^{245}$ The liberation of Mylasa by Seleukos II in 246 BC, however, included Labraunda and of course its sacred lands, which were considerable and now under Mylasan control. The residing priest would surely have felt this as an infringement of his hereditary rights. A generation later another priest even conspired with the Chrysaoric League to take control of Labraunda. These conflicts and the way in which they were handled clearly show a shrine in transition. The priests obviously had wide latitude, writing to the kings directly and even running their own local community (syngeneia). At the other end, the polis of Mylasa, a mosaic of local entities yet always represented in these texts by the singular demos, ${ }^{246}$ was insistent that Labraunda had always belonged to it, and that the community at the sanctuary was in fact made up of Mylasan citizens. On the surface these conflicts could be interpreted as a cultural miscommunication between the 'indigenous' priests and the institutionalized (i.e. 'Hellenized') polis, or between local versus centralized administration. Yet the Hekatomnid legacy at Labraunda and the underlying question of its legitimate heirs may well have been the heart of the problem. Whoever administered the powerful sanctuary had ultimate control over its ancient and monumental space, its rituals, its vast resources, and its wider appeal. The priests had a vested interest in maintaining control over the sanctuary, and were well-disposed towards the Karian-centered Chrysaoric League in reestablishing the regional impact of the shrine. Mylasa, however, clearly had other plans for Labraunda, where its own population took pride of place. In the end, the polis triumphed, the sanctuary became an urban podium, and a shift took place in the priesthood, which, by the later Hellenistic period, had become an elective and annual office, one of the regular institutions of the polis.

\subsection{Urban Mediatization at Labraunda}

Until now we have examined the spatial, religious, and administrative transformations at Labraunda under the increasing involvement of Mylasa. This section investigates the various ways in which the cult place and its deity came to transmit urban ideology, e.g. through decrees or symbolism. First, it

\footnotetext{
245 Debord (2011), discussed above.

246 Mylasa was a composite body, made up of phylai, syngeneiai and patrai that appear to be more preoccupied with their own community than with that of the polis, this is discussed further in the next chapter. Yet in political situations, such as this at Labraunda, it is the demos of Mylasa who speaks and is addressed as an entity, e.g. I.Labraunda 3 , line 29 and I.Labraunda 5 , lines 1-2, 24.
} 
is important to ascertain the scope of Labraunda's sacred network, i.e. who worshiped Zeus Labraundos, who was the audience at this sanctuary, who was it meant to impress? Following this, the kinds of communications, decrees and documents that represent the city of Mylasa at Labraunda will then be discussed. The last part of this section deals with the opposite process of how the god of Labraunda was represented within the urban sphere, e.g. through his imagery on coinage, or the iconic use of his attributes, especially the double-axe. All of this will be viewed in light of change or consistency with the Hekatomnid period in order to discern the extent to which the polis was retaining the mechanisms of the dynasty while using the sanctuary for their own purposes.

\subsubsection{Scope and Network}

In the first literary mention of Labraunda by Herodotos, quoted at the beginning of this case study, Karians are seen fleeing as a group to the sanctuary of Zeus, pursued by the Persian army. ${ }^{247}$ Although perhaps not the center of the Karian League, Labraunda was nonetheless well-known in Karia by the advent of the Hekatomnids, whose transformations seem to be driven by the idea of promoting the sanctuary as the primary religious center in Karia. Their newly reorganized festival - in which they had a starring role - were explicitly aimed at all Karians. ${ }^{248}$ Delegates from various places were apparently invited to join in the panegyrics. ${ }^{249}$ Also, stamping the image of Zeus Labraundos on their coinage, used throughout the region, should be seen as a kind of mass-advertising in the technology of the day. The lack of Karian script, however, may raise questions as to how central this shrine actually was to Karian ideology. ${ }^{250}$ A fourth century вс plaque from Tegea, depicting the cult image of Zeus Labraundos with Idrieus and Ada worshiping it from aside, demonstrates the awareness on mainland Greece of the tight link between the god

247 Hdt. 5.119, quoted above.

248 I.Labraunda 53 , lines $1-3$. This is an imperial copy of a fourth century вС decree on the festivals at Labraunda, see also Piejko 1990, 147 no. 53.

249 I.Labraunda 67 (corresponding with I.Mylasa 8) is a heavily fragmented list of names, thought to be envoys to the festival, from the fourth century вС, inscribed on a stele found in front of the northeast anta of the temple. Unfortunately the origins of these people are unknown. I.Labraunda 72 is an imperial copy of a Hellenistic list of names, also thought to be envoys.

250 Karlsson and Henry (2009) discusses a Karian graffito, on a fourth century BC Attic gloss ring foot found at the fortification of Burgaz Kale, that shows similarities in Karian script from Sinuri-Kildara, Euromos, Stratonikeia, but not Mylasa. although a fourth century graffito, perhaps indicating that soldiers from across Karia helped guard the mountain shrine and passage. 
and the ruling dynasty. ${ }^{251}$ Yet the conscious epigraphic choice for Greek does not make Labraunda less Karian; instead it underscores the cosmopolitan aspirations of the Hekatomnids, even if there is much more evidence for regional involvement at the shrine. A fourth-century Panathenaic amphora, for example, was dedicated in the sanctuary with an inscription by a certain [Hyps] ikles from Herakleia, probably nearby Herakleia under Latmos. ${ }^{252}$ The East Propylon should also be seen in this Karian-wide context too, since it allowed formal entry to the sanctuary for pilgrims coming from the north, while the South Propylon served those arriving from Mylasa. ${ }^{253}$

Jonas Crampa is somewhat skeptical of the success of the promotion of Zeus Labraundos by the Hekatomnids, as the names appearing on inscriptions at Labraunda generally lack any ethnic designation and are hence probably Mylasan. ${ }^{254}$ One may, however, also argue that most of the prosopography at the sight dates to later periods and it does seem to be the case that as the bond between the sanctuary and Mylasa grew tighter and tighter, the scope of the sanctuary narrowed to Mylasa. However, it is also true that Zeus Labraundos's signature double-axe came to symbolize Karia, and that his cult was installed at other places in the region, ${ }^{255}$ but also abroad as a Karian-centered venue for 'expatriates', with examples in Piraeus, Athens, Cyprus and Egypt. ${ }^{256}$ We may lack solid evidence of an intensive involvement from wider regions in the festivals of Zeus Labraundos in the Hellenistic period, yet his cult was nevertheless broadly recognized as a Karian, not just Mylasan, affair, even though the epigraphic record at the sanctuary in this period is focused on the polis.

251 Now in the British Museum (Inv.no.1914,0714.1); Laumonier (1958), 24 n. 2.

252 Hellström (1965), 7-8, who argues his restoration of the name 'Hypsikles'. He considers that this was likely erected in a prominent place, e.g. as a votive offering in the newly built temple of Zeus (pers. comm. 23.03.2011).

253 Hellström (2009), 270.

254 Crampa, I.Labraunda p. 197 believes that except under the Hekatomnids, the cult of Zeus Labraundos was mostly local, noting the exceptions of someone from Alabanda who made a dedication, in I.Labraunda 37; also the name lists with perhaps envoys from Arlisses (I.Labraunda 67), Karyanda (I.Labraunda 72) and Bargylia (I.Labraunda 110).

255 Besides in Mylasa, Hornblower lists: Miletos, Herakleia under Latmos, Halikarnassos, Aphrodisias, see Hornblower (1982), 344. Laumonier includes Stratonikeia, Laumonier (1958), 6o-61. Several double-axes appear in the ceiling coffers at the sanctuary of Hekate in Lagina, and a small altar with a double-axe was found there as well (personal observation, 2009).

256 A third century stele for Zeus Labraundos in Piraeus, Laumonier (1958), 24 n. 2; the cult of Zeus Labraundos further spread of the cult to Kos, Cyprus (Zeus Labranios), and Limyra in Lykia, Athens (IG II ${ }^{2}$ 1271), Egypt; also Hornblower (1982), 345 n. 118 and 357 and Laumonier (1958), 6o-61. Iasos had a cult for Zeus Idrieus, I.Iasos $5^{2}$. 


\subsubsection{Civic Decrees}

Other than the architraval dedications, Mylasa figures little in the epigraphic record at Labraunda in the late Classical era. Two proxeny decrees from the fourth century granted foreigners free entry to Karia and the right to hold property, to import or export, to register in the phyle of their choice, and to

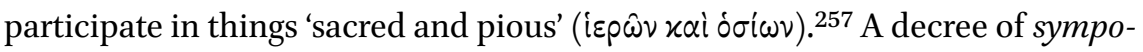
liteia between Pedasa and Latmos under the last satrap, Asandros, stipulated that it was to be inscribed at Labraunda. ${ }^{258}$ The fact that these decrees concerning the constitution of the Karian community were made public here at this remote mountain sanctuary demonstrates the regional political role that Labraunda occupied under the satraps. ${ }^{259}$

As stated above, however, this clearly changes in the Hellenistic era, when most of the inscriptions concern Mylasa. Center spot is of course the dossier of royal correspondence discussed previously concerning the conflicts between the priests and the polis, and ultimately confirming Mylasa's control over the sanctuary of Zeus Labraundos. ${ }^{260}$ A compelling tail to this dossier is an honorific decree for the strategos Olympichos, who was commemorated for his benefactions to the city. ${ }^{261}$ The inscription, found at Labraunda, calls for a statue of him being crowned by the Demos, to be erected in the agora, with an altar before it 'similar to the one of Maussollos in the sanctuary of Zeus Labraundos'.262 This decree directly frames Olympichos as a kind of neoMaussollos, yet clearly operating in the interests of Mylasa. The cultic honors given to the strategos are indicative of the complex process of democracy in the Hellenistic polis. Olympichos is honored with a procession, a sacrifice of two bulls, and a feast including the priests, the athletic victors of crowned games,

257 I.Labraunda 40, line 12, under Maussollos, granting immunity and import/export rights, and I.Labraunda 42, a decree made by the Macedonian Eupolemos, strategos in Mylasa towards the end of the fourth century, although the inscription itself is dated by Crampa to the second quarter of the third century, based on letter-forms.

$25^{8}$ Reger (2004), 151, with references. This inscription stipulates that it was to be placed in the sanctuary.

259 It is possible that corresponding decrees were also published in Mylasa, Halikarnassos, or another Karian port-of-entry, although none have been found thus far.

26 I.Labraunda $1-7$, discussed above.

261 I.Labraunda 49 and the new fragment I.Labraunda 134, discovered at the sanctuary in 2002 by Lars Karlsson and published in Isager and Karlsson (2008) and Isager (2011).

262 I.Labraunda 134 (Isager and Karlsson (2008)), lines 9-11 (translations by Isager and

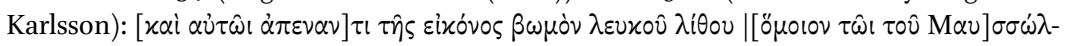

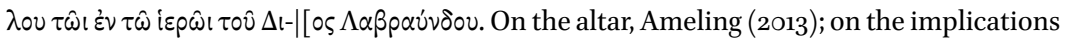
of cultic honors for Olympichos (and his wife Nikaea and their children), see Henry and Aubriet (2015), esp. p. 70o, also Aubriet (2012). 
and the magistrates. ${ }^{263}$ This is significantly to take place on 'the day on which the people regained its freedom and democracy,',264 highlighting the precarious balance between the dependency on the goodwill of local rulers such as Olympichos and the ability of the city to govern itself. ${ }^{265}$ Olympichos was to actually be crowned by the people of Mylasa as their benefactor, and this was moreover to be proclaimed during the gymnic games for Zeus Osogollis. Such public events functioned as mass advertising, generating common knowledge, and the inscription itself was clearly meant to serve as another coordinating mechanism, evident from the final clause: 'To ensure that it will be apparent to all how the people of Mylasa honors its benefactors, and in order to commemorate him [Olympichos] this decree shall be inscribed on stelai of stone and one of them placed in the sanctuary of Zeus Labraundos'.266 All of this indicates the space of negotiation between polis and strategos but especially demonstrates the new role of Labraunda as public podium for Mylasa, and how it became tightly integrated with its urban space, even though it was miles away from the center of town where the main events were staged.

Certain decrees on relations between Mylasa and other poleis also specifically stipulate that they be published in the sanctuary of Zeus at Labraunda. Decrees of isopoliteia with Miletos, and perhaps with neighboring Euromos, were also erected at Labraunda, ${ }^{267}$ as were honorific decrees by Mylasans for non-Mylasans (e.g. Romans) or vice-versa. ${ }^{268}$ An interesting but elusive

263 I.Labraunda 134, lines 14-17.

264 I.Labraunda 134, lines 12-14, listing the date as the 14th of the month Apellaios. A threeday truce follows next, during which the 'citizens and others' meet together wearing crowns. Events further included the singing of a hymn for Olympichos during the quadrennial Taureia, 'in the same way as for the city founders', lines $23-24$.

265 Two other inscriptions concerning Olympichos note the importance of democracy I.Labraunda 3 , line 30, and I.Labraunda 8B, lines 13-15.

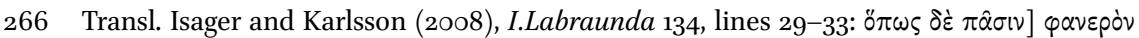

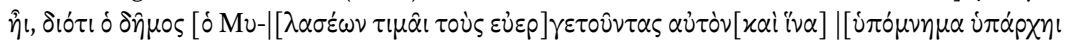

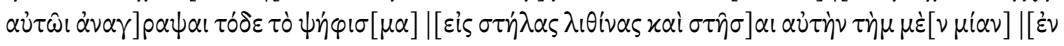

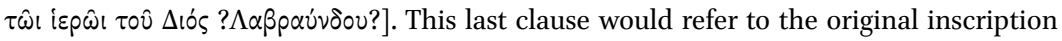
at the sanctuary; I.Labraunda 49 and 134 are copies from the second century вС, found in the area of the Roman baths. The site for the second inscription is unknown, presumably in the agora of Mylasa, or in the sanctuary of Zeus Osogollis, as with I.Labraunda 8, see also van Bremen (2016). On 'double inscriptions' and their placement, see also new research by Kamphorst (forthcoming), Drauschke (forthcoming).

267 I.Mylasa $\mathrm{T}_{51}$ for the isopoliteia with Miletos, this was to be erected in the sanctuaries of Zeus Osogollis and Zeus Labraundos. Isopoliteia with Euromos may have been intended in a fragment mentioning the neighboring polis, I.Labraunda 84; both inscriptions are dated to the late third century.

268 I.Labraunda 48 (second century BC); I.Labraunda 62 (c. 129 BC); and I.Labraunda 63 (early first century BC, based on lettering). 
example of an honorific monument concerns the exedra on the temple terrace, discussed above. Located at the eastern end of the temple terrace, this podium is estimated to have held nine statues. The inscriptions bear only the name of an individual, Demetrios, son of Python; Crampa dated them to the third century, based on the lettering. ${ }^{269}$ Other documents focused directly on internal Mylasan politics: two powerful examples include a fragment from the early Hellenistic period, inscribed directly on the southwest anta of the temple (Figure 3.6, Area B), referring to the restoration of justice and democracy at Mylasa after the downfall of tyranny, ${ }^{270}$ and a later second century inscription that bears the citizen's oath of Mylasa, inscribed in the east wall of the South Propylon (Figure 3.6, Area F). ${ }^{271}$ This oath, to safeguard the democracy of the polis at personal risk, was engraved at a place where everyone entering the sanctuary from Mylasa could see it and presumably internalize it with each visit. ${ }^{272}$ Although we do not know whether this oath was also posted in town, the very fact that it was inscribed here at Labraunda is perhaps more than anything else indicative of the very tight relationship between the sanctuary and the polis, and the highly urban function of this sanctuary. 273

Another example of the personal nature of these public documents is a decree related to property financing. Olympichos, while still in charge, initiated a mechanism of donating or selling private lands to a sanctuary and then leasing them back to the original owner with interest. ${ }^{274} \mathrm{He}$ dedicated some of

269 I.Labraunda $29 \mathrm{a}-\mathrm{c}$. The exedra was excavated in the 1940 s but is now published in Henry et al. (2014), 269, Fig. 28.

270 I.Labraunda 41, though fragmentary, shows the new political shift through references to the old tyranny and regulations allowing restoration to anti-Persian exiles. A certain Arlissis is mentioned - a Mylasan by the same name had been involved in a conspiracy against Maussollos and was sentenced by the Persian court to death, I.Mylasa 1; his family may have been seeking restoration of his name or some kind of compensation. Crampa dates it to the period shortly after Alexander's conquest.

271 I.Labraunda 47 (also Piejko 1990, 146-147) is the oath of the citizens of Mylasa, in which the reader promises to not to plot against democracy nor to allow anyone else to do so, and to be hostile to any unjust citizen or stranger; the reader invokes blessings to himself and his family through profit from his resources, land and its produce, cattle, children and houses, if he keeps his oath, and the opposite if he does not, This is similar in formula to the citizen's oath of Tauric Chersonesos but much compacter, IosPE $\mathrm{I}^{2} 401$; on both of these oaths in their spatial contexts, see Williamson (2013a).

272 The pivotal role of the South Propylon is discussed above and in Williamson (2013a) in connection with this inscription; also Isager (2011), 209.

273 E.g. Isager (2011), 209, who also supposes that another copy would have been inscribed in town or in the sanctuary of Zeus Osogollis.

274 I.Labraunda 8 and now Milas Museum Inv.no.2012/31a, discussed in van Bremen (2016). Olympichos dedicates all the lands that he purchased from Queen Laodike. Several later inscriptions from the sanctuary of Zeus Osogollis exhibit the various stages of this 
his lands to the sanctuary of Zeus Osogollis at Mylasa; the revenue was to be spent on the monthly festival. Olympichos hoped that his dedication would live in our memory and be kept'.275 Intending to set an example for others to follow, he further stipulated that this was to be inscribed in the sanctuaries of both Zeus Osogollis and Zeus Labraundos 'in the most conspicuous place.'276 Unfortunately we do not know exactly where this was perceived to be at Labraunda, since the stele was found in pieces in a later rubble pit; but part of a possibly joining fragment was discovered near the South Propylon, which was certainly a conspicuous place for those coming from Mylasa. ${ }^{277}$ A later addition to this inscription lists several subsequent land-lease transactions, with the lands described in meticulous detail. ${ }^{278}$ Although these transactions were all conducted through the cult of Zeus Osogollis in town, the fact that they were inscribed here underscores the urban role of Labraunda, and it also ties both of these sanctuaries together as central to Mylasa. ${ }^{279}$

unusual land-lease construction (misthosis) practiced in Mylasa, but also in Olymos; see Laumonier 1940; on Mylasa, see I.Mylasa 204, 207, 211, 212, 213, 214, 215, 216, 230, and 762, and Vol. 1, p. 74-76. I.Mylasa 212 gives insight into the financial construction (translation available in Blümel et al. (2014), no. 10. For an overview of the phases involved in this type of hereditary land-lease arrangement see further Chandezon (2003), 240-241; Dignas (2002a), 92; Descat and Pernin (2008), and now Pernin (2014), 401-445, esp. 422-427.

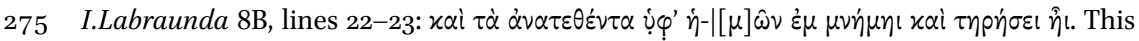
inscription was re-cut in the second century вС, when the land-lease construction at the sanctuary of Zeus Osogollis became quite popular, Dignas (2000), 123-124 and Virgilio (2001), 441; see also above.

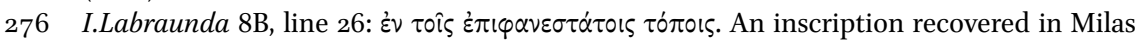
in 2011 (Milas Museum Inv.no.2012/31a) is a candidate for the version at the sanctuary of Zeus Osogollis, see van Bremen (2016). The sanctuary of Zeus Osogollis is located in modern Milas and was probably located within the urbanized area of ancient Mylasa, at least by Strabo's time (Strabo 14.2.23, see below); Rumscheid (1999c), 35 n. 6 o.

277 It should be noted that both inscriptions were second century вс copies of third century decrees - the location of the originals is thus completely unknown. Crampa furthermore considers the possibility that I.Labraunda 9, a fragment mentioning the priest of Zeus Osogollis as thanking Olympichos for a benefaction, may once have been part of I.Labraunda 8. See further below on the gateway as a 'conspicuous place' for dedications. Hellström also discusses the location of inscriptions and copies from later periods, Hellström (2009), 278-279.

278 See Horster (2010) on long lists of sacred lands as creating a 'virtual religious landscape' in the mind of the one viewing the inscription, further discussed in Chapter 4 on the sanctuary of Sinuri.

279 Reger alternatively suggested that in light of the recent events Olympichos personally "showed his colors with a major favor to the Mylasans' tutelary deity, and he rubbed Zeus Labraundos's nose in it by his order to advertise his generosity to a rival in a 'most prominent place' in that god's sanctuary," Reger (2010), 53. This is certainly an attractive idea, but I view this inscription more as an act of inclusion, enforcing Labraunda's active 
Sanctuaries certainly had an archival function, but the locations of inscriptions in ritual space were also often carefully selected for their visibility (Figure 3.6). ${ }^{280}$ The recurring designation 'in the most conspicuous place' implies not only that they were meant to be read, or at least seen, but also that there was a hierarchy of space. ${ }^{281}$ Certain places were perceived as more 'conspicuous' than others, no doubt depending on the use and flow of traffic at the sanctuary. The locations of a number of inscriptions and monuments are known, giving an idea of where some of these public spaces were in the sanctuary. If we sort them chronologically, we can observe a shift in focus, starting with the temple itself; 282 a statue for Hekatomnos was erected just northeast of the temple, perhaps even before the sanctuary's renovations under Maussollos, and nearby was another (later) statue for Ariarames, son of Maussollos (Area A on Figure 3.6). ${ }^{283}$ In this area a stele was erected in the mid-fourth century listing several names, probably of envoys, to the festivals. ${ }^{284}$ In the Hellenistic period the temple was still initially the medium for inscriptions. The earliest dates from the end of the fourth century and significantly celebrates the new post-Hekatomnid democracy of Mylasa and its return to justice; it was recorded on the southwest anta of the temple (Figure 3.6, Area B). Just below this was Olympichos's oath while the opposite northwest anta bore the Seleukid correspondence concerning the polis' control of the sanctuary (Figure 3.6, Area C). ${ }^{285}$ The elevation of the inscriptions in the reconstructions,

participation in the Mylasan sacred landscape, rather than one of exclusion. Also, I consider the promotion of the cult of Zeus Osogollis as more of a positive act in the general development of Mylasa after its freedom, rather than a negative one aimed at Labraunda.

28 o See also the discussions above on I.Labraunda 1-7, the royal correspondence concerning the rights to the sanctuary. For temple inscriptions in general, von Hesberg (2009) and Roels (2017).

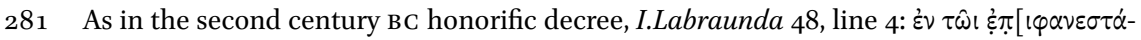
$\tau \omega \iota \tau$ $\delta$ $\pi \omega$ l. This phenomenon is briefly discussed, among others, in Mylonopoulos (2013), 136-137.

282 Signe Isager also discussed the significance of the locations of the inscriptions at Labraunda, Isager (2011), 204-214.

283 I.Labraunda 27 and 28 respectively; see Crampa p. 28-29 on Ariarames, also mentioned above.

284 I.Labraunda 67.

285 On the southwest anta: I.Labraunda 41 is the late fourth century вС inscription on the restoration of justice (see above), I.Labraunda 137 is the oath of Olympichos; see Henry and Aubriet (2015) and Carless Unwin and Henry (2016). On the northwest anta: I.Labraunda 1 and 3 give the correspondence between Seleukos, Olympichos and Mylasa on control over the sanctuary. The inscriptions on the antae of the temple are further elaborated on in Hedlund (2014) with a detailed reconstruction of the western elevation in Henry and Aubriet (2015), Fig. 4 and Carless Unwin and Henry (2016), Fig. 5 . 
at nearly five meters above the stylobate, might have precluded a casual reading, but would have ensured a good visibility of these documents that were so important for Mylasa.

The ensuing series of letters, between Olympichos and Philip v, were inscribed farther downhill, on the southern anta of Maussollos's andron (Figure 3.6, Area D). Though clearly official in function, this andron seems less obvious a candidate for the publication of such crucial documents, since most decrees were located higher up on the temple terrace. Labraunda's prime public space for democratic Mylasa seems to be the temple terrace, ${ }^{286}$ where several decrees, political and honorific, as well as monuments were set up, lining the area of the terrace which clearly functioned as public space (Figure 3.6, Areas E and G). ${ }^{287}$ This was not the only critical spot, however; the Mylasan citizen's oath was inscribed on an ashlar in the east wall of the South Propylon in the second century вС (Figure 3.6, Area F). ${ }^{288}$ This monumental entrance to the sanctuary was also the logical place for Antiochos III to post his letter to his troops, instructing them not to violate the sanctuary during their campaigns in the area. ${ }^{289}$ It may have been where Olympichos's exemplary dedication of lands was engraved, and where he was honored by Mylasa. ${ }^{290}$

286 On the date of the temple terrace and the North Stoa, see note 96 above.

287 A description of all of these is beyond the scope of this paper; monuments include the third century вс exedra at the east end of the temple terrace, facing south, I.Labraunda 29 (discussed above); a statue for Gnaius Domitius, son of Gnaius, at the northeast corner of the temple, I.Labraunda 62 (Carlsen (2011)); several honorific decrees inscribed on the walls of the stoa: I.Labraunda 11-12, 43-45 (concerning the Chrysaoric League); political or economic decrees: I.Labraunda 42 (by Eupolemos), 51 (on an economic-juridical matter), and 9o (donation of lands). Several honorific decrees, sacred laws or lists of names from the first century $\mathrm{BC}$ were found in the general area of the temple terrace: I.Labraunda $63,70-71,86,89,93$, establishing a trend in for this terrace that would continue until at least the second century AD (see Figure 3.6, Area G).

288 I.Labraunda 47, see above; on this inscription and its location see also Williamson (2013a).

289 I.Labraunda 46, from 203 BC; see above. Some name-lists were also inscribed here, as well as a decree involving Euromos, I.Labraunda nos. 68-69, 84 respectively. In the third century AD, a Roman officer inscribed at this gateway a promise of peace to the dwellers of the sacred lands, I.Labraunda 61 , proving its continued communicative function. Interestingly, no inscriptions have been recorded at the East Propylon. Westholm believes it to be contemporary with the South Propylon, Westholm (1963), 110-112, while Rumscheid dates it to the third quarter of the fourth century BC, Rumscheid (1994) ${ }^{1}$, 79-82.

290 I.Labraunda 8 (see above) and 9 respectively. I.Labraunda 49 is now also known to be an honorific decree, commemorating Olympichos for his benefactions to Mylasa, since a large corresponding fragment was found, Isager and Karlsson (2008) (I.Labraunda 134) this inscription was re-cut in the second century вС, and although neither fragment was found in situ, it is tempting to believe that they were located in the area of the South 
The inscription at the beginning of this discussion, concerning the honors awarded to Olympichos, was actually a copy made in the second century вС, a time when several of the inscriptions at the sanctuary were re-cut. ${ }^{291}$ Signe Isager and Lars Karlsson consider this phenomenon in light of the changing political climate following the Aristonikos wars when Karia, which had supported Rome, was joined to the new province of Asia. ${ }^{292}$ Isager and Karlsson note the installment of the honorific statue for the Roman benefactor Gnaius Domitius, son of Gnaius, at a key spot in the sanctuary (next to the temple and near area A on Figure 3.6), probably due to his role in "consolidating the status of Mylasa." ${ }^{293}$ Providing fresh and legible inscriptions at Labraunda of some of the most defining moments in the history of the polis was obviously the best means for Mylasa, in the shadow of Rome, to bolster "its political position to the outer world as well as the collective memory of its own inhabitants."294

This choice in fact underscores the kinds of decrees that Mylasa had inscribed at Labraunda. While other urban sanctuaries were often used as podia for public awards, Labraunda was more of a political space. The list in Table 3.1 shows the Hellenistic political decrees at Labraunda, five of which were issued by Mylasa and concern either the constitution, legal or economic matters, or external relations. ${ }^{295}$

Propylon, where I.Labraunda 9 was found (I.Labraunda 8 and 49 were found in a hole south of Andron C).

291 I.Labraunda 134 (=Isager and Karlsson (2008)), mentioned above. Inscriptions that were recut in later periods include: I.Labraunda 3(B) and 8, Olympichos's two letters of support for Mylasa, are both second-century вС copies of third-century originals, as was I.Labraunda 9 and 49/134, the honorific statue and decree for Olympichos by Mylasa; Boffo (1985), 244 believes that I.Labraunda 8 was copied in the context of the surge of land-leases for Zeus Osogollis. Other third-century inscriptions were re-inscribed in the imperial period, including I.Labraunda 1(B), the letter by Seleukos II, and I.Labraunda 10, the letter by the Chrysaoric League to Mylasa, and probably 88, a letter by an unidentified Hellenistic ruler to his governor. Virgilio sees this as evidence for Mylasa's continued need to justify their claims to Labraunda for various reasons, Virgilio (2001), 441.

292 Isager and Karlsson (2008), 49-50; Marek (1988), 302-303, believes Karia became part of the province of Asia only after the Mithridatic wars in the first century вс.

293 Isager and Karlsson (2008), 49-5o, discussing I.Labraunda 62, mentioned above. See also Carlsen (2011).

294 Isager and Karlsson (2008), 50. They observe that the inscriptions chosen for re-cutting primarily centered on Mylasa gaining its freedom, and its democracy.

295 Tables 3.1 and 3.2 are based on the dates and information given by Crampa in I.Labraunda. Given the fragmentary nature of many of the inscriptions found at the sanctuary, these lists can only suggest a general trend in the nature of the documents; see also Table 4.2 in Chapter 4 on the sanctuary of Sinuri. 
TABLE 3.1 List of political decrees at Labraunda from the Hellenistic period

\begin{tabular}{|c|c|c|c|}
\hline Inscription no. & Period & Issuing body & Concern \\
\hline I.Labraunda 41 & Late 4 th с вс & Mylasa & Democratic constitution \\
\hline I.Labraunda 42 & Early 3 rd с вс & $\begin{array}{l}\text { Eupolemos } \\
\text { (Macedonian } \\
\text { ruler) }\end{array}$ & $\begin{array}{l}\text { Grant of ateleia (tax exemp- } \\
\text { tion) for a Koan and proxeny } \\
\text { by Plataseis }\end{array}$ \\
\hline I.Labraunda 44 & Early 3 rd с вс & $\begin{array}{l}\text { Chrysaoric } \\
\text { League }\end{array}$ & $\begin{array}{l}\text { Immunity through } \\
\text { Ptolemy II }\end{array}$ \\
\hline I.Labraunda 84 & Early 2nd с вс & Mylasa & Concerns polis of Euromos \\
\hline I.Labraunda 47 & 2nd c BC & Mylasa & Citizen's oath \\
\hline I.Labraunda $5^{1}$ & $\begin{array}{l}\text { Early } 3 \text { rd с вс } \\
\text { or } 2 \text { nd }-1 \text { st с в }{ }^{a}\end{array}$ & Mylasa & Economic/legal matter \\
\hline I.Labraunda 89 & 1st c BC & Mylasa & $\begin{array}{l}\text { Decree on conditions in the } \\
\text { shrine? }\end{array}$ \\
\hline
\end{tabular}

a Date disputed: before 267 BC, van Bremen (2017), or "Republican period," Crampa in I.Labraunda II, pp. 75-77.

The honorific decrees set up here, listed in Table 3.2, were primarily for those who played an important part in the political situation of the polis. Here only half of the decrees were awarded by Mylasa, two for Olympichos, and two for Roman officials. The honors received by a Mylasan from a foreign polis (I.Labraunda 48) underscore the role that Labraunda had as political podium, with an emphasis on external relations, for the polis of Mylasa (see also Table 4.1 in the next chapter for a breakdown of the types of inscriptions from Labraunda in comparison with those from the sanctuary of Sinuri).

\subsubsection{Cult Iconography in Urban Contexts}

Mylasa clearly exerted itself at Labraunda, not only through the decrees discussed above, but through the occupation of the sanctuary by a large share of the urban body during the festivals. But there was another side to this relationship, the inclusion of Zeus Labraundos within the urban realm at the polis.

One important sign of the presence of Zeus Labraundos in the daily lives of the citizens are the dedications to Zeus Labraundos, often as altars, found in Mylasa and its environs. Some of these were actually inscribed to the god, 
TABLE 3.2 List of honorific decrees at Labraunda from the Hellenistic period

\begin{tabular}{|c|c|c|c|}
\hline Inscription no. & Period & Issuing body & Honorand \\
\hline I.Labraunda 43 & 267 вс & Chrysaoric League & $\begin{array}{l}\text { Ptolemaic } \\
\text { official - Apollonios }\end{array}$ \\
\hline I.Labraunda $29 \mathrm{a}-\mathrm{c}$ & 3 rd с вс & $?$ & $\begin{array}{l}\text { Demetrios, son of } \\
\text { Python? }\end{array}$ \\
\hline I.Labraunda 11 & $25^{\circ}-23$ о ВС & Syngeneia of Korris & Unknown \\
\hline I.Labraunda 12 & $25^{\circ}-230$ BC & Syngeneia of Korris & Unknown \\
\hline I.Labraunda 9 & Later 2nd с вс & Mylasa & Olympichos \\
\hline I.Labraunda 49/134 & Later 2nd с вс & Mylasa & Olympichos \\
\hline I.Labraunda 48 & 2nd с BC & Foreign polis & $\begin{array}{l}\text { Mylasan - Dionysios, son } \\
\text { of Timonax }\end{array}$ \\
\hline I.Labraunda 62 & c. $129 \mathrm{BC}$ & Mylasa & $\begin{array}{l}\text { Roman - Gnaius } \\
\text { Domitius }\end{array}$ \\
\hline I.Labraunda 63 & Early 1st с вС & Mylasa & $\begin{array}{l}\text { Roman - proconsul } \\
\text { Cornelius Lentulus }\end{array}$ \\
\hline I.Labraunda 93 & Early 1st с вС & (fragmented) & (fragmented) \\
\hline
\end{tabular}

while others carried a relief of the god, probably his cult image, or simply bore his characteristic double-axe (Figures 3.13-14). ${ }^{296}$

Coins were a very direct and ubiquitous way of broadcasting a bond between a deity and a city. The imagery, figure or face, sculpted on them is immediately associated with the party issuing the coin, whether polis or ruler, and on a relatively mobile object, circulating from hand to hand for a number of generations. Zeus Labraundos's close relationship with the Late Classical satraps is demonstrated by his appearance on issues of Hekatomnid coinage, beginning

296 I.Mylasa 314 is a marble altar, from the second century вС, with a relief of a double axe and

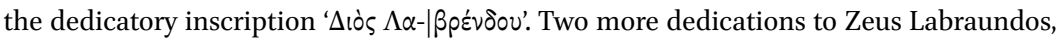
now in the Milas Museum, were discovered in the Uzunyuva excavations and published in Marek and Zingg (2018), 185, no. 27 by Demetrios, son of Thraseas, from the second century BC, and no. 28 by Demetrios, son of Poution, with the worn letters allowing only a rough dating to the Hellenistic period. Akarca also shows four more altars with reliefs of double-axes, later worked into walls in Milas, Akarca (1959), 40 n. 1 and Pl. XIX, nos. 1, 3, 4, 5. No. 3 on this plate, resembling a fountain head, may be the same object now located in the Bodrum Museum. Other dedications in Mylasa to Zeus Labraundos, but undated, are I.Mylasa 311 (votive altar), 312, 313. I.Mylasa 533 is a dedication from the Roman period. 


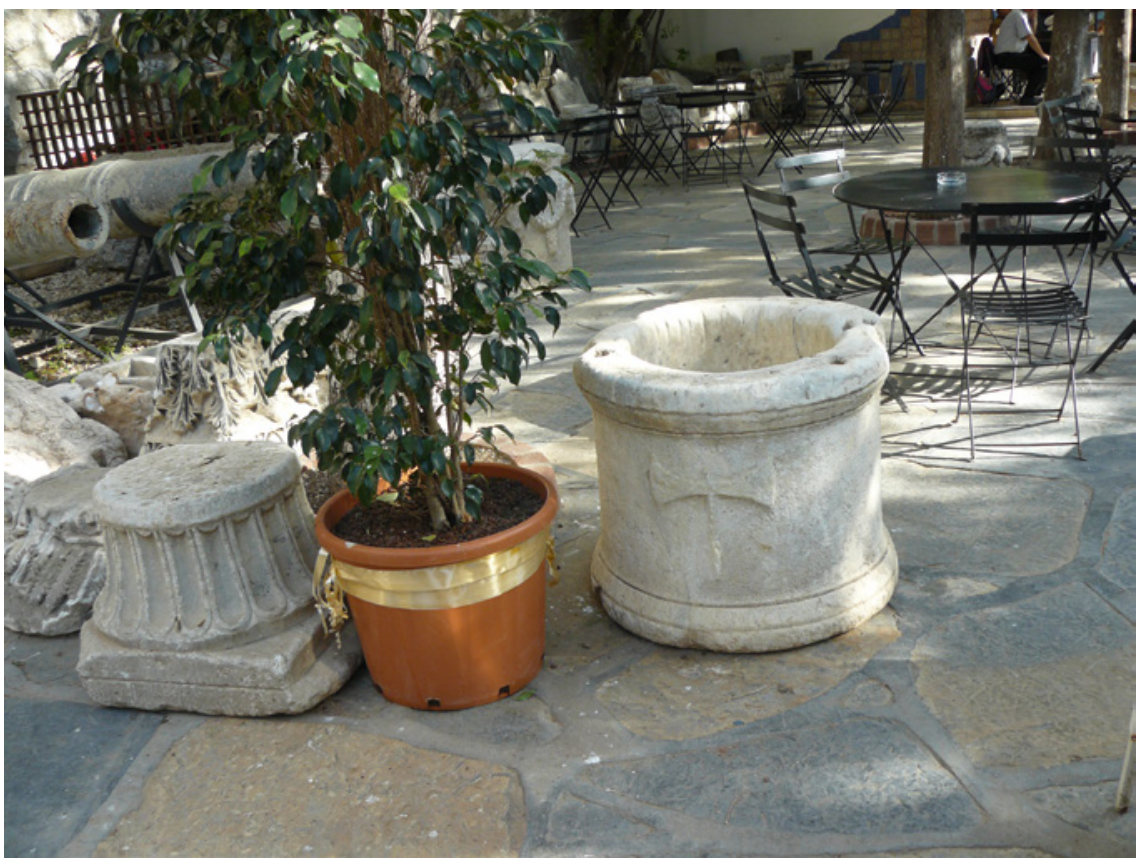

FIGURE 3.13 Round altar with double-axe, from Şeftalı Irın, southwest of Mylasa BODRUM MUSEUM OF UNDERWATER ARCHAEOLOGY, PHOTO AUTHOR 2009

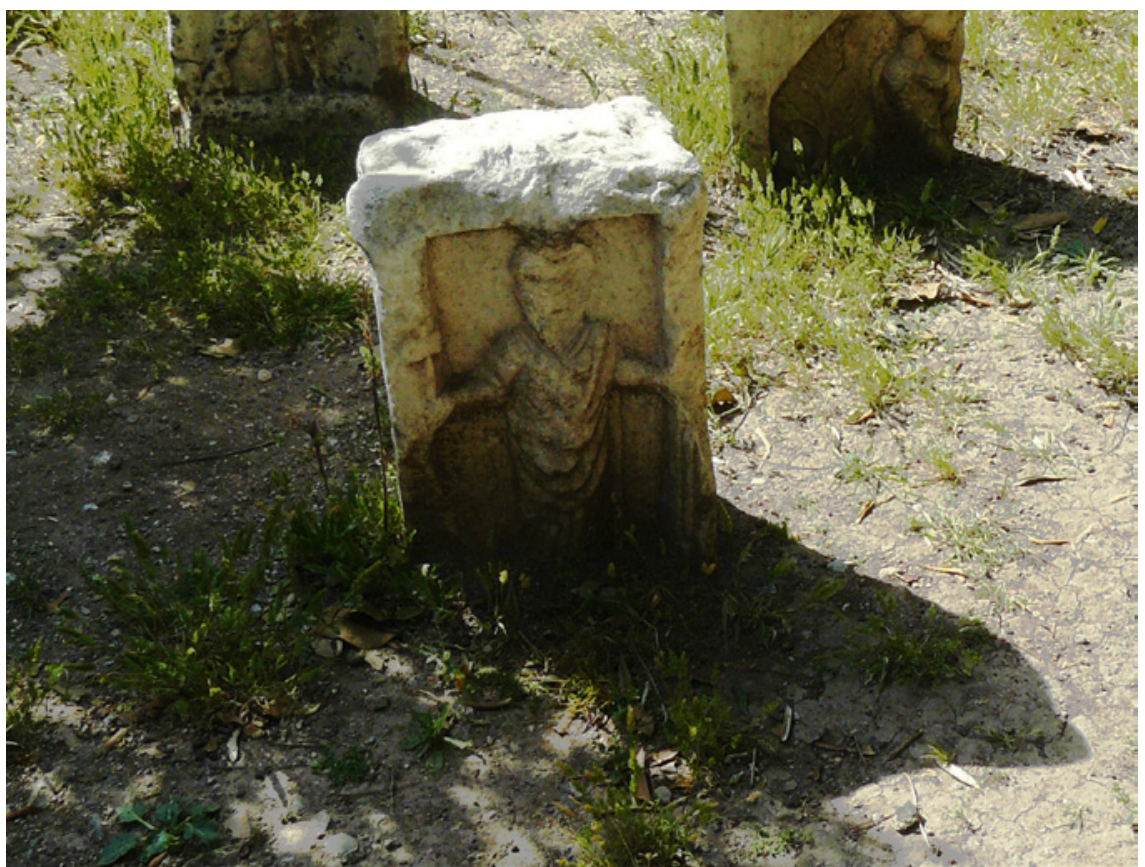

FIGURE 3.14 Small altar with Zeus Labraundos, probably Roman by analogy with Akarca 1959, Pl. XX, no. 3 
with Hekatomnos (Figure 3.15a).297 Zeus is shown on this silver tetradrachm striding to the right carrying his double-axe in his right hand over his shoulder, and his lance or scepter upright in his left; he wears a chiton covered with a himation which is drawn across his body and carried over the right arm. This was a specific portrayal of the god in action, rather than his static cult image which would have been the more usual portrayal of devotion to the god, as shown in the relief from Tegea, in which Idrieus and Ada are depicted worshiping at the side of Zeus. ${ }^{298}$ This relief shows Zeus with the double-axe over his right shoulder with the himation over his left arm, and the scepter in his left hand, as on the coinage; yet here the god is standing still and facing the viewer, with six large globular pendants across his chest, reminiscent of Ephesian Artemis. ${ }^{299}$ Perhaps depicting his cult image in the temple, this is more typical for the iconography of Zeus Labraundos on coinage from later imperial Mylasa, and altars like the one in the Bodrum museum (Figure 3.14b). ${ }^{300}$

Hekatomnos thus chose instead for an active representation of Zeus Labraundos on his coinage, and placed the strident god on the obverse, with a roaring lion on the reverse. Maussollos retained the image, yet placed Zeus Labraundos on the reverse of his coins. On the obverse, several bear the image of Apollo, poliad deity of Halikarnassos (Figure 3.15b), underscoring the tight connection between the cosmopolitan, coastal city and the inland, Karian sanctuary. ${ }^{301}$ Yet an interesting Mylasan issue carries instead Zeus Osogollis, with trident and eagle, on the obverse (Figure 3.15c). ${ }^{302}$ Zeus Labraundos clearly had connections with all of Karia, as did the Hekatomnids, whereas Zeus Osogollis was the primary deity of Mylasa. Placing these two emanations of Zeus on either side of his Mylasan coinage created a triangular relationship

297 On this coin type see Ashton et al. (2002b), 125-128.

298 Fourth century relief from Tegea, now in the British Museum (Inv.no.1914.7-14.1); see e.g. Gunter (1989), 96, with a good photo in Fig. 6; Carstens (2009), 93-94; Hellström and Thieme (1982), 32-33; Akarca (1959), 41-42, with a list of references in p. 41 n. 5; Laumonier (1958), 24 n. 2 and 64-66.

299 Laumonier discusses these at length in Laumonier (1958), 70-80, in connection with his discussion of the 'primitive' types of images of Zeus Labraundos.

300 Laumonier (1958), 70-83 discusses in detail a number of these images, which he believes are archaizing representations from imperial times; Zeus appears stiff and swaddled, protruding pendants on his breasts, and outstretched arms, holding the double-axe and lance, e.g. Akarca (1959), types 16.2 and 16.3, from the Hadrianic period. Euromos, however, also portrayed Zeus in this fashion on its coins from the second or first century BC, e.g. SNG Copenhagen 333 .

301 Pedersen (2009), 334-337; Konuk (2013).

302 This coin was part of the Pixodaros hoard, published by Hurter (1998) as Type B, and discussed further in Delrieux (1999), 36, and Ashton et al. (2002a), now Konuk (2013). 

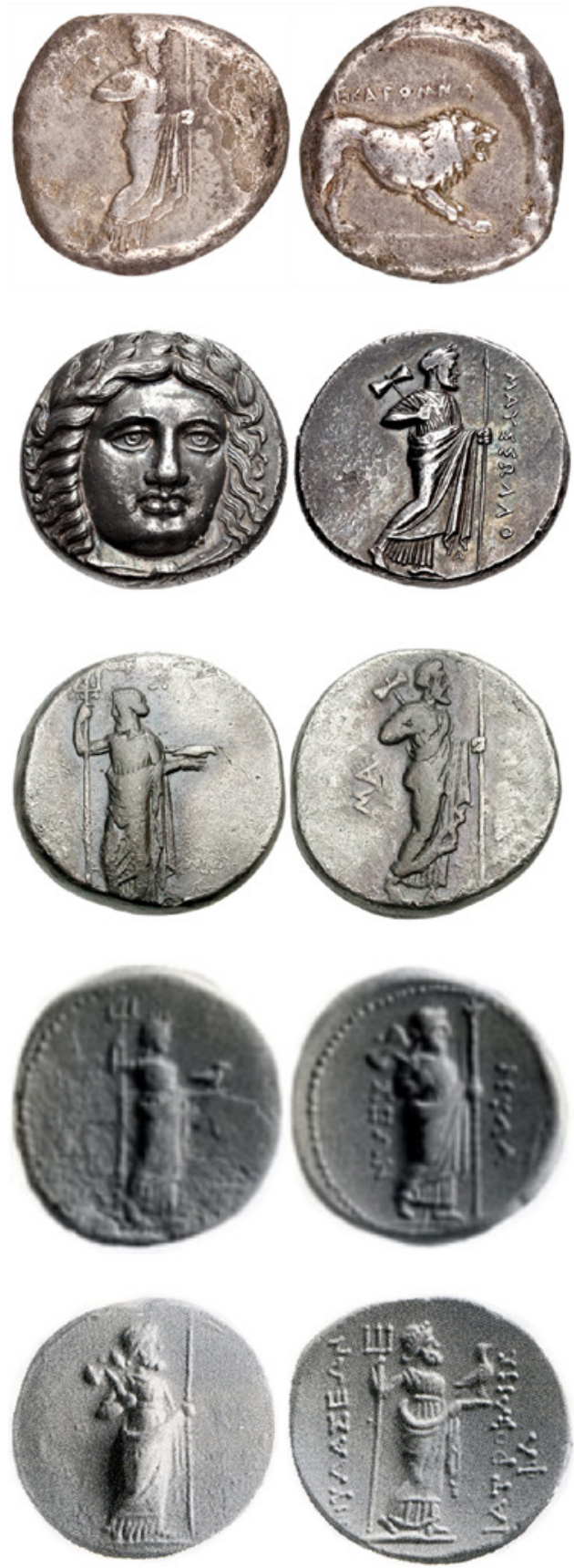

a. Hekatomnos. Silver Tetradrachm, c.380 BC BC

Obverse: Zeus Labraundos striding right, holding double-axe and scepter

Reverse: roaring crouching lion with EKATOMNOY, inside circular incuse.

Ashton et al. (2002), 125-128; Konuk (2013), 15

Type discussed in Delrieux (1999), 36, Plate 10, Fig. 2. Classical Numismatic Group,

e-auction 452, Lot 353: 18.09.2019

\section{b. Maussollos. Silver Tetradrachm, 370-360 BC}

Obverse: Apollo, laureate and facing $3 / 4$ right Reverse: Zeus Labraundos striding right, holding double-axe and scepter, small $A$ under his drapery, MAY $\Sigma \Sigma \Omega \wedge M O$ to right.

SNG von Aulock 2358 (this coin type). Type discussed in Delrieux (1999), 36, Plate 10, Fig. I.

Clossical Numismatic Group.

Auction Ex TritonX, lot 307: 10.01.2017.

c. Maussollos. Silver Tetradrachm, 377/6-353/2 BC

Obverse: Zeus Osogollis standing $3 / 4$ left, holding eagle and trident

Reverse: Zeus Labraundos striding right, holding double-axe and scepter, with MA.

Hurter 1998, Type B (this type). Type discussed in Delrieux (1999), 36, Plate 10 A-B.

Classical Numismatic Group.

Auction Triton XIII, lot 1320:05.01.2010

\section{d. Mylasa. Silver Tetradrachm, 3rd century BC}

Obverse: Zeus Osogollis standing right, holding eagle and trident

Reverse: Zeus Labraundos striding right, holding double-axe and scepter, with MYAA- $E E \Omega N$ on either side; within a circle of beads

Delrieux (1999), Group A no. IA, Plate 9 IA.

\section{e. Mylasa. Silver Tetradrachm, 3rd century BC}

Obverse: Zeus Labraundos standing right holding double axe (labrys) and scepter

Reverse: Zeus Osogollis standing right holding trident

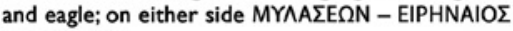
(magistrate).

Delrieux (1999), Group B no.4 (this type).

Classical Numismotic Group.

Auction Triton VII, lot 265: 01.2004

FIGURE 3.15A-E Hekatomnid and Mylasan coins showing Zeus Labraundos 
between himself and both deities, while forging a tight bond between his hometown Mylasa and the shrine at Labraunda.

Aşkıdil Akarca published two specimens of coins from Hellenistic Mylasa, with Zeus Labraundos and Zeus Osogollis on either side. ${ }^{303}$ She observed how faithful the Hellenistic issues of Mylasa were to this Hekatomnid type of Zeus Labraundos (Figure 3.15d). ${ }^{304}$ What she could not have known at that time was that even the combination with Zeus Osogollis was derived from the coins of Maussollos; the Pixodaros hoard, found in the 1970s in Bodrum (ancient Halikarnassos) and dating from the $340 \mathrm{OSC}$, contained two coins of this type. ${ }^{305}$ The primary difference, as Delrieux observes, is that Zeus Osogollis is turned around and facing right, much like Zeus Labraundos. ${ }^{306}$ This emphasizes the similarities between the two gods even more. Whereas Akarca had at her disposal only two specimens from the Hellenistic period depicting Zeus Labraundos, Delrieux was able to study another 11 tetradrachms and two additional didrachms, most of which were from a more recently discovered hoard (the 'Rhodian-Mylasian hoard'). ${ }^{307}$ Through close comparison with other coinage from this hoard, Delrieux believes all of the issues with Zeus Osogollis and Labraunda to have been dated from the second part of the third century вС; he relates the issues to the liberation of Mylasa by Seleukos II in c. 246 вс. ${ }^{308}$ Those with Zeus Osogollis on the obverse, like Maussollos coin, were likely the early issues in this group, but the others, with Zeus Labraundos on the obverse, were not far behind.

If Delrieux's dates are correct, then the issues may have been an attempt to consciously recall the coinage of Maussollos, in which both gods were combined. The early issues in fact show Zeus Labraundos on the reverse, embraced

303 Akarca (1959), 33 and nos. 9-10. No. 9 shows Zeus Osogollis on the obverse with Zeus Labraundos on the reverse (Delrieux (1999) Group A, specimen $1 \mathrm{~b}$ ), while no. 10 is the opposite (Delrieux (1999) Group B, specimen 6).

304 Akarca (1959), 33: "Leur source d'inspiration ce sont les monnaies des satrapes de Carie du IV ${ }^{\mathrm{e}}$ siècle, à tel point que la représentation de Zeus Labraundos est empruntée directement à ces monnaies. Dans le premier émission, Zeus Labraundos est une copie fidèle des monnaies comme sur celles-ci."

305 Hurter (1998), Type B (Pixodaros succeeded Idrieus as satrap in Karia, his coins are very similar to those of Idrieus, showing Zeus Labraundos on the reverse, with Apollo, the chief god of Halikarnassos on the obverse). The coin shown in Figure 3.15b represents a third specimen of Type B.

306 Delrieux (1999). Group A.

307 Delrieux (1999), 33-36.

308 Delrieux (1999), 42-45; these coins would then coincide with the Rhodian standard for tetradrachms. 


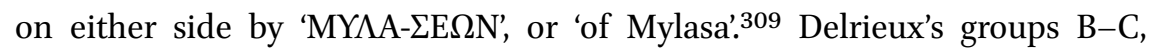
with Zeus Labraundos on the obverse and Zeus Osogollis on the reverse (e.g. Figure 3.15e) may then date from the success of Mylasa's claims to Labraunda; from this time it would not have been as necessary to 'label' the god as Mylasan, since that was now self-evident. Yet the overt associations with Zeus Osogollis remained; Zeus Osogollis was at this time being promoted as an important poliad god of Mylasa - associating the names of the magistrates with the more urban sanctuary probably made more sense. ${ }^{310}$ The perception of the gods as pairs is evident in a number of inscriptions, at times joined by Zeus Eleutherios. ${ }^{311}$

This association between Zeus Labraundos and Zeus Osogollis was also expressed in the bronze coins, in which the symbols of both gods were combined: the trident on one side, and the double-axe on the other. ${ }^{312}$ Reducing the presence of the deities to these symbols implied that everyone understood the references to the deities; for Zeus Labraundos this underscores the appearance of the double-axe as his 'logo', even though such hatchets were commonly associated with sacrifice. ${ }^{313}$ The double-axe is in any event found throughout Mylasa, as on the altar shown in Figure 3.14a-b, but also carved into walls in various places, such as the north gate of Mylasa, Baltalı Kapı (Figure 3.11). ${ }^{314}$ In fact, the double-axe became a highly successful emblem and is further found throughout Karia, appearing among others in a relief found at the sanctuary of Sinuri, in the ornamentation at the sanctuary of Hekate in Lagina, and in later representations of Zeus Panamaros, implying a direct association between these deities and Zeus Labraundos. ${ }^{315}$

309 Delrieux (1999), Group A, Pl. 9, specimen nos. 1A, 1B and 2.

310 The general Olympichos had dedicated some of his lands to Zeus Osogollis, with the proceeds explicitly designated to help pay for the festivals, I.Labraunda 8, see above.

311 E.g. I.Labraunda 6, lines 8-9 refer to Zeus Ososogollis, Zeus Labraundos and Zeus Eleutherios; Henry and Aubriet (2015), 695, also Debord (2001b). The priest of Zeus Labraundos, Hekatomnos, son of Ouliades, was often attested with the priest of Zeus Eleutherios, Euthydemos, son of Theoxenos, in land transactions in the later second century, e.g. in Olymos, I.Mylasa 801, 803, 814, 816B, and at Thraseas, I.Mylasa 207 and $207 \mathrm{~B}$.

312 Akarca (1959), nos. 22-26. Delrieux suggests that these were issued slightly later, at the end of the third and beginning of the second century, Delrieux (1999), 45.

313 See Laumonier (1958), 85-95 on the double-axe and its connotations as a general sacrificial instrument, not just in Karia but also on Krete.

314 Akarca (1959), Pl. XIX, figs. 1-5 include the altar in Fig. 13, and four more examples of the hatchet carved into walls. On Baltalı Kapı, Kızıl (2009), with images.

315 On the relief at Sinuri, see in I.Sinuri p. 14 and Pl. vil and below, Chapter 4; the appearance of the double-axe at Lagina is discussed further in Chapter 5 , and at Panamara in Chapter 6. 
In short, the monumentality of Labraunda and the expansion of its festivals went hand in hand with the shift at this mountain cult place towards a larger regional scope under the satraps, who explicitly opened the shrine to all Karians, inviting them to participate in the cult of Zeus Labraundos while acknowledging their power. After the Hekatomnids had passed, however, the focus at the sanctuary began to shift again as the polis gained ultimate control via Olympichos by the end of the third century Bс. Labraunda underwent a new phase as urban podium for Mylasa, just as Mylasa embarked on a new phase as an autonomous polis. The documents posted at the shrine, although fewer in number than at other Mylasan sanctuaries (e.g. the sanctuary of Sinuri, discussed in the next chapter), are highly political and typically concern the entire polis, such as the citizen's oath, and its external relationships with other political entities. Even the honorific decrees are for individuals who were somehow critical to the integrity of the political body, such as Olympichos, or Dionysios, honored here as a Mylasan by a foreign city. The polis left its stamp on the shrine by inscribing documents in places most obviously connected with Mylasa, e.g. at the south gateway or on structures with a view towards the town. The Hekatomnid design of the sanctuary appears to have been respected, even enhanced by the Doric stoa (Building $\mathrm{M}$ ) and the additional fountains. This may well have been part of a deliberate effort to recall the monumental power of the dynasty, as a 'memory theater' in Hellström's words. The polis also capitalized on Hekatomnid memory by recycling their imagery of Zeus Labraundos in its coinage, and if Delrieux's chronology is correct then this occurred around the time that Labraunda was contested space between the polis and the priests. Mylasa thus appropriated Labraunda as a public platform for its own goals, but in doing so appears to have made conscious use of the legacy of the Hekatomnids and mass media to propagate their claim to the sanctuary.

Interpreting Change in the Relationship between Mylasa and Labraunda

Out of all the sanctuaries in its chora, that of Zeus Labraundos was of particular importance to the Hellenistic Mylasa, given the considerable lengths to which the polis went in order to retain control. While this was clearly connected to the monumental heritage of the Hekatomnids, the changes at the sanctuary, reviewed above, as well as its geography allow for a deeper analysis of why this mountain sanctuary was so critical to the polis over a century after the passing of the dynasty. 
In order to do so it is helpful to take a step back and consider the situation in light of some of the more well-known models of relationships between poleis and remote major sanctuaries discussed in the first chapter. These models tend to focus on the distinction between town and countryside, with an emphasis on territorial borders. ${ }^{316}$ Shrines far from the urban center and near the border with the next community are typically designated as 'frontier sanctuaries'. As they rose to prominence, such sanctuaries are seen as marking critical spots in the political landscape that identify contested areas between neighboring communities. Following de Polignac, this reflects the need for a polis to establish territorial dominance in the face of a peer, neighbor, or rival community. ${ }^{317}$ Considering the physical and geographical data alone, it is tempting to interpret Labraunda as such a frontier shrine. Highly monumentalized and on a critical mountain pass at the northern edge of Mylasan territory, Labraunda was probably close to the natural borders of the poleis of Alinda to the north, and near the territory of Olymos to the west. Territory was surely a major concern to Mylasa, as witnessed by its aggressive and expansionist policies. However, besides the location itself, nothing at the shrine itself indicates that any of these borders were particularly worrisome for Mylasa. If anything, the inscriptions listing sacred lands belonging to Zeus Labraundos as being adjacent to those of Apollo and Artemis of Olymos speak for a patchwork landscape with fuzzy borders between the two poleis; in fact the landscape is depicted as belonging more to the gods than the political entities. Olymos was eventually absorbed by Mylasa, extending its territory even farther to the west. This probably happened in the third century already, meaning little need for Mylasa to use Labraunda to mark the western frontier at this point in time. ${ }^{318}$ Alinda, on the northern side of the mountain pass, seems to have figured little, if at all, on the political agenda of Mylasa.

Labraunda and its estates probably pre-date the formal organization of these poleis and their territories. The sanctuary would, however, have already occupied a central place among the local communities that were later incorporated into the poleis. This is a fundamental difference with the landscape of Archaic Greece addressed by the 'frontier' models. In Hellenistic Asia Minor,

316 E.g. Guzzo (1987); de Polignac (1995); Malkin (1996); discussed in Chapter 2.

317 De Polignac (1994) and (1995).

318 On the absorption of Olymos, Euromos, and Labraunda into Mylasa, see Cousin and Diehl (1898), 433-435, who place this in the mid-first century BC, as does Crampa in I.Labraunda, p. 25. Reger (2004), 164-168, however, dates the sympoliteia with Olymos in the third century BC; this view is finding more support, see LaBuff (2016), 109; van Bremen (2016); with the most compelling evidence in I.Labraunda 137, line 9, the 'Olymid Petra' discussed in Carless Unwin and Henry (2016). 
communities that evolved in alignment with the polis formula did so in a landscape that was already highly articulated and socially stratified. Mylasa is generally seen as the composite result of a synoikism of such local communities, and so when it later absorbed Olymos and Euromos, it was in a sense just taking this policy to the next step. ${ }^{319}$ Other than promoting and safeguarding the new treaties in stone, sanctuaries in these areas hardly seem to have been concerned with border issues. This is not to say that Labraunda did not figure in the territorial ambitions of Mylasa; it certainly did, but for other reasons than its proximity to a boundary with a neighboring polis.

Labraunda was itself contested space for a time between the priests and the polis, but it did not fall into limbo in the Hellenistic period as was once thought. ${ }^{320}$ Inscriptions and the ceramic record testify to a continued and intensive use that is now also reflected in the architectural developments. For all intents and purposes the monumental design of the Hekatomnids was left intact, but there were some significant modifications, including the three monumental fountains and the Doric stoa stretching across the Middle Terrace. ${ }^{321}$ These structures clearly served the public at large, providing them with extra water sources, additional shelter, and a protected view across the shrine and the Karian landscape below. One might interpret this as an 'opening up' of the facilities to a wider audience, letting a larger share of the population enjoy the amenities of the complex built by the legendary rulers, particularly if a large section was originally built as a royal palace. Pontus Hellström observed the general respect for the Hekatomnid shrine in later periods, evidenced by the care taken to preserve their dedicatory inscriptions; he even suggests that one of the architrave inscriptions may have been faked in the Hellenistic or Roman period to make it appear Hekatomnid. ${ }^{322}$ Working from the extant view of a complete standstill in building activity in the Hellenistic period, he asked whether this might have been “due to a decision to preserve Labraunda's

319 Local communities such as Beçin Kale, Gencik Tepe; Rumscheid (2010), 96-99, suggests the fourth century for the synoikism; Hornblower (1982), 69 n. 119 based on Radt (1969/70), 168-169 supposes the fifth century. On the development of Mylasa, see above at the beginning of this chapter.

320 Discussed above, also n. 115 .

321 Also the reuse of the Akropolis fortress and the multiple burials in the area testify to the intensive use of the site in the Hellenistic period, see Henry et al. (2014), 280-304; Henry et al. (2017), 15-221, 229-246; Henry (2017).

322 Referring to the less elegant nature of the architrave inscription on the 'Doric Building', Hellström (2009), 278-279. Also when the North Stoa was (re)built in the imperial period by the priest Poleites (I.Labraunda 23), he either reused or left intact Maussollos's dedicatory inscription (I.Labraunda 13). 
Hekatomnid memory theater?"323 Although it is now clear that some building activity did take place in the Hellenistic period, this question still merits consideration. The prime sanctuary of the legendary Karian rulers with its imposing architecture would certainly have evoked the ancient power of its builders, lending authority to those now in control. ${ }^{324}$

With its corporeal presence and ontological imminence, architecture has a special capacity to trigger the imagination of the past while retaining a functional use in the present. Michael Guggenheim examined architecture and memory through the lens of Actor-Network Theory, developed by Bruno Latour. ${ }^{325}$ In this theory, objects are inherently connected to time, and thus function as actors in a complex network of associations, most of which are built of memories. ${ }^{326}$ Objects have a way of 'conflating' time, by bringing the past immediately into the present, thereby imposing memories and connections onto human sensory perception. This is why they are sometimes intentionally isolated, e.g. in museums or laboratories, in order to 'stabilize' these networks, and more typically to isolate a particular network of associations from contamination by others. ${ }^{327}$ Buildings, however, are much more complex since they contain multiple associative networks that cannot be 'stabilized' they are continuously in use and inherently possess multiple temporalities all at the same time. ${ }^{328}$

323 Hellström (2009), 278; I explore this further in Williamson (2013d). The term 'memory theater' is used here as a place where memories of the past are combined with performances of the present, rather than as a strict mnemonic device as Giulio Camillo's 'Memory Theater', discussed in Yates (1966), 129-172.

324 The only negative tone at the sanctuary regarding the satraps is the very early Hellenistic inscription celebrating Mylasa's 'return to justice' after the downfall of the 'tyrants', I.Labraunda 41, dated to the late fourth century вС.

325 See Chapter 2 on the Actor-Network Theory, Latour (1987) and (2005); and Middleton and Brown (2005).

326 Guggenheim (2009), 41-43, this also may be the exception that proves the rule.

327 Guggenheim (2009), 41: "The stabilization of a network by enrolment is called blackboxing, a process whereby actants are stabilized in their use and meaning. At the same time, enrolment and black-boxing change the actants that are enrolled. What is called truth in science for ANT is nothing other than the stabilization of networks."

328 A good example is given in Guggenheim (2009), 46-47: "To use a building always means to use it partially, to use it in the presence of others and to interact with others in, through and with the building. The multiplication of uses creates networks that are outside of anyone's control, and specifically outside the control of any functional system. For example, while a tourist might stand in front of the Villa Savoye and look at it as an artwork, the inhabitant may be inside just preparing breakfast, while the plumber fixes the heating system and a restorer analyses the composition of the walls. All these uses may exist alongside each other, but they may even interact in all kinds of unexpected ways." 
What this theory allows us to do at Labraunda is to view the buildings as 'actors', creating and recalling all kinds of memories and associations at the same time. Using the sanctuary as a 'memory theater' does not mean that it was turned into a 'museum'. The architecture at Labraunda may have been preserved, but its associative networks were not stabilized in any way, nor could they have been if we believe Guggenheim - the sanctuary continued to be the center for festivals and ritual performances from generation to generation. The inscriptions from the third and second centuries, virtually the only additions to the sanctuary besides the fountain house, reiterate its ongoing use. They demarcated the ritual 'concentric' spaces at the sanctuary, showing that it was used in much the same way as the Hekatomnids had designed, while accentuating the areas that were particularly important to Mylasa, i.e. the nodes in the 'linear' space that joined the sanctuary with the polis: the 'framed' view of the polis from the andrones, and the South Propylon, the hinge at the end of the sacred road from Mylasa. The Hellenistic polis thus left its stamp on the Hekatomnid design of the sanctuary. Rather than being a question of passive finances or political inertia, architectural restraint was instead a way of actively tapping the ancient Hekatomnid associations to underscore the intrinsic authority of the sanctuary, and especially to highlight the polis as legitimate heirs of this landscape of power. ${ }^{329}$

The coinage from Hellenistic Mylasa reinforces this interpretation. The Hekatomnid image of Zeus, striding forward with his double-axe over the shoulder (Figure 3.15), was visually 'cited' in the imagery on the coins from the latter part of the third century (following Delrieux's chronology). Labraunda was contested space in this period, and reproducing this image of the god that had become familiar throughout Karia would have been another way for the polis to stress continuity with the Hekatomnid period. Copying Maussollos's coinage, with Zeus Osogollis on one side and Zeus Labraundos on the other, would furthermore have engaged the associative 'network' of the satraps' coins, creating an immediacy of the ancient rulers in the present day. It also would have established a link between the satrap who built much of the sanctuary and the polis that was now administering it. Finally, using the coinage with both figures of Zeus would have recalled the ancient connection between the two deities themselves, Zeus Osogollis in the city and Zeus Labraundos in the countryside, both symbolizing Mylasa.

Yet it is significant that the polis did not make exact replicas of the Hekatomnid coins; they made Zeus Osogollis look more like Zeus Labraundos, reversing his direction (but not changing which hands held what); some issues

329 See Williamson (2013d). 
were 'crowned' with a circle of beads, but most important, the name of the Hekatomnid ruler was replaced by that of the polis. Much like the sanctuary architecture, the coinage is about preserving the Hekatomnid past, but it is even more about using it to legitimate the present authority of Mylasa. Different from architecture, however, is the ubiquity and mobility of coins. Their mass-production qualifies them in the jargon of the Actor-Network Theory as 'immutable mobiles', objects that travel from one 'functional system', to the next, accumulating webs of associations along the way. ${ }^{330}$ With their capacity for mass-advertising, these coins are part of the 'rational ritual' process, ${ }^{331}$ mediatizing the message along one of the most efficient networks imaginable, that of trade, hand-to-hand. But the message encoded in the coins relied on the background knowledge of the recipient, and Mylasa was no doubt counting on the effectiveness of the networks of associations already created by the Hekatomnids for their success with these coins. They were the ones who made the image of Zeus Labraundos commonplace throughout Karia. That the double-axe practically became a logo for Karia for centuries to come is thanks to their initiative of drawing the focus of the community to the cult at Labraunda.

Preserving Hekatomnid architecture and re-using their iconography are two indirect ways that Mylasa tapped the power of the ancient rulers that had unified Karia. The effectiveness of this may be seen in the onomastics of Hellenistic Mylasa. In her study on the frequency and type of Karian personal names in the Hellenistic period, Daniela Piras found that the otherwise wholesale shift towards Greek names was mitigated primarily in Mylasa, where there was a sudden circulation of Karian names that were almost exclusively Hekatomnid. ${ }^{332}$ Although this may simply be homage to a shared ancestry, it seems more likely that it reflects a renewed interest in the powerful rulers of the previous era, particularly when taken together with the traditional iconography in the coinage and the architectural 'preservation' at Labraunda. If so, this trend would be a remarkable contrast with the anti-tyrant sentiments that surface through an inscription at Labraunda, dated to late fourth century, i.e.

330 Latour (1987), 226-227. Guggenheim applies an inversion of Latour's term, "mutable immobiles," to architecture, to underscore its singularity and yet changeability of meanings, Guggenheim (2009), 45-48.

331 Chwe (2001), esp. 21-22, on ritual as "saturation advertising," in effectively creating common knowledge.

332 Piras (2010), 226-229, discusses the surge of Karian names such as Hekatomnos, Pixodaros, or Artemisia, given to children whose fathers often had Greek names. Aubriet (2013) discusses onomastics as an expression of a 're-Karianization' of Mylasa. 
the period just after the Hekatomnids had passed; this fragmentary inscription mentions a return to justice following the 'tyranny' of the dynasty. 333

What Mylasa was doing at the sanctuary and with the image of Zeus on its coins perfectly coincides with its stance in the conflict with the priests over Labraunda. The Hekatomnids were the ones who 'created' both Mylasa and Labraunda by radical redesign - the one as a new urban center and the other as the religious center of Karia. It is logical that the Mylasans would see themselves as the rightful heirs of this particular Hekatomnid legacy, and therefore guardians of the sanctuary, just as the priests did by ancestral rights. The main difference was that Mylasa had the institutions of the polis - the legal system, the festivals, and the advertising capacity of coinage - at its command to enforce its role and leverage the symbolic capital of the deity. ${ }^{334}$ The irony, however, is that the newly independent polis that once referred to the Hekatomnids as 'tyrants', nonetheless relied on their fame and ongoing popularity to legitimate its own authority, both at home and in the region, while at the same time participating in the wider Greek world as an autonomous and democratic polis.

The central role of Labraunda in Hekatomnid ideology thus explains in part why the sanctuary was so important to Mylasa more than a century later - the cult was necessary to the symbolic shaping of the newly independent polis. But another reason for the Mylasans to be so interested in this sanctuary and its design may well coincide with the same reason that the Hekatomnids chose this sanctuary in the first place - the power of the place. Location is vital to Labraunda. Besides being along a main mountain pass, at a critical spot that intersected the spheres of different communities, it is also on a commanding height with a view towards most of southwest Karia. The Hekatomnids surely appreciated the superb panoramic view, as well as the tactical advantage of the location. As mentioned above, sightlines emphasized by architecture tend to collapse space between objects, making them feel closer than they actually are because they have mentally become more comprehensible. ${ }^{335}$ The antiquity of a site, combined with oral and inscribed traditions, serve to further heighten

333 I.Labraunda 41, probably from the southwest anta of the temple. Crampa interprets the inscription as a decision of democratic Mylasa "to alter regulations or conditions from the earlier 'tyranny' by juridical mode of action," see his commentary in Volume II, p. 41. See further Williamson (2013d).

334 Bourdieu (1986).

335 Ellard (2009), 264 "If the parts of our brain that deal with space have strong preferences for enclosed views, and if we patch together a mental collage of space by combining these views, then any time a builder erects a wall, he is influencing our conception of the spaces in which we live." 
its awareness and seeming proximity, thus foregrounding the place. ${ }^{336}$ Metrical distance aside, Labraunda felt very near to Mylasa. The windows in the andrones further emphasized the connection as they literally 'framed' the view; the central object within the frame is of course Mylasa and its landscape. This was surely not lost on the Hellenistic polis.

This mountain sanctuary of Zeus, the supreme deity, had little to do with territorial boundaries, but quite a bit with territorial domination, given the visual supremacy of the location. The sanctuary not only afforded a sweeping view of the entire region, its monumentality acted as a landmark, or a beacon of Hekatomnid, and later Mylasan, presence. Labraunda, designed in the Late Classical period by and for the satraps, worked equally well for the Hellenistic polis. The sanctuary became urban space, in which the identity of the polis in the region was central. Labraunda played a critical role in both the territorial and symbolic shaping of the polis, two critical stages in the construction of 'regional' identity as modeled by Paasi. ${ }^{337} \mathrm{~A}$ third stage is that of institutionalism, and this is one of the reasons that it was so important to the polis to make the priesthood conform to its perception of the institution of that office, since this was a critical post in ensuring that the needs of the polis were streamlined with the resources of the sanctuary, especially its symbolic capital. This symbolic capital, through the Hekatomnid heritage at the sanctuary and the power of its location in the landscape, was apparently for Mylasa the key to its establishment in the region, the fourth stage in the process of forming identity. This stage is typically associated with external recognition, yet this is an aspect which the sanctuary already possessed - by overlaying the identity of the god with that of the city, Mylasa was able to ride in the slipstream of this recognition.

The festival of Zeus Labraundos, in the heights of Karia, had thus become a central focus for the cohesion and common identity of the Mylasans, who originated from different subdivisions through which they celebrated their more local and popular identities, as the next case study will show.

336 Kantner (2008), 58-59, discusses the role of cultural memory in defining identities in landscape archaeology, using as an example the work done by Stewart and Keith on Inuit oral histories and archaeological places in northern Canada, showing how "places imagined as 'traditional' are 'foregrounded' in the landscape," based on the work of Stewart et al. (2004); see Chapter 2.

337 Paasi (2009), 134-136, discussed above in Chapter 2. 